\title{
EFEITO DA SÍLICA NANOESTRUTURADA \\ SBA-15 NA APRESENTAÇÃO ANTIGÊNICA E NA RESPOSTA \\ IMUNE
}

Tese apresentada ao Programa de PósGraduação em Imunologia do Instituto de Ciências Biomédicas da Universidade de São Paulo, para obtenção do Título de Doutor em Imunologia. 


\section{EFEITO DA SÍLICA NANOESTRUTURADA \\ SBA-15 NA APRESENTAÇÃO ANTIGÊNICA E NA RESPOSTA \\ IMUNE}

Tese apresentada ao Programa de Pósgraduação em Imunologia do Instituto de Ciências Biomédicas da Universidade de São Paulo, para obtenção do Título de Doutor em Imunologia.

Área de concentração: Imunologia

Orientador: Dr. Osvaldo Augusto Sant'Anna 
DADOS DE CATALOGAÇÃO NA PUBLICAÇÃO (CIP)

Serviço de Biblioteca e Informação Biomédica do

Instituto de Ciências Biomédicas da Universidade de São Paulo

reprodução não autorizada pelo autor

\section{Carvalho, Luciana Vieira.}

Efeito da sílica nanoestruturada SBA-15 na apresentação antigênica e na resposta imune / Luciana Vieira Carvalho. -- São Paulo, 2010.

\section{Orientador: Osvaldo Augusto Brazil Esteves Sant'Anna.}

Tese (Doutorado) - Universidade de São Paulo. Instituto de Ciências Biomédicas. Departamento de Imunologia. Área de concentração: Imunologia. Linha de pesquisa: Adjuvantes imunogenicidade.

Versão do título para o inglês: Effect of SBA-15 nanostructured in antigen presenting and immune response.

Descritores: 1. Adjuvante 2. Sílica mesoporosa SBA-15 3. Células apresentadoras de antígenos I. Sant'Anna, Osvaldo Augusto Brazil Esteves II. Universidade de São Paulo. Instituto de Ciências

Biomédicas. Programa de Pós- Graduação em Imunologia III. Título. 


\section{UNIVERSIDADE DE SÃO PAULO}

Programa de Pós-Graduação Interunidades em Biotecnologia

Universidade de São Paulo, Instituto Butantan, Instituto de Pesquisas Tecnológicas

Candidato(a): $\quad$ Luciana Vieira Carvalho.

Título da Tese: $\quad$ Efeito da sílica nanoestruturada SBA-15 na apresentação antigênica e na resposta imune.

Orientador(a): $\quad$ Osvaldo Augusto Brazil Esteves Sant'Anna.

A Comissão Julgadora dos trabalhos de Defesa da Tese de Doutorado, em sessão pública realizada a .................., considerou
( ) Aprovado(a)
( ) Reprovado(a)
Examinador(a): Assinatura:
Nome:
Instituição:
Examinador(a): Assinatura:
Nome:
Instituição:
Examinador(a): Assinatura:
Nome:
Instituição:
Examinador(a): Assinatura:
Nome:
Instituição:
Presidente: Assinatura:
Nome:
Instituição:




\section{CERTIFICADO}

Certificamos que o Projeto intitulado "Estudo experimental do efeito adjuvante da sílica nanoestruturada SBA-15 na apresentação antigênica e resposta à vacina para hepatite $A^{\prime \prime}$ protocolo $\mathrm{n}^{\circ} 356 / 06$, sob a responsabilidade de Osvaldo Augusto Sant'Anna e Luciana Vieira Carvalho está de acordo com os Princípios Éticos na Experimentação Animal adotado pelo Colégio Brasileiro de Experimentação Animal (COBEA), e foi aprovado pela COMISSÃO DE ÉTICA NO USO DE ANIMAIS DO INSTITUTO BUTANTAN (CEUAIB) em reunião de $13 / 02 / 2007$

A CEUAIB autorizou a(s) mudança(s) solicitada(s) pelo pesquisador, ou seja, um aditivo para espécie de camundongos e alteração na vigência do projeto.

\begin{tabular}{|c|c|c|}
\hline Vigência do Projeto: & $\mathbf{N}^{\circ}$ de animais/espécie & ADITIVO \\
$03 / 2007-12 / 2010$ & 50 camundongos HIII & 50 camundongos $\mathrm{Balb} / \mathrm{c}$ \\
Laboratório de & 50 camundongos LIII & \\
Imunoquímica & 120 camundongos Balb/c & \\
\cline { 2 - 3 } & &
\end{tabular}

São Paulo, 16 de agosto de 2010.

De acordo:

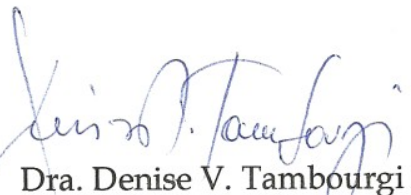

Dra. Denise V. Tambourgi Presidente da CEUAIB

Dr. Otávio Azevedo Mercadante

Diretor do Instituto Butantan 


\section{Certificado}

Certificamos que o protocolo registrado sob $\mathrm{n}^{\circ} 012$ nas fls. 42 do livro 2 para uso de animais em experimentação, sob a responsabilidade de Osvaldo Augusto B.E. Sant'Anna Coordenador(a) da Linha de pesquisa "Estudo experimental do efeito da silica nanoestruturada SBA-15 na apresentação antigênica $e$ resposta a vacina para hepatite $A^{\prime \prime}$ do qual participou(aram) o(s) alunos Luciana Vieira Carvalho e a pesquisadora Rita de Cássia Ruiz está de acordo com os Princípios Éticos de Experimentação Animal adotado pelo Colégio Brasileiro de Experimentação Animal (COBEA) e foi aprovado pela COMISSÃO DE ÉTICA EM EXPERIMENTAÇÃO ANIMAL (CEEA) em 27.02.2007.

São Paulo, 27 de fevereiro de 2007.

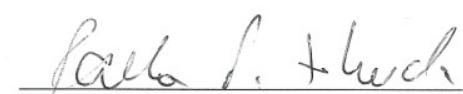

Prof. Dr. CARLOS PELLESCHI TABORDA Vice - Coordenador da CEEA - ICB/USP

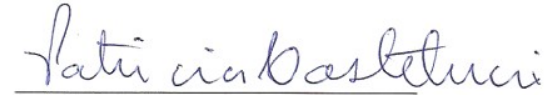

Profa. Dra. PATRÍCIA CASTELUCCI

Secretária da

CEEA - ICB/USP 


\section{UNIVERSIDADE DE SÃO PAULO}

INSTITUTO DE CIÊNCIAS BIOMÉDICAS

Cidade Universitéria "Armando de Salles Oliveira"

Av. Prof. Lineu Prestes, 2415 - cep. 05508-000 São Paulo, SP - Brasil

Telefone :(55) (011) 3091.7733 - telefax : (55) (011) 30917438

e-mail: cep@icb.usp.br

Of.CEUA.39.10

$\mathrm{NOSC} / \mathrm{mcgn}$

São Paulo, 23 de julho de 2010.

REF.: Protocolo $\mathrm{n}^{0} \mathbf{1 2} / \mathbf{0 7 .}$

"Estudo experimental do efeito da sílica nanoestruturada SBA-15 na apresentação antigênica e resposta a vacina para hepatite $A^{\prime \prime}$

Prezado Professor,

Informo que a sua licença para uso de animais em experimentação, constante no protocolo em epígrafe, foi prorrogada até 27.02.2013.

Reitero que havendo alteração de metodologia e inserção de novos alunos ao projeto de pesquisa vinculado à referida licença a CEUA/ICB deverá ser informada.

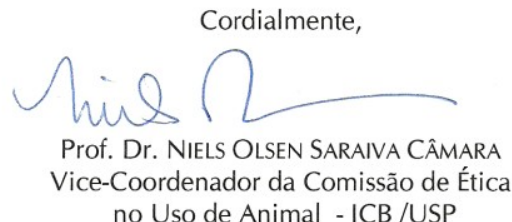

Ilmo.Sr.

Prof Dr. Osvaldo Augusto B.E. Sant'AnNa

Departamento de Imunologia

Instituto de Ciências Biomédicas - USP 
Aos meus pais, Sergio e Solange, e aos meus irmãos pelo amor, amizade, dedicação, incentivo, apoio constante e essencial para a realização de todos os meus projetos. 


\section{AGRADECIMENTOS}

Aos meus pais que me apresentaram o real valor da vida e com suas orientações e ensinamentos me conduziram a conclusão de mais um objetivo. Obrigada pelo amor, carinho e por estarem sempre ao meu lado, me aconselhando, estimulando, ajudando a optar pela melhor direção e comemorando com as minhas conquistas.

Ao Prof. Dr. Osvaldo Augusto Sant'Anna pela orientação, incentivo e pelos constantes e preciosos ensinamentos. Meu eterno agradecimento e admiração.

À Dra. Eliana Faquim de Lima Mauro pela colaboração no planejamento e realização dos experimentos, interpretação dos resultados e pela oportunidade de realização de parte deste trabalho no Laboratório de Imunopatologia do Instituto Butantan - IBu.

À Dra. Rita de Cássia Ruiz pela cooperação nos experimentos com macrófagos.

À Dra. Jacqueline F. Jacysyn pelo auxílio nas leituras e interpretações das análises realizadas no citômetro de fluxo.

À Dra. Márcia C. A. Fantini do Instituto de Física da USP e ao Dr. Jivaldo Matos do Instituto de Química da USP pelo auxílio na interpretação físicoquímica e fornecimento da sílica SBA-15, objeto central desta tese.

À Dra. Denise Vilarinho Tambourgi pela oportunidade de realização deste trabalho no Laboratório de Imunoquímica - IBu.

À Eliana Blini Marengo, Karina Scaramuzzi pelo apoio e sugestões preciosas para a finalização desse trabalho. Obrigada pela amizade e companheirismo! 
Ao meu amigo Estevam José Baldon pela constante ajuda e auxílio nas análises estatíticas e todos os assuntos relacionados ao tema Informática.

Às minhas amigas Alessandra Veloso de Melo e Míriam Aparecida Silva pelas palavras de conforto, incentivo e pela amizade.

Às companheiras do Laboratório de Imunopatologia, Sandriana dos Ramos Silva, Bruna Cristina Favoretto, Priscila Andrade Ranéia e Renata Ricardi pela receptividade e ajuda.

Aos técnicos do Biotério Edson Luiz da Silva e Severino Ramos da Silva pelo precioso auxílio.

À todos os colegas e funcionários do Laboratório de Imunoquímica pelo convívio, amizade e apoio, enfim, por fazerem com que tudo se tornasse mais fácil e por torcerem para que tudo corresse bem.

Aos funcionários da Biblioteca pela revisão textual e suporte de informática destas diretrizes.

À Fundação de Amparo à Pesquisa do Estado de São Paulo (FAPESP) pelo suporte financeiro.

Ao Laboratório Cristália pela colaboração determinada e efetiva. 
"Para realizar grandes conquistas, devemos não apenas agir, mas também sonhar; não apenas planejar, mas também acreditar." (Anatole France) 


\section{RESUMO}

CARVALHO, L. V. Efeito da sílica nanoestruturada SBA-15 na apresentação antigênica e na resposta imune. 2010. 97 f. Tese (Doutorado em Imunologia) - Instituto de Ciências Biomédicas, Universidade de São Paulo, São Paulo, 2010.

A sílica mesoporosa nanoestruturada SBA-15 devido às suas propriedades físico-química e estrutural tem demonstrado efeito adjuvante, carreando, protegendo e liberando antígenos. Nesse estudo avaliou-se o efeito da SBA-15 sobre a atividade fagocítica e morfologia de macrófagos, no recrutamento de células para órgãos linfóides, bem como na expressão de moléculas de MHC de classe II e coestimuladoras pelas APCs; seguiram-se estudos da influência do tempo de contato imunógeno:SBA-15 no potencial de adsorção e geração de anticorpos. Experimentos in vitro evidenciam que diferentes concentrações dessa partícula nanoestruturada não afetam a morfologia ou atividade de macrófagos e a integridade celular foi mantida por até 96 horas de cultura; mesmo em concentrações de até $5 \mathrm{mg} / \mathrm{mL}$, não alteram a atividade fagocítica. A SBA-15 induz o recrutamento de macrófagos, células dendríticas, CD4 ${ }^{+}$, $\mathrm{CD}^{+}$e $\mathrm{B}^{2} 20^{+}$para os linfonodos drenantes, promovendo aumento da expressão de moléculas de CD40, CD80 e CD86. As análises da cinética de produção de anticorpos demonstram que o tempo de contato imunógeno:sílica é importante na adsorção com consequente melhora da resposta imune. Esses resultados confirmam a não toxicidade da SBA-15 e sugerem que o potencial adjuvante relaciona-se com a capacidade de encapsular/adsorver antígenos e liberá-los às APCs, influenciando diretamente na reposta imune adquirida. Salienta-se que parte dos resultados apresentados nesse trabalho foram publicados na Vaccine - DOI:10.1016/j.vaccine.2010.09.087.

Palavras-chave: Adjuvante. Sílica Mesoporosa SBA-15. Células Apresentadoras de Antígenos. 


\begin{abstract}
CARVALHO, L. V. The effect of nanostructured SBA-15 in antigen presentation and immune response. 2010. $97 \mathrm{f}$. Thesis (Ph. D. in Immunology) - Instituto de Ciências Biomédicas, Universidade de São Paulo, São Paulo, 2010.
\end{abstract}

The nanostructured mesoporous SBA-15 silica due to its physical-chemical and structural properties, has shown adjuvant effect, carrying, protecting and delivering antigens. In this work was evaluate the effect of SBA-15 in the morphology and phagocytic activity of macrophages; recruitment of cells to lymphoid organs; expression of MHC class II and co-stimulatory molecules by the APCs and the influence of contact time between immunogen:SBA-15 in the potential for absorption and generation of specific antibodies. In vitro experiments showed that different concentrations of SBA-15 do not affect the morphology or macrophage activity and cells integrity were maintained up to 96 hours; moreover, higher concentrations [5 mg/mL] do not modify its phagocytic activity. SBA-15 induces the recruitment of macrophages, dendritic cells, CD4 ${ }^{+}$, $\mathrm{CD}^{+}$and $\mathrm{B}^{2} 20^{+}$to the draining lymph nodes, increasing the expression of CD40, CD80, and CD86 molecules. Analyses of antibody production showed that the contact immunogen:silica is important for adsorption and improves the immune response. These results confirms the non-toxicity of SBA-15 and suggest that the adjuvanticity of SBA-15 is related to its ability in antigens adsorption and release to APCs, directly influencing the development of the immune response. Some of the results presented in this study were published in Vaccine - DOI:10.1016/j.vaccine.2010.09.087.

Key words: Adjuvant. Mesoporous Silica SBA-15. Antigen Presenting Cells. 


\section{Lista de Abreviaturas}

$\lambda \quad$ Comprimento de onda

ACF Adjuvante completo de Freund

AIF Adjuvante incompleto de Freund

$\mathrm{Al}(\mathrm{OH})_{3}$ Hidróxido de alumínio

APC Célula apresentadora de antígeno

BSA Soro albumina bovina

CD11c $^{+}$Célula CD11c positiva

CTL Linfócito T citotóxico

CTLA4 Moléculas ligadoras de membranas do antígeno 4 associado aos linfócitos $T$ citotóxicos

DC Célula dendrítica

ELISA Ensaio imunoenzimático

Fc Cadeia pesada da imunoglobulina

FITC Isotiocianato de fluoresceína

GALT Tecidos linfóides associados à mucosa

GITR Receptor do fator de necrose tumoral induzido por glicocorticóide HGG Gama globulina humana

Hep-A Vacina contra Hepatite A

IFN- $\gamma \quad$ Interferon gama

IgG Imunoglobulina $\mathrm{G}$

IL-2 Interleucina 2

IL-4 Interleucina 4

IL-5 Interleucina 5

IL-10 Interleucina 10

IL-12 Interleucina 12

IL-13 Interleucina 13

IL-17 Interleucina 17

IL-21 Interleucina 21

IL-22 Interleucina 22

Int1 $\beta \quad$ Intimina $1 \beta$

kDa Quilodalton 
LPS Lipopolissacarídeo bacteriano

$\mathrm{M} \varphi \quad$ Macrófagos

MHC Complexo principal de histocompatibilidade

$\mathrm{MHCl}$ Complexo principal de histocompatibilidade de classe I

MHCII Complexo principal de histocompatibilidade de Classe II

MPL Mono-fosforil de lipídio A

MTP Muramil tripeptídeo

nm Nanômetro

OPD Orto-dihidrocloreto de fenilediamina

PAMP Padrão molecular expresso na superfície de patógeno

PBS Tampão salina-fosfato

PI lodeto de propídio

PE Ficoeritrina

PRR Receptor de reconhecimento de patógeno

rpm Rotação por minuto

SEM Microscopia eletrônica de varredura

$\mathrm{SiO}_{2} \quad$ Óxido de sílica

SFB Soro fetal bovino

TA Temperatura ambiente

$\mathrm{TCD}^{+}$Linfócito $\mathrm{T}$ auxiliar $\mathrm{CD} 4^{+}$

TCR Receptor de antígeno do linfócito $T$

TEM Microscopia eletrônica de transmissão

TEOS Tetraetil-ortosilicato

TGF- $\beta$ Fator de crescimento transformador $\beta$

$\mathrm{T}_{\mathrm{H}} \quad$ Linfócito $\mathrm{T}$ auxiliary

$\mathrm{T}_{\mathrm{H}} 1 \quad$ Linfócito $T$ auxiliar do tipo 1

$\mathrm{T}_{\mathrm{H}} 2 \quad$ Linfócito $\mathrm{T}$ auxiliar do tipo 2

$\mathrm{T}_{\mathrm{H}} 17 \quad$ Linfócito $\mathrm{T}$ auxiliar do tipo 17

$\mathrm{T}_{\text {reg }} \quad$ Linfócito $\mathrm{T}$ regulador

TNF- $\alpha \quad$ Fator de necrose tumoral alfa 
1 INTRODUÇÃO

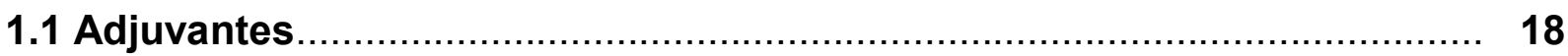

1.2 Sílicas mesoporosas altamente ordenadas........................................... 19

1.3 Células apresentadoras de antígenos e desenvolvimento da resposta imune

1.4 Camundongos geneticamente selecionados ….................................. 25

2 OBJETIVOS

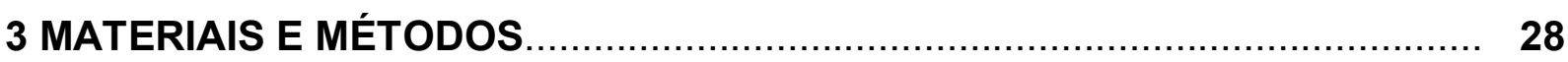

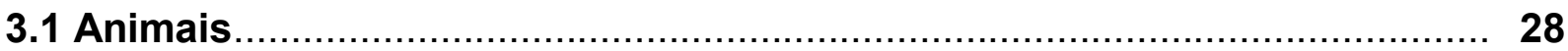

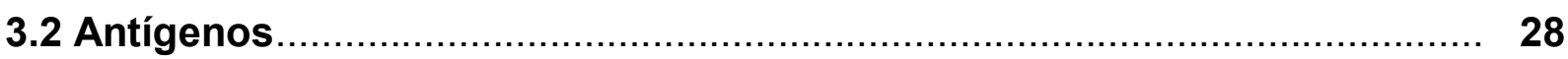

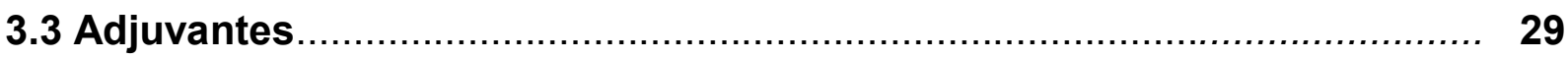

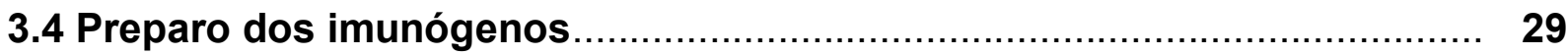

3.5 Potencial de adsorção do antígeno pela SBA-15 .................................. 29

3.6 Esquemas de Imunização............................................................. 30

3.6.1 Imunização subcutânea - base da cauda ........................................... 30

3.6.2 Imunização subcutânea - dorso................................................... 30

3.6.3 Imunização intramuscular............................................................... 31

3.6.4 Imunizações intraperitoneal............................................................ 31

3.7 Ensaio para determinação do efeito da sílica SBA-15 sobre macrófagos e células peritoneais.......................................................................... 31

3.7.1 Obtenção de macrófagos de cultura primária...................................... 31

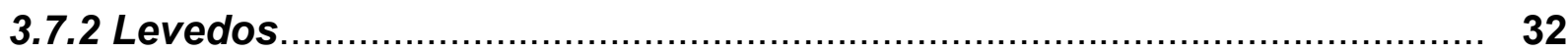

3.7.3 Efeito da SBA-15 na atividade fagocítica de macrófagos..................... 32

3.7.4 Coleta de células peritoneais.......................................................... 32

3.7.5 Incubação dos monócitos com SBA-15............................................. 33

3.7.6 Avaliação da morte celular........................................................... 33

3.8 Marcação de células para análise por citometria de fluxo........................ 34

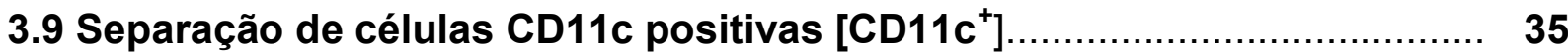

3.10 Cultivo de células linfóides estimuladas com antígenos ou mitôgeno para obtenção dos sobrenadantes........................................................... 36

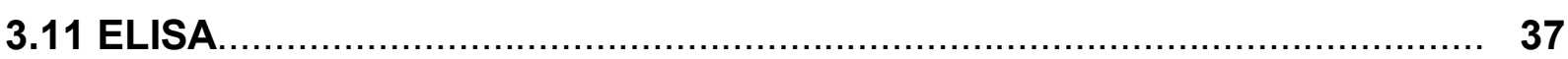


3.11.1 Determinações dos títulos de anticorpos IgG, IgG1 e lgG2a

3.11.2 Quantificação de citocinas

3.12 Ensaio in vitro de resposta proliferativa de linfócitos $T$. 38

3.13 Análise estatística

4 RESULTADOS

4.1 Efeito in vitro da sílica SBA-15 sobre macrófagos obtidos de camundongos $L_{\text {III, }} L_{\text {IVA }}$ e Swiss.

4.2 Viabilidade e necrose celular..

4.3 Imunização com vacina contra Hepatite A

4.3.1 Avaliação do tempo de contato imunógeno:SBA-15 e potencialização da adsorção

4.4 Estudo das populações celulares presentes nos linfonodos de camundongos imunizados com a vacina contra Hepatite $A$ adsorvida ou não em SBA-15

4.4.1 Expressão de moléculas de MHC-II e coestimuladoras após imunização com a vacina contra Hepatite $A$ adsorvida ou não em SBA-15.... 51

4.5 Potencial de adsorção da sílica SBA-15.

4.6 Imunização com gamaglobulina humana [HGG] 54

4.7 Influência da SBA-15 na produção de isótipos de IgG 55

4.8 Análise da produção de citocinas.

4.9 Análise da resposta proliferativa de células de camundongos imunizados com HGG; HGG:SBA-15; HGG:Al(OH)

4.10 Estudo das populações celulares presentes nos linfonodos de camundongos imunizados com HGG adsorvida em SBA-15 ou em $\mathrm{Al}(\mathrm{OH})_{3} \ldots$

4.10.1 Expressão de moléculas de MHC-II, CD40, CD80, CD86 em células de camundongos imunizados com HGG adsorvida em SBA-15 ou em AI(OH) 3 ...

4.10.2 Expressão de moléculas coestimuladoras nas APCs de camundongos imunizados com HGG adsorvida em SBA-15 ou em Al(OH) $3 . .$.

4.10.3 Expressão de moléculas MHC-Il e coestimuladoras em células

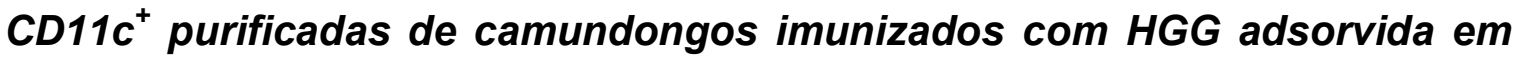
SBA-15 ou em $\mathrm{Al}(\mathrm{OH})_{3}$

5 DISCUSSÃO

6 CONCLUSÃO 
REFERÊNCIAS

79

ANEXO - ARTIGO DE PERIÓDICO 


\section{INTRODUÇÃo}

\subsection{Adjuvantes}

O avanço da biologia molecular e biotecnologia, somado ao melhor entendimento dos processos infecto-contagiosos, bem como sobre os mecanismos de imunidade protetora, permitiram o desenvolvimento de vacinas utilizando peptídeos sintéticos e proteínas recombinantes que, por serem pouco imunogênicos, requerem a adição de adjuvantes ou sistemas carreadores para a ativação efetiva das células apresentadoras de antígenos [APCs] e linfócitos T (GUPTA et al., 1993).

Adjuvantes são substâncias que amplificam e/ou modulam a imunogenicidade intrínseca de um determinado antígeno (EDELMAN; TACKET, 1990); também são capazes de modular a resposta imune em indivíduos constitutiva ou eventualmente maus respondedores, tais como idosos, imunossuprimidos, e aqueles submetidos a condições de subnutrição e de insalubridade.

Devido à diversidade química, estrutural e funcional, esses compostos agem através de diversos mecanismos incluindo: liberação lenta e/ou controlada de antígenos; proteção contra a proteólise e liberação direcionada para os tecidos linfóides associados à mucosa [GALT]; ativação e/ou modulação de células imunocompetentes tais como células dendríticas [DCs] e linfócitos, facilitando o reconhecimento e apresentação antigênica para a indução de resposta imune e geração de memória efetiva, além da indução de estímulos inflamatórios (DEGEN; JANSEN; SCHIJNS, 2003; McCLUSKIE; WEERATNA, 2001; EDELMAN, 2002).

Dentre as substâncias com potenciais adjuvantes já descritas encontram-se as emulsões de água em óleo, surfactantes naturais e sintéticos, géis minerais e produtos bacterianos (BREWER, 2006). No entanto, os sais de hidróxido e fosfato de alumínio; a emulsão óleo em água [MF-59], bem como a combinação do mono-fosforil de lipídio A com alumínio [AS04] são os mais utilizados em humanos (ULMER; VALLEY; RAPPUOLI, 2006; PODDA; DEL GIUDICE, 2003; VERNACCHIO et al., 2002). Outros como, Adjuvante Incompleto de Freund [AIF], Mycobacterium vaccae, fatores de 
crescimento/citocinas, seqüências de $\mathrm{CpG}$, muramil tripeptídeo [MTP] e lipossomos (SMITH, et al., 2003; ARKWRIGHT; DAVID, 2001; CEBON, 2003; DRANOFF, 2002; WEINER, 2000; ALVING, 2002; DE ALMEIDA, et. al., 2006; QUINTILIO et al., 2009) estão em fase préclínica de desenvolvimento, enquanto a saponina QS-21 (WAITE et al., 2001) encontra-se em etapa de ensaios clínicos.

Os derivados de alumínio compõem a maioria das vacinas bacterianas e virais licenciadas para uso em humanos; no entanto, esses adjuvantes induzem resposta imunológica qualitativamente direcionada quanto à classe de linfócitos $\mathrm{T}$ auxiliares $\left[\mathrm{T}_{\mathrm{H}} 2\right]$, caracterizada pela produção de citocinas $\mathrm{IL}-4$ e $\mathrm{IL}-5$, ativação e expansão de células B antígeno-específicas e produção de lgE por indução e ativação da população de eosinófilos $\mathrm{Gr} 1^{+}$[produtores de IL-4] (LINDBLAD, 2004; JORDAN, 2004; WANG; WELLER, 2008). Após emprego desses adjuvantes, têm sido relatadas reações locais adversas como eritema, nódulos subcutâneos, hipersensibilidade de contato, além de inflamação granulomatosa (ERODOHAZI; NEWMAN, 1971; COLLIER; POLAKOFF; MORTIMER, 1979; CLEMMENSEN; KNUDSEN, 1980; FROST et al., 1985; STRAW et al., 1985).

Diante desses relatos e pela importância das vacinações para a saúde pública, tornam-se relevantes os estudos sobre estratégias racionais para o desenvolvimento de novos adjuvantes, passíveis de emprego em humanos, que sejam seguros e eficientes na melhora da imunogenicidade, na indução de resposta duradoura e de memória imunológica efetiva.

\subsection{Sílicas mesoporosas altamente ordenadas}

As sílicas mesoporosas são partículas de óxido de silício $\left[\mathrm{SiO}_{2}\right] \mathrm{com}$ estrutura porosa altamente organizada que, devido às suas propriedades físico -químicas e seus potenciais de aplicação em diferentes áreas, têm despertado grande interesse à comunidade científica e em segmentos tecnológicos. Esses materiais são capazes de interagir com átomos, íons e moléculas, não apenas em sua superfície, como também interiormente, possuindo grande aplicabilidade em processos de troca de íons, adsorção, catálises entre outros 
(KRESGE et al., 1992; YANG; COOMBS; OZIN, 1997). Dentre as sílicas mesoporosas, a SBA-15, descrita em 1998, adquiriu importância nas áreas de nanotecnologia e nanobiotecnologia. Esse material é sintetizado em meio ácido por auto-agregação de espécies de silicato utilizando o copolímero tribloco, o poli-[óxido de etileno]-poli[óxido de propileno]-poli[óxido de etileno] $\left[\mathrm{EO}_{20} \mathrm{PO}_{70} \mathrm{EO}_{20}\right]$ como agente direcionador de estrutura (ZHAO et al., 1998a, 1998b). A SBA-15 apresenta estrutura hexagonal com poros altamente ordenados e interligados [aproximadamente $10 \mathrm{~nm}$ ], paredes relativamente espessas e notável estabilidade térmica, hidrotérmica e mecânica (Figura 1) (ZHAO et al., 1998a, 1998b; MATOS et al., 2001).

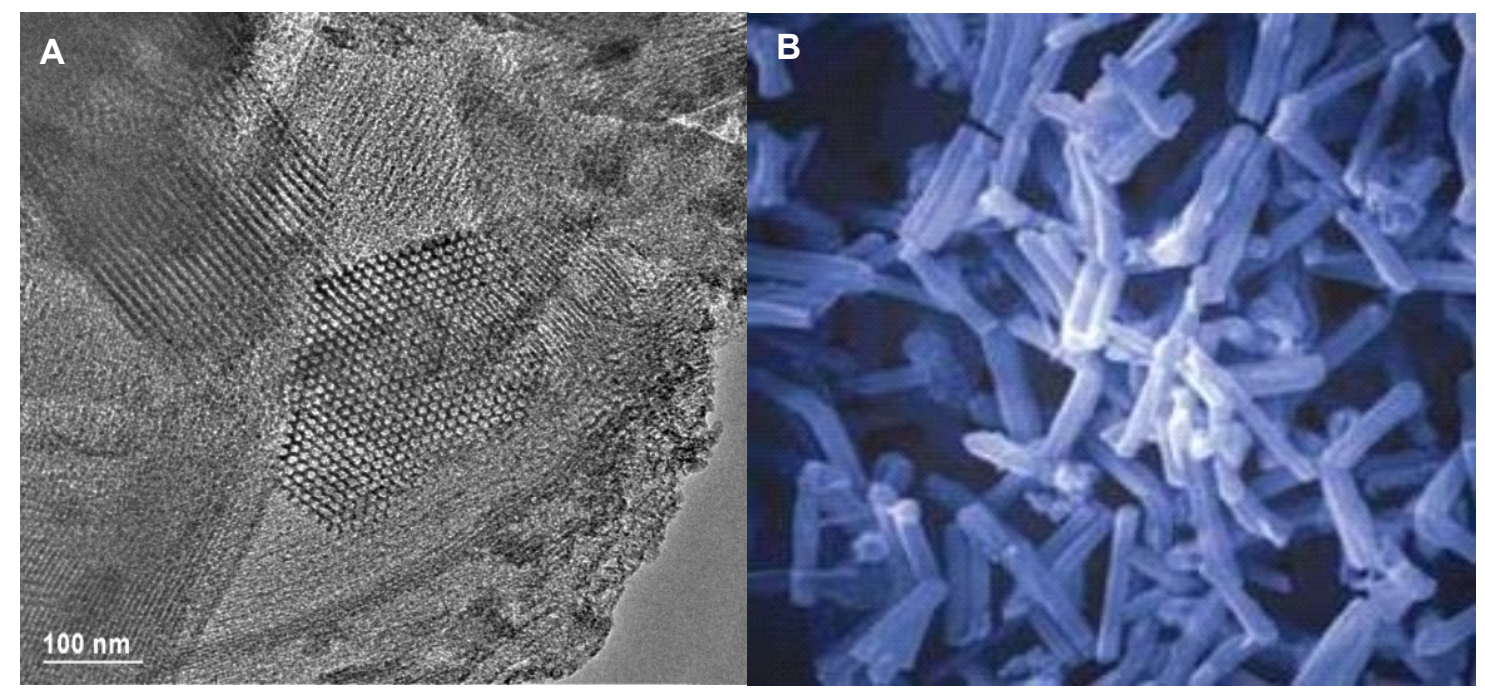

Figura 1 - Microscopia eletrônica de transmissão da sílica mesoporosa nanoestruturada SBA-15. [A] Estrutura de poros arranjados hexagonalmente dentro dos tubos cilíndricos de comprimento $\sim 2 \mu \mathrm{m}$. [B] Interior de uma partícula mostrando a macroporosidade e os tubos cilíndricos de sílica. Tamanho médio da partícula: $30 \mu \mathrm{m}$. Diâmetro dos poros: $\sim 10 \mathrm{~nm}$. Medidas: Laboratório Nacional de Luz Síncrotron [LNLS] e POLI [USP].

Apesar dos vários estudos utilizando essa sílica como veículo para diferentes substâncias, ainda não haviam avaliado a sua capacidade em encapsular, carrear, proteger e apresentar antígenos ao sistema imunológico.

Trabalhos desenvolvidos há mais de duas décadas demonstraram que a administração de sílicas coloidais afeta a atividade das enzimas lisossomais de macrófagos, alterando muitas das suas funções catabólicas, como o efeito 
bactericida. A hipótese vigente era de que, consequentemente, qualquer efeito de bloqueio de funções dos macrófagos propiciaria ou facilitaria a atuação de outras células mais eficazes quanto à apresentação de antígenos e desenvolvimento da resposta imune, melhorando consistentemente a produção de anticorpos (ALLISON; HARINGTON; BIRBECK, 1966; BECKER; RUDBACH, 1979; GERY; LEPE-ZUNIGA, 1984; KAMPSCHMIDT; WORTHINGTON; MESECHER, 1986; LOTZOVA; CUDKOWICZ, 1974; VOGEL; ENGLISH; O'BRIEN, 1982).

Baseados nos resultados descritos acima e nas propriedades da sílica SBA-15, iniciaram-se, no Laboratório de Imunoquímica do Instituto Butantan, estudos sobre a viabilidade de emprego desse material como adjuvante e sobre seu potencial de carrear e liberar diferentes antígenos às células imunocompetentes, potencializando a resposta imunológica. Dessa forma, nosso grupo descreveu a característica adjuvante da sílica SBA-15 na indução de resposta de anticorpos. No primeiro estudo, a encapsulação/adsorção de antígenos de natureza distinta como a Intimina $1 \beta$ de $E$. coli, proteínas do veneno de Micrurus e soro albumina bovina [BSA] à SBA-15 induziu imunidade duradoura e efetiva em camundongos geneticamente selecionados $\mathrm{e}$ isogênicos, sendo que não se observou formação aparente de granulomas, nem outros efeitos indesejáveis (MERCURI et al., 2006). Ainda, verificou-se que essa sílica foi capaz de modular positivamente a produção de anticorpos de camundongos geneticamente selecionados para a baixa resposta [Linhagem L] de duas seleções genéticas independentes - Seleções III e IVA, diminuindo significantemente as diferenças entre os níveis de anticorpos interlinhagens $\mathrm{H}-\mathrm{L}$ em ambas as Seleções (CARVALHO, 2007; CARVALHO et al., 2010, prelo). Mais ainda, SCARAMUZZI, 2009 verificou que a imunização pela via oral com gamaglobulina humana $[H G G]$ e vacina contra Hepatite $A$ [Hep-A] em SBA-15 induziu aumento significativo nos títulos de anticorpos séricos das classes $\lg \mathrm{G}$ e $\lg \mathrm{A}$ e $\lg \mathrm{A}$ secretada.

Esses dados, em conjunto, demonstram a participação da SBA-15 na ativação efetiva do sistema imunológico e na geração de memória, mecanismo essencial para a proteção induzida por processos de vacinação.

Em 12 de setembro de 2005 foi depositada a Patente COMPLEXO IMUNOGÊNICO FORMADO POR ANTÍGENOS VACINAIS ENCAPSULADOS 
POR SÍLICA MESOPOROSA NANOESTRUTURADA, em parceria com o Laboratório Cristália, que recebeu o número PI 0503817-0 e, em 2009 seu depósito internacional [WO 07030901].

\subsection{Células apresentadoras de antígenos e desenvolvimento da resposta imune}

A ativação, supressão e regulação que se desenvolvem no decurso da resposta imune, que envolvem o discernimento do próprio e não próprio e de memória, dependem de sinais transmitidos por receptores presentes nas membranas das células, ou por moléculas secretadas pelos vários tipos celulares que compõem o sistema imunológico. Os linfócitos $B$, precursores dos plasmócitos secretores de anticorpos, podem reconhecer antígenos na sua conformação nativa por ligação direta às imunoglobulinas expressas nas suas superfícies. Porém, os receptores de antígenos dos linfócitos T [TCR] reconhecem os antígenos processados e ligados às moléculas do Complexo Principal de Histocompatibilidade [MHC] expressas na superfície das APCs (GERMAIN; MARGULIES, 1993).

Há duas classes de proteínas ligantes de peptídeos, as MHC classe I e II, capazes de apresentarem peptídeos aos linfócitos T citotóxicos $C D 8^{+}[C T L]$ e aos linfócitos $\mathrm{T}$ auxiliares $\mathrm{CD} 4^{+}\left[\mathrm{T}_{\mathrm{H}}\right]$, respectivamente. Antígenos intracelulares são degradados por proteassomas no citosol e os peptídeos derivados ligamse às moléculas de classe I para serem reconhecidos pelos CTL, os quais, uma vez ativados, podem eliminar diretamente as células-alvo. Antígenos extracelulares, por sua vez, são internalizados pelas APCs e transportados para compartimentos ácidos vesiculares [endossoma/lisossoma] onde são degradados por proteinases gerando fragmentos peptídicos que são ligados às moléculas de MHC-II e apresentados aos linfócitos $T_{H}$, que regulam a resposta imune (GERMAIN; MARGULIES, 1993; YORK; ROCK, 1996; WOLF; PLOEG, 1995). Entretanto, a via clássica de apresentação antigênica restrita ao MHC não é exclusiva. Alguns antígenos endógenos podem ser apresentados pela via endógena restrita ao MHC-II enquanto, alguns antígenos exógenos, são capazes de induzir resposta citotóxica restrita aos de classe I (MATOUSEK; NEDRUD; HARDING, 1996; JONDAL; SCHIRMBECK; REIMANN, 1996). 
As APCs - macrófagos [M 4 ], DCs e linfócitos B - através do complexo MHC/peptídeos, moléculas coestimuladoras e produção de citocinas, são essenciais para a ativação e regulação da resposta mediada por linfócitos $\mathrm{T}$. Essas células se diferenciam pela forma de captação e natureza do antígeno por elas apresentado, pela expressão de moléculas coestimuladoras e de classe II e na distribuição nos tecidos linfóides secundários. M $\varphi$ são células fagocíticas localizadas em vários tecidos do organismo que reconhecem os micro-organismos e antígenos particulados através de receptores específicos para padrões moleculares expressos na superfície dos patógenos [PAMPs] e, após estímulo via receptor passam a expressar moléculas coestimuladoras e MHC de classe II, podendo agir como APCs. As células B, presentes nos folículos linfóides, capturam e internalizam antígenos solúveis após ligação direta às imunoglobulinas de superfície, sendo induzidas a expressar moléculas coestimuladoras, passando a ter função de APCs (JANEWAY et al., 2001).

As DCs são células altamente eficientes na apresentação dos antígenos aos linfócitos T e encontram-se nas formas DCs imaturas ou maduras. As primeiras se localizam na maioria dos tecidos não linfóides e possuem altos níveis de receptor de reconhecimento de patógenos [PRRs] sendo altamente eficazes na captura e processamento dos antígenos; durante infecção e/ou inflamação, migram para os órgãos linfóides, onde se tornam maduras aumentando a expressão de MHC classe I e II, moléculas coestimuladoras e de adesão, possuindo grande potencialidade de ativar os linfócitos T antígenoespecíficos. Desta forma, as DCs são consideradas sentinelas móveis do sistema imunológico com capacidade de iniciar e manter a resposta imune adquirida (BANCHEREAU; STEINMAN, 1998).

Sendo a captura do antígeno pelas APCs uma etapa importante na indução da resposta, as pesquisas e o desenvolvimento de sistemas carreadores que protejam e liberem o antígeno diretamente para as APCs, em especial DCs, têm recebido atenção especial (ARDAVIN, 2003; BANCHEREAU; STEINMAN, 1998). Para que peptídeos sintéticos, proteínas nativas solúveis e/ou recombinantes possam induzir a maturação das APCs levando a uma estimulação efetiva do sistema imune, é necessária a administração combinada com adjuvantes que potencializem o processamento 
e apresentação dos antígenos aos linfócitos $T$, ativando-os eficientemente (AICHELE et al., 1995).

Após ativação, as células $\mathrm{CD}^{+}$podem se diferenciar em várias subpopulações efetoras, incluindo as $T_{H} 1$ e $T_{H} 2$, as $T_{H} 17$ e as células $T$ reguladoras $\left[\mathrm{T}_{\mathrm{Reg}}\right]$. No entanto, a polarização dos linfócitos $\mathrm{T}_{H}$ é complexa e, como todo segmento da resposta imune, inclui fatores genéticos e ambientais como dose do antígeno, natureza do agente infeccioso, duração do estímulo antigênico, e das citocinas expressas no local onde as APCs encontram-se expostas (MOSMANN; COFFMAN, 1989a; MOSMANN; SAD, 1996b; O'GARRA, 1998). As subpopulações de linfócitos $T_{H}$ podem regular uma a outra, uma vez uma dominante, dificilmente reverte-se a resposta.

A resposta $T_{H} 1$, efetiva nas respostas contra micro-organismos intracelulares, é acompanhada pela secreção de interleucina-2 [IL-2] e interferon- $\gamma$ [IFN- $\gamma]$, favorecendo respostas imunes mediadas por células, ativação de células $\mathrm{CD}^{+}$citotóxicas e a produção de anticorpos fixadores de complemento [IgG2a, IgG3] (MOSMANN; COFFMAN, 1989a; TRINCHIERI, 1995). A resposta $T_{H} 2$ é caracterizada pela produção de IL-4, IL-5 e IL-13 ativando células $B$ e induzindo preferencialmente produção de anticorpos lgG1, $\lg E$ e $\lg A$ em camundongos e $\lg E$ e $\lg G 4$ em humanos, os quais atuam principalmente no controle contra helmintos e outros patógenos extracelulares (MOSMANN; COFFMAN, 1989a; KELLEHER; MAROOF; KNIGHT, 1999). As células $T_{H} 17$ produzem IL-17, IL-17F, IL-21 e IL-22 e estão relacionadas com a inflamação inicial, defesa contra bactérias e parasitas extracelulares e autoimunidade (MOSMANN; SAD, 1996; HARRINGTON; MANGAN; WEAVER, 2006). Já, as células $T$ reguladoras $\left[T_{R e g}\right]$, uma população de células $C D 4^{+}$que expressam naturalmente altos níveis de CD25 e fator de transcrição [Foxp3], controlam o balanço entre tolerância e resposta imune através da ação de fator de crescimento transformador $\beta$ [TGF- $\beta$ ] e/ou IL-10, de moléculas ligadoras de membranas do antígeno 4 associado aos linfócitos T citotóxicos [CTLA4] e do receptor do fator de necrose tumoral induzido por glicocorticóide [GITR] (BELKAID; ROUSE, 2005).

Muitos dos adjuvantes existentes e comumente utilizados nos protocolos de vacinação exercem forte influência no tipo da resposta imune a determinado antígeno quanto à classe de $T_{H}$ bem como na predominância de expressão de 
determinado isótipo de IgG (HADJIPETRTOU-KOUROUNAKIS; MÖLLER, 1984). O estudo de novos adjuvantes que não interfiram na polarização da resposta imunológica é de grande valia para o desenvolvimento de vacinas contra patógenos intracelulares, especialmente vírus.

\subsection{Camundongos Geneticamente Selecionados}

Linhagens de camundongos geneticamente selecionados para a produção máxima [High - H] ou mínima [Low - L] de anticorpos a diferentes imunógenos naturais foram obtidas por cruzamentos seletivos bidirecionais, evitando-se a consangüinidade, a partir de populações geneticamente heterogêneas. Oito seleções foram realizadas e, em cada uma dessas, as linhagens $H$ e $L$ divergiram progressivamente de geração a geração, e as separações máximas interlinhagens [limites de seleção] foram alcançadas entre as gerações $F_{7}$ e $F_{16}$ dos diferentes processos seletivos. Atingindo o limite de seleção, a continuidade dos cruzamentos seletivos não altera as diferenças interlinhagens, indicando homozigose dos alelos $h$ nas linhagens $\mathrm{H}$ e dos alelos I nas L (BIOZZI et al., 1979).

Durante os processos seletivos, diferentes grupos de genes foram afetados, possivelmente em função da complexidade do imunógeno selecionador e do esquema de imunização utilizado durante a seleção (BIOZZI et al., 1979; CABRERA et al., 1982; BIOZZI et al., 1982; SANT'ANNA et al., 1982). Consequentemente, os fenótipos de respostas máxima ou mínima de anticorpos resultaram de modificações em diferentes etapas dos processos imunorreguladores, interferindo na potencialidade de diferentes células imunocompetentes. Desta forma, as diferenças fenotípicas existentes entre os camundongos H e L das Seleções Genéticas I, II e IV-A, obtidos segundo a resposta primária a eritrócitos heterólogos devem-se, principalmente, à alta atividade catabólica dos macrófagos nos camundongos $L_{\|}$, $L_{\|}$e $L_{\text {IVA }}$ (CABRERA et al., 1982; BIOZZI et al., 1984). Entretanto, nos camundongos $\mathrm{H}$ e L das Seleções III e IV, obtidos segundo a resposta secundária contra antígenos flagelares e somáticos de Salmonellae, as diferenças nas respostas de anticorpos devem-se, essencialmente, às modificações genéticas intrínsecas na potencialidade dos linfócitos (FERREIRA; GENNARI; REIS, 1985). 
Gennari, et al. (1987) demonstraram que a administração de partículas de sílica coloidal, durante quatro dias consecutivos previamente à imunização de camundongos LIVA com eritrócitos de carneiro, antígeno altamente imunogênico, modulou a resposta humoral, promovendo aumento dos títulos de anticorpos nesses camundongos, diminuindo significativamente as diferenças interlinhagens $\mathrm{H}_{\text {IVA }}$ - LIVA durante todo o período pós-imunização analisado [cerca de 40 dias]. No entanto, o tratamento com sílica não interferiu na cinética de produção de anticorpos de animais de linhagens de outra seleção genética, os $H_{\| I}$ e $L_{\text {III }}$ (SIQUEIRA et al., 1977; SANT'ANNA et al., 1982), que diferem na produção de anticorpos devido à potencialidade dos linfócitos.

Esses resultados estão correlacionados com os trabalhos citados no item 1.2 da Introdução (ALLISON; HARINGTON; BIRBECK, 1996; BECKER; RUDBACH, 1979; GERY; LEPE-ZUNIGA, 1984; KAMPSCHMIDT; WORTHINGTON; MESECHER, 1986; LOTZOVA; CUDKOWICZ, 1974; VOGEL; ENGLISH; O'BRIEN, 1982), nos quais se verificou que a fagocitose de partículas de sílica coloidal altera funções catabólicas dos macrófagos, permitindo que células mais eficazes atuem na apresentação e ativação do sistema imune, potencializando a resposta de anticorpo desenvolvida nos LIVA.

Estudos realizados por ocasião do Mestrado demonstraram que a sílica SBA-15 também foi capaz de modular positivamente a resposta imune humoral dos camundongos $L$ das Seleções III e IVA, eliminando as diferenças interlinhagens H - L (CARVALHO, 2007; CARVALHO et al., 2010, prelo). Diante desse resultado, experimentos in vitro utilizando-se cultura de células serão de grande valia para analisarmos os efeitos dessa nanopartícula nas APCs. 


\section{OBJETIVOS}

O objetivo desse estudo foi avaliar a capacidade da sílica SBA-15 em potencializar a apresentação antigênica através da:

$>$ Análise do efeito da SBA-15 na atividade fagocítica e morfologia de macrófagos derivados de precursores da medula óssea de camundongos geneticamente selecionados para baixa resposta de anticorpos [ IIII; $_{\text {IVA }}$ e geneticamente heterogêneos [Swiss];

$>$ Estudo da resposta à vacina da Hepatite A e/ou HGG adsorvida em SBA-15:

- Imunizações em camundongos geneticamente selecionados para baixa resposta de anticorpos [ $\mathrm{L}_{\text {III] }}$ pela via subcutânea; intramuscular; intraperitoneal;

- Análise da cinética de produção de anticorpos da resposta primária e secundária antígeno-específicos;

- Análise da influência do tempo de contato imunógeno:SBA-15 na otimização da adsorção e geração da resposta imunológica.

> Estudo do padrão de secreção de citocinas por células de camundongos imunizados com antígenos adsorvidos a SBA-15;

> Análise efeito da SBA-15 na resposta proliferativa de linfócitos T;

> Análise das populações celulares nos linfonodos drenantes, bem como da expressão de moléculas envolvidas na apresentação antigênica;

Análise do efeito da SBA-15 na ativação de células CD11c ${ }^{+}$; 


\section{MATERIAL E MÉTODOS}

\subsection{Animais}

Para análise do efeito da sílica SBA-15 nas APCs e na resposta à vacina contra Hepatite A e HGG, foram utilizados camundongos isogênicos BALB/c e heterogêneos Swiss, fêmeas com 6 a 8 semanas de idade, criados e fornecidos pelo Biotério Central do Instituto Butantan. Utilizamos ainda camundongos das linhagens más respondedoras das Seleções III e IVA [L III, LIVA], machos e/ou fêmeas de 6 a 8 semanas de idade, provenientes do Biotério do Laboratório de Imunogenética do Instituto Butantan.

No decurso das imunizações, os animais foram sangrados através do plexo venoso retro-orbital e os antissoros foram estocados a $-20{ }^{\circ} \mathrm{C}$ para posterior avaliação da cinética de produção de anticorpos $\lg G$ e isótipos $\lg G_{1}$ e $\lg _{2 a}$ anti- Hepatite A e/ou anti-HGG, pela técnica de ELISA, descrita na seção 3.6.

Todos os procedimentos realizados foram aprovados pelas Comissões de Ética em Experimentação Animal do Instituto Butantan [ $n^{\circ} 356 / 06$ ] e do Instituto de Ciências Biomédicas da USP [nº 012 nas fls. 42 do livro 2].

\subsection{Antígenos}

Salienta-se que o efeito adjuvante da SBA-15 é um fenômeno biológico e como tal, imunógenos de natureza e estruturas distintas foram adsorvidos à sílica SBA-15. Dentre esses, utilizou-se nesse estudo a vacina contra Hepatite A [HEP-A] [Merck \& Co., Inc., Whitehouse Station, NJ, EUA] e a proteína gamaglobulina humana [HGG] de 150 kDa [Sigma-Aldrich Biotechnology Co., St. Louis, MO, EUA]. 


\subsection{Adjuvantes}

A sílica SBA-15 foi sintetizada pelo Dr. Jivaldo R. Matos do Instituto de Química da Universidade de São Paulo - USP, e as análises físico-químicas realizadas pela Dra. Márcia C. A. Fantini do Instituto de Física - USP.

O gel de hidróxido de alumínio $\left[\mathrm{Al}(\mathrm{OH})_{3}\right]\left[30 \mathrm{~g}\right.$ de $\mathrm{AlNH}_{4}\left(\mathrm{SO}_{4}\right) 2.12 \mathrm{H}_{2} \mathrm{O} /$ $360 \mathrm{~mL} \mathrm{H} \mathrm{H}_{2} \mathrm{Od} / 150 \mathrm{~mL}$ de $\mathrm{NaOH} 1 \mathrm{~N}$ ] foi utilizado para comparação às imunizações realizadas com SBA-15.

\subsection{Preparo dos imunógenos}

Para atingir a concentração desejada, a vacina contra Hepatite A e a HGG foram diluídas em solução salina-fosfato [PBS] $\mathrm{pH} \quad 7,4$ e adicionadas/misturadas [v/v] ou não a SBA-15 e ao $\mathrm{Al}(\mathrm{OH})_{3}$.

Devido aos dados físico-químicos, previamente determinados pela Dra. Márcia C. A. Fantini, em ensaios de incorporação de antígenos na estrutura mesoporosa da SBA-15 com amostras submetidas à evaporação ou à filtração, seguiram-se os estudos da influência do tempo de contato imunógeno:SBA-15 no potencial adjuvante dessa nanopartícula. Assim, a vacina contra Hepatite $A$ foi previamente adsorvida a SBA-15, 3, 8, 30 ou 180 dias antes da imunização comparativamente ao imunógeno preparado no momento da imunização [HEP-A:SBA-15 0h].

\subsection{Potencial de adsorção do antígeno pela SBA-15}

O potencial de adsorção da sílica SBA-15 foi determinado in vitro utilizando-se diferentes proporções [1:5; 1:10; 1:25] de HGG:SBA-15 [v/v] diluída em PBS em volume final de $1 \mathrm{~mL}$. As proteínas não adsorvidas foram removidas por centrifugação a $400 \times \mathrm{g}$ por 3 minutos a $25^{\circ} \mathrm{C}$ e determinou-se a concentração em $\mathrm{mg} / \mathrm{mL}$ de HGG presente no sobrenadante através da leitura em espectrofotômetro em $\lambda 280 \mathrm{~nm}$. Como controle, utilizou-se solução de 
SBA-15; HGG em PBS nas mesmas concentrações citadas acima, em volume final de $1 \mathrm{~mL}$.

\subsection{Esquemas de imunização}

Para avaliação do efeito da SBA-15 na apresentação antigênica e resposta a vacina para Hepatite A ou a HGG, camundongos BALB/c e $L_{\text {III }}$ foram imunizados com vacina contra Hepatite A ou HGG por diferentes protocolos de imunização, conforme descrito nos itens a seguir.

\subsubsection{Imunização subcutânea - base da cauda}

Para análise do efeito da SBA-15 no recrutamento celular, expressão de moléculas MHC-II e coestimuladoras, ensaio de proliferação celular, produção de citocinas in vitro e ativação de DCs, camundongos BALB/c [n=4-5/grupo] foram imunizados ou não pela via subcutânea [base da cauda] com $200 \mu \mathrm{L}$ [100 $\mu \mathrm{L}$ de cada lado] com 0,48 $\mu \mathrm{g} /$ animal da vacina contra HEP-A em PBS; vacina adsorvida em $12 \mu \mathrm{g} / \mathrm{animal}$ de SBA-15; $10 \mu \mathrm{g} / \mathrm{animal}$ de HGG em PBS; $10 \mu \mathrm{g} / \mathrm{animal}$ de HGG em $250 \mu \mathrm{g} / \mathrm{animal}$ de SBA-15; $10 \mu \mathrm{g} / \mathrm{animal}$ de HGG em $250 \mu \mathrm{g} /$ animal de $\mathrm{Al}(\mathrm{OH})_{3}$ ou inoculados com 12 e/ou $250 \mu \mathrm{g} / \mathrm{animal}$ de SBA15.

\subsubsection{Imunização subcutânea - dorso}

Avaliações do tempo de contato imunógeno:SBA-15 e potencialização da adsorção foram realizadas em camundongos $L_{\text {III }}$ [n=5/grupo] imunizados pela via subcutânea, em volume final de $200 \mu \mathrm{L}$, com 0,48 $\mu \mathrm{g} / \mathrm{animal}$ da vacina contra Hepatite A adsorvida ou não a 12 mg/animal de SBA-15 durante 3, 8, 30 ou 180 dias antes da imunização, ou ainda, adsorvida no momento da imunização [HEP-A:SBA-15 0h]. Para a determinação da resposta secundária, animais receberam 0,48 $\mu$ g/animal da vacina contra Hepatite A 150 dias após a primeira imunização. 


\subsubsection{Imunização intramuscular}

Para o estudo comparativo do potencial efeito adjuvante da sílica SBA-15, camundongos geneticamente selecionados para a má resposta de anticorpos [ $\left.\mathrm{L}_{\mathrm{III}}\right]$ [ $\mathrm{n}=3$ animais/grupo] foram imunizados pela via intramuscular com 0,48 $\mu \mathrm{g} /$ animal da vacina adsorvida a $12 \mu \mathrm{g} / \mathrm{animal}$ de SBA-15; vacina adsorvida a $12 \mu \mathrm{g} /$ animal de $\mathrm{Al}(\mathrm{OH})_{3}$ ou ainda sem qualquer adjuvante. Para análise dos títulos de anticorpos secundários, 160 dias após a primeira imunização administrou-se segunda dose da vacina adsorvida a SBA-15 em todos os grupos experimentais.

\subsubsection{Imunização intraperitoneal}

Camundongos $L_{I I I}$ [ $n=3$ animais/grupo] foram imunizados pela via intraperitoneal com $10 \mu \mathrm{g} / \mathrm{mL}$ de HGG adsorvido em $250 \mu \mathrm{g} / \mathrm{mL}$ de SBA-15 ou em $250 \mu \mathrm{g} / \mathrm{mL}$ de $\mathrm{Al}(\mathrm{OH})_{3}$. Os animais receberam segunda dose de HGG adsorvida a SBA-15 no $60^{\circ}$ dia após a primeira imunização.

\subsection{Ensaio para a determinação do efeito da sílica SBA-15 sobre macrófagos e células peritoneais}

\subsubsection{Obtenção de macrófagos de cultura primária}

$M \varphi$ foram gerados a partir de precursores da medula óssea de camundongos geneticamente heterogêneos Swiss e das linhagens LIVA $_{\text {e }}$ LIII, $_{\text {, }}$ cultivados em placas de Petri bacteriológicas de $10 \mathrm{~cm}$ de diâmetro por 7 dias em meio RPMI - 1640 contendo 15 mM de HEPES, $2 \mathrm{~g} / \mathrm{L}$ bicarbonato de sódio, $1 \mathrm{mM}$ de L-glutamina suplementado com $20 \%$ de SFB e $30 \%$ de meio condicionado por células L929 [LCCM]. Os macrófagos diferenciados foram removidos através de pipetagem rigorosa após incubação a $4{ }^{\circ} \mathrm{C}$ durante 20 minutos em presença de meio Hanks. Após a contagem, as células foram distribuídas na concentração de $2 \times 10^{5}$ macrófagos/poço em placas de cultura de 24 poços sobre lamínulas de vidro [13 $\mathrm{mm}$ de diâmetro] em meio RPMI 
suplementado com 10\% de SFB e 5\% de LCCM. As culturas foram mantidas a em estufa a $37{ }^{\circ} \mathrm{C}$ em $5 \%$ de $\mathrm{CO}_{2}$ atmosférico.

\subsubsection{Levedos}

Saccharomyces cerevisiae desidratados obtidos de fermento de padaria foram suspendidos em PBS, autoclavados e lavados $4 x$ através de centrifugação em PBS estéril. A desagregação dos levedos mortos por calor foi realizada por passagem em agulha de $26 \mathrm{G} \times 1 / 2$ polegadas.

\subsubsection{Efeito da SBA-15 na atividade fagocítica de macrófagos}

Para análise do efeito da sílica sobre a atividade fagocítica dos macrófagos, diferentes concentrações de SBA-15 [20; 50; 100; 200; 500 e $1000 \mu \mathrm{g} / \mathrm{mL}$ ] foram adicionadas às culturas de macrófagos por 1 hora a $37^{\circ} \mathrm{C}$. Após incubação, adicionou-se Saccharomyces cerevisae na proporção de 3 levedos/célula durante 1 hora em meio RPMI contendo $10 \%$ SFB a $37^{\circ} \mathrm{C}$ e $5 \%$ de $\mathrm{CO}_{2}$. Após este período, para remoção dos levedos livres, as culturas foram lavadas com meio Hanks e incubadas durante diferentes tempos $[1 ; 24 ; 48 ; 72$ e 96horas]. As células foram lavadas e fixadas durante 1 hora com metanol [Merck KGaA, Darmstadt, Germany] e coradas com May- Grünwald e Giemsa [Merck KGaA, Darmstadt, Germany]. O grupo controle foi mantido apenas com levedo. Células foram contadas em microscópio de contraste de fase em aumento de 1.000 x. No mínimo, 200 células foram contadas por lamínula. A capacidade fagocítica foi determinada a partir da porcentagem de células infectadas, bem como do número de levedos internalizados por cada macrófago. Cada experimento foi realizado em triplicata e os valores representam a média da triplicata de 2 experimentos independentes.

\subsubsection{Coleta de células peritoneais}

Para análise do efeito da SBA-15 na viabilidade e alteração morfológica, macrófagos foram obtidos a partir de lavado peritoneal de camundongos 
BALB/c não imunizados, na ausência de estímulo inflamatório, após sacrifício dos mesmos e exposição do peritôneo. Injetou-se na cavidade peritoneal dos camundongos aproximadamente $5 \mathrm{~mL}$ de meio de cultura RPMI - 1640 [Cultilab Ltda., São Paulo, SP, Brasil] contendo 15 mM de HEPES, 2 g/L bicarbonato de sódio, $1 \mathrm{mM}$ de glutamina na ausência de soro fetal bovino. Após massagem do peritôneo, o fluido proveniente do lavado peritoneal foi coletado, centrifugado e as células coletadas foram lavadas com tampão PBS [pH 7,4] estéril. As células foram contadas utilizando-se a câmara de Neubauer e a viabilidade foi determinada com o auxílio do corante Azul de Trypan. Após a contagem, as células foram ressuspendidas em meio RPMI na ausência de SFB, e mantidas em gelo até serem utilizadas. $3 \times 10^{5}$ células foram colocadas em cada poço da "chamber slide" contendo 8 poços [Nalge Nunc International Corp, Naperville, IL, USA] e incubadas em estufa a $37^{\circ} \mathrm{C}$ contendo $5 \%$ de $\mathrm{CO}_{2}$ e $96 \%$ de umidade por 1 hora para propiciar a aderência dos monócitos. As células não aderentes foram removidas por lavagem com meio RPMI.

\subsubsection{Incubação dos monócitos com SBA-15}

As células aderidas à placa de vidro foram incubadas por 4 ou 24 horas a $37^{\circ} \mathrm{C}, 5 \%$ de $\mathrm{CO}_{2}, 96 \%$ de umidade, com diferentes concentrações de SBA15 [50,100,200, $1500 \mu \mathrm{g} / \mathrm{mL}$ de SBA-15; $20 \%$ de soro em meio; $0,3 \mathrm{~mL} /$ poço da "chamber slide"]. Após incubação, os sobrenadantes dos poços da câmara foram descartados e os poços lavados duas vezes com tampão PBS estéril. As células de cada tratamento foram analisadas quanto a sua viabilidade por citometria de fluxo a partir da ligação de iodeto de propídio [PI].

\subsubsection{Avaliação da morte celular}

Para análise da viabilidade e necrose por citometria de fluxo, as células tratadas com diferentes concentrações de SBA-15 foram incubadas com PI conforme recomendado pelo fabricante [R\&D Systems Inc., Minneapolis, MN, USA]. Seguiu-se análise em citômetro de fluxo [FacScalibur - Becton \& 
Dickson, San Jose, CA, EUA]. As análises de detecção de morte das células peritoneais após tratamento com SBA-15, foram repetidas duas vezes. Para confirmar a inviabilidade celular, monócitos aderidos as placas de vidro foram corados por Hematoxilina-Eosina [HE] [Merck, Darmstadt, Germany] e analisadas morfologicamente por microscopia de luz. Os resultados obtidos em citometria de fluxo, juntamente com a análise morfológica foram utilizados para confirmação do efeito da SBA-15 sobre a viabilidade ou morte celular.

\subsection{Marcação de células para análise por citometria de fluxo}

Camundongos BALB/c, fêmeas, de 6 a 8 semanas de idade imunizados ou não com vacina contra Hepatite $A$; vacina contra Hepatite $A$ em SBA-15; HGG; HGG em SBA-15; $\mathrm{HGG}$ em $\mathrm{Al}(\mathrm{OH})_{3}$; ou inoculados com SBA-15 foram sacrificados e os linfonodos inguinais e periaórticos foram retirados e colocados em placa de 24 poços contendo Colagenase tipo IV [Sigma-Aldrich Biotechnology Co., St. Louis, MO, EUA] na concentração de $2 \mathrm{mg} / \mathrm{mL}$ em meio RPMI 1640 na ausência de SFB. As placas foram mantidas em estufa a $37^{\circ} \mathrm{C}$ contendo $5 \%$ de $\mathrm{CO}_{2}$ e $96 \%$ de umidade por 30 minutos. Após incubação, preparou-se as suspensões celulares utilizando homogeneizador estéril em meio RPMI 1640, centrifugou-se por 5 minutos a $1400 \mathrm{rpm}$ a $4{ }^{\circ} \mathrm{C}$ e ressuspendeu-se em $5 \mathrm{~mL}$ de meio RPMI 1640. Para sedimentação dos grumos, mantiveram-se as células em gelo por 10 minutos. Em seguida, transferiu-se para um novo tubo, $5 \mathrm{~mL}$ das suspensões e a concentração e viabilidade celular foi determinada por contagem em câmara de Neubauer, utilizando azul de Tripan 0,2\%.

As suspensões celulares foram distribuídas em placas de 96 poços de fundo em $U$ na concentração de $1 \times 10^{6}$ células/poço. Para impedir as ligações inespecíficas, incubou-se as suspensões celulares com anticorpo anti-receptor Fc $\gamma$ RII/RIII [10 $\mu \mathrm{L} / 10^{6}$ células] por 30 minutos a $4{ }^{\circ} \mathrm{C}$, centrifugou-se e ressuspendeu-se em meio RPMI sem SFB. Em seguida, avaliaram-se as expressões de marcadores celulares e de moléculas envolvidas com a apresentação antigênica. Para isto, as células foram incubadas com anticorpos monoclonais anti-CD11b, anti-CD11c, anti-CD4, anti-MHC-II $\left[\mathrm{l}-\mathrm{A}^{\mathrm{d}}\right]$ de camundongo marcado com isotiocianato de fluoresceína [FITC], anti-CD8, anti- 
B220, anti-CD40, anti-CD80, anti-CD86-ficoeritrina [PE] de camundongo na concentração de 0,5 a $1 \mu \mathrm{g} / 10^{6}$ células [BD Biosciences, San Jose, CA, EUA] em meio de cultura RPMI por 30 minutos a $4{ }^{\circ} \mathrm{C}$. Em todos os experimentos, amostras de células foram incubadas com anticorpo controle isotípico IgG2a de rato marcado com FITC ou PE.

Em outro experimento teve-se o objetivo de analisar a expressão das moléculas coestimuladoras nas populações de células CD11b, CD11c ou B220. Para tanto, as suspensões celulares foram incubadas com anticorpos antiCD11b-FITC, anti-CD11C-FITC ou anti-B220-FITC simultaneamente com os anticorpos anti-CD40, anti-CD80 ou anti-CD86-PE por 30 minutos a $4{ }^{\circ} \mathrm{C}$. Para a determinação dos parâmetros de leitura das amostras, as suspensões foram incubadas simultaneamente com anticorpos controle isotípicos FITC e PE ou com anticorpos anti-CD4-FITC e anti-CD8-PE.

Após incubação, as células foram lavadas e ressuspensas em PBS contendo paraformaldeído 0,01\% [Merck, Darmstadt, Germany]. As incubações foram feitas em duplicatas e as amostras analisadas em citômetro de fluxo [adquiriu-se $10^{4}$ eventos/amostra] [FacScalibur - Becton \& Dickson, San Jose, CA, EUA]. Os resultados foram expressos em média da intensidade de fluorescência \pm desvio-padrão ou porcentagem de células positivas para os determinados marcadores celulares e são representativos de 2 ou 3 experimentos realizados independentemente.

\subsection{Separação de células CD11c positivas [CD11c ${ }^{+}$]}

Células $\mathrm{CD}_{11 \mathrm{c}^{+}}$foram obtidas a partir de linfonodos inguinais $\mathrm{e}$ periaórticos de camundongos imunizados ou não pela via subcutânea [base da cauda] com HGG; HGG em SBA-15 ou HGG em Al(OH) $)_{3}$. No $5^{\circ}$ dia pósimunização, preparou-se as suspensões celulares conforme descrito na seção 3.9. Após obtenção dessas suspensões, as células $\mathrm{CD}_{11 \mathrm{C}^{+}}$foram purificadas por seleção positiva através do sistema MidiMACS [Miltenyi Biotec].

As suspensões celulares foram ajustadas para $1 \times 10^{8}$ células $/ \mathrm{mL}$ e incubadas por 30 minutos a $4{ }^{\circ} \mathrm{C}$ com anticorpo monoclonal anti-CD11c ligado à microesferas magnéticas [Miltenyi Biotec Inc., Auburn, CA, USA] na concentração de $100 \mu \mathrm{L} / 10^{8}$ células. Após incubação, acrescentou-se às 
células $5 \mathrm{~mL}$ de tampão PBS contendo 0,5\% de BSA-EDTA $2 \mathrm{mM} \mathrm{pH} \mathrm{7,2} \mathrm{e}$ centrifugou-se por 5 minutos a $1200 \mathrm{rpm}$ a $10{ }^{\circ} \mathrm{C}$. As suspensões foram ressuspensas em $800 \mu \mathrm{L}$ de tampão PBS contendo 0,5\% de BSA-EDTA 2 mM $\mathrm{pH}$ 7,2 e aplicadas na coluna MidiMACS acoplada ao campo magnético. As células não marcadas com as esferas-magnéticas da coluna foram lavadas da coluna com a aplicação de $5 \mathrm{~mL}$ de tampão. Em seguida, retirou-se a coluna do campo magnético e as células $\mathrm{CD}_{11 \mathrm{c}^{+}}$foram eluídas com a aplicação de 5 $\mathrm{mL}$ do tampão à coluna.

A suspensão celular obtida foi centrifugada a $4{ }^{\circ} \mathrm{C}$ a $1200 \mathrm{rpm}$ por 5 minutos e realizou-se contagem das células. As células $\mathrm{CD}_{11 \mathrm{c}^{+}}$purificadas foram utilizadas para análise da expressão de moléculas MHC-II, CD40, CD80 e CD86 por citometria de fluxo [FacScalibur - Becton \& Dickson, San Jose, CA, EUA]. A pureza das suspensões celulares foi determinada por citometria de fluxo através de análises pelo software Cell Quest [BD Bioscience Franklin Lakes, NJ, USA] e foi de aproximadamente 90 - 93\%. A pureza das suspensões do grupos HGG:SBA-15 e HGG:Al(OH) $)_{3}$ foi similar.

\subsection{Cultivo de células linfóides estimuladas com antígenos ou mitógeno para obtenção dos sobrenadantes}

Suspensões celulares foram preparadas a partir de linfonodos inguinais e periaórticos de camundongos BALB/c imunizados ou não com HGG,

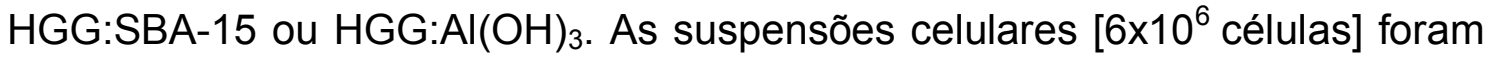
distribuídas em placas de 24 poços e incubadas com meio RPMI-S, HGG [250 $\mu \mathrm{g} / \mathrm{mL}$ ] ou ConA [4,0 $\mu \mathrm{g} / \mathrm{mL}$ ] em estufa com 5\% $\mathrm{CO}_{2}$ umidificada por 48 horas. Após este período, as placas contendo as culturas foram centrifugadas a $4{ }^{\circ} \mathrm{C}$ a $1200 \mathrm{rpm}$, os sobrenadantes coletados, aliquotados e congelados para posterior detecção das citocinas. 


\subsection{ELISA}

\subsubsection{Determinações dos títulos de anticorpos lgG, IgG1 e lgG2a}

Os títulos de anticorpos lgG e isótipos lgG1 e lgG2a foram determinados pelo teste de ELISA (ENGVALL; PERLMAN, 1971). As dosagens foram realizadas em microplacas com 96 poços [Nunc] com propriedade de alta ligação, sensibilizadas com a vacina da Hepatite A ou com HGG diluídas em tampão carbonato-bicarbonato [1 $\mu \mathrm{g} / \mathrm{mL}$ ], por 18 horas a $4{ }^{\circ} \mathrm{C}$. Após este período inicial de incubação, as placas foram lavadas 3 vezes com tampão PBS contendo Tween a 0,05\% [PBS-T]. Seguiu-se bloqueio com 0,5\% de gelatina no diluente PBS-Tween [gelatina-PBS-T] por 2 horas a $37{ }^{\circ} \mathrm{C}$. A seguir, as amostras foram distribuídas e diluídas em série na solução diluente, e incubadas durante 1 hora a $37^{\circ} \mathrm{C}$; as placas foram novamente lavadas 3 vezes em PBS-T e $100 \mu \mathrm{L}$ dos anticorpos anti-IgG [Sigma-Aldrich Biotechnology Co., St. Louis, MO, EUA] [1:30.000]; anti-IgG1 [BD Pharmingen $^{\mathrm{TM}}$ - BD Bioscience, San Diego, CA, EUA] [1:400]; anti-IgG2a [BD Pharmingen $^{\mathrm{TM}}$ - BD Bioscience, San Diego, CA, EUA] [1:1000] marcados com peroxidase diluídos em gelatina-PBS-T foram adicionados $\mathrm{e}$ as placas incubadas durante 1 hora a $37^{\circ} \mathrm{C}$; após lavagem 3 vezes em PBS-T, $100 \mu \mathrm{L}$ do tampão substrato [20 mg OPD diluído em $40 \mathrm{~mL}$ de tampão citrato/fosfato/ $\mathrm{H}_{2} \mathrm{O}_{2}$ $0,3 \%$ ] foi adicionado; as placas foram mantidas no escuro até a reação ser revelada. A reação foi interrompida com $50 \mu \mathrm{L} /$ poço de ácido cítrico a 0,2 M. A leitura foi realizada em $\lambda$ de $450 \mathrm{~nm}$ utilizando-se o ELISA Multiskan Labsystems. Os títulos foram estabelecidos desprezando-se $20 \%$ do valor da absorbância da diluição de saturação e expressos em $\log _{2}$.

\subsubsection{Quantificação de citocinas}

Os níveis de IL-2, IL-4, IL-5, IL-10, IL-12, IL-13 e de IFN- $\gamma$ foram determinados nos sobrenadantes das suspensões celulares de linfonodos inguinais e periaórticos dos animais imunizados com HGG; HGG em SBA-15; HGG em $\mathrm{Al}(\mathrm{OH})_{3}$; ou apenas inoculados com SBA-15. As dosagens foram 
realizadas pelo método de ELISA sanduíche, empregando kits [R\&D Systems Inc., Minneapolis, MN, USA; BD Biosciences, San Jose, CA, EUA; Pharmigen, San Diego, CA, EUA] de acordo com as instruções do fabricante. Assim, placas de 96 poços [Costar] foram sensibilizadas com $50 \mu \mathrm{L}$ do primeiro anticorpo, diluído em tampão bicarbonato de sódio $0,1 \mathrm{M}$, pH 9,6, por 18 horas a $4{ }^{\circ} \mathrm{C}$. Após este período, as placas foram lavadas 3 vezes em tampão PBS contendo 0,05\% de Tween-20 [PBS-T] e submetidas a bloqueio dos sítios não cobertos pelo anticorpo de captura com tampão PBS acrescido de $10 \%$ de soro fetal bovino [SFB] por 1 hora a temperatura ambiente [TA]. Em seguida, foi adicionado $50 \mu \mathrm{L}$ das respectivas citocinas recombinantes ou amostras nas diluições adequadas. As placas foram incubadas por 2 horas/TA e após este período, foram novamente lavadas 3 vezes em PBS-T e $50 \mu \mathrm{L}$ do segundo anticorpo biotinilado foi adicionado as placas por mais 1 hora/TA. Em seguida, acrescentou-se a estreptoavidina marcada com peroxidase - [Amersham Biosciences, Piscataway, NJ, EUA] e incubou-se por 1 hora/TA. Por último, as placas foram lavadas 3 vezes em PBS-T e cada poço recebeu $100 \mu \mathrm{L}$ de solução contendo o substrato $\mathrm{H}_{2} \mathrm{O}_{2} 3 \%$ [v/v] e OPD. A reação foi interrompida com adição de $50 \mu \mathrm{L}$ de ácido sulfúrico $2 \mathrm{~N}$. As leituras foram feitas a 450 ou 492 nm utilizando-se o ELISA Multiskan - Labsystems. A concentração das diferentes citocinas presentes nos sobrenadantes das culturas foi calculada a partir de curvas padrão estabelecidas a partir das citocinas recombinantes diluídas na razão 1:2 [100 pg/mL de IL-2; $10 \mathrm{ng} / \mathrm{mL}$ de IL-4; $10 \mathrm{ng} / \mathrm{mL}$ de IL-5; $2 \mathrm{ng} / \mathrm{mL}$ de IL-10; $6 \mathrm{ng} / \mathrm{mL}$ de IL-12, $5 \mathrm{ng} / \mathrm{mL}$ de IL-13; 4 ng/mL de IFN- $\gamma]$.

\subsection{Ensaio in vitro de resposta proliferativa de linfócitos T}

Grupos de camundongos BALB/c foram imunizados pela via subcutânea [base da cauda] com HGG; HGG:SBA-15 ou HGG:Al(OH) 3 . No $10^{\circ}$ dia pósimunização, os animais foram sacrificados e as suspensões celulares preparadas a partir dos linfonodos inguinais e periaórticos dos diferentes grupos experimentais foram distribuídas em placas de 96 poços na concentração de $2 \times 10^{5}$ células/poço em meio de cultura RPMI [Invitrogen] suplementado com $2 \mathrm{mM}$ de L-glutamina, $50 \mu \mathrm{M}$ de $2-\mathrm{ME}$ e $5 \%$ de soro fetal 
bovino [SFB]. A proliferação celular foi induzida pela adição de $500 \mu \mathrm{g} / \mathrm{mL}$ de HGG ou Con $A[2,0 \mu \mathrm{g} / \mathrm{mL}]$ às culturas. Amostras de células mantidas em meio de cultura RPMI foram utilizadas como controle. As culturas foram mantidas por 48 ou 96 horas $/ 37{ }^{\circ} \mathrm{C}$ em estufa de $5 \%$ de $\mathrm{CO}_{2}$ umidificada. Após incubação, avaliou-se a resposta proliferativa dos linfócitos $\mathrm{T}$ utilizando-se o Kit "Cell proliferation ELISA Biotrak System version 2 [Armersham GE Healthcare, Little Chalfont, Buckinghamshire, HP7 9NA, UK]. A reação resultante foi interrompida com $25 \mu \mathrm{L} /$ poço da solução de ácido Sulfúrico $1 \mathrm{M}$ e lida a $450 \mathrm{~nm}$ em espectrofotômetro. Os resultados foram expressos como a média da densidade óptica obtida das amostras em triplicata \pm desvio padrão. Os resultados são representativos de 2 experimentos.

\subsection{Análise estatística}

A análise da significância dos resultados de produção de anticorpos foi estabelecida através do teste $t$ de Student considerando-se a probabilidade mínima de $p \leq 0,05$. Entretanto, para as análises do recrutamento de células para os linfonodos, bem como a expressão de moléculas coestimuladoras, produção de citocinas e proliferação celular foi utilizado o teste de análise da variância Two-Way ANOVA [significância mínima de $p \leq 0,05$, seguido pelo pós-teste de Bonferroni para comparação e determinação da origem da diferença entre os grupo]. 


\section{RESULTADOS}

\subsection{Efeito in vitro da sílica SBA-15 sobre macrófagos obtidos de camundongos LIII, LIVA $_{\text {e SWISS }}$}

Estudos realizados por ocasião do Mestrado demonstraram que a SBA-15 foi capaz de modular positivamente a resposta imune humoral dos camundongos $L$ das Seleções III e IVA, eliminando as diferenças fenotípicas interlinhagens $\mathrm{H}-\mathrm{L}$. Diante desses resultados foi avaliado o efeito dessa nanopartícula na morfologia e atividade fagocítica de macrófagos derivados da medula óssea de camundongos Swiss, $L_{\text {III }}$ e $L_{\text {IVA. Diferentes }}$ concentrações de SBA-15 [20; 50 e $100 \mu \mathrm{g} / \mathrm{mL}]$ foram adicionadas às culturas; nas condições testadas, a SBA-15 não causou alteração morfológica ou morte celular, e as células mantiveram-se íntegras até 96 horas de cultura (Figura 2). Ainda, altas concentrações dessa sílica [200 - $1000 \mu \mathrm{g} / \mathrm{mL}$ ] não modificaram a integridade celular; no entanto, concentrações entre $1,5-5 \mathrm{mg} / \mathrm{mL}$ reduziram a viabilidade celular, mas não alteraram a atividade fagocítica dos macrófagos. 


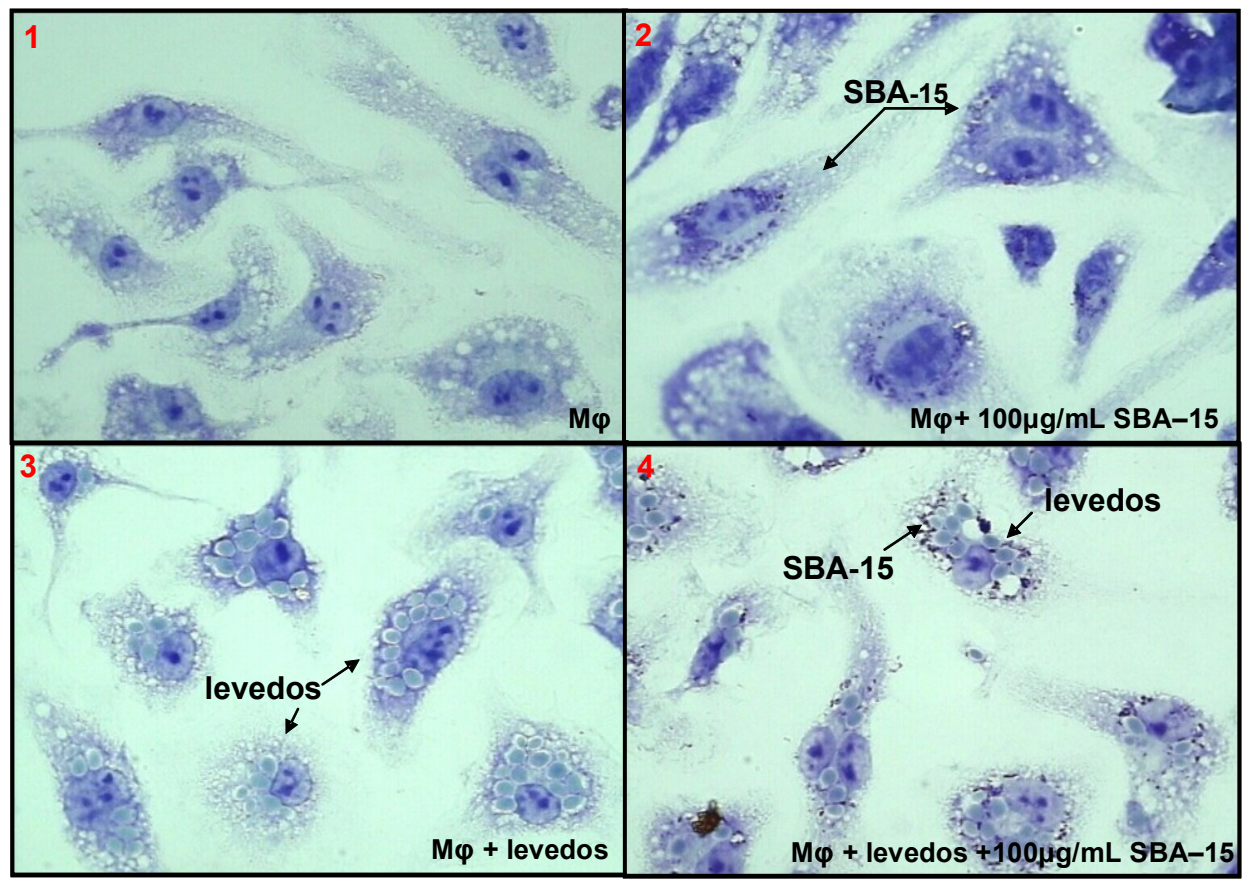

Figura 2 - Efeito da SBA-15 na morfologia de macrófagos. Microscopia de luz da morfologia e atividade fagocítica de macrófagos derivados da medula óssea de camundongos $L_{\text {III }}$ após 24 horas de cultura [1- controle - só $M \varphi$; 2- $M \varphi+100 \mu \mathrm{g} / \mathrm{mL}$ de SBA-15; 3- M $\varphi$ + levedos; $4-\mathrm{M} \varphi$ + levedos + 100 $\mu \mathrm{g} / \mathrm{mL}$ de SBA-15. May-Giemsa. 100x.].

A Figura 3 mostra o aumento proporcional de SBA-15 internalizada e do número de vacúolos nos $M \varphi$ da linhagem $L_{\text {III }}$ após incubação com 200, 500 ou $1000 \mu \mathrm{g} / \mathrm{mL}$ de sílica. O mesmo foi observado em macrófagos derivados de camundongos LIVA e Swiss [dados não mostrados]. 


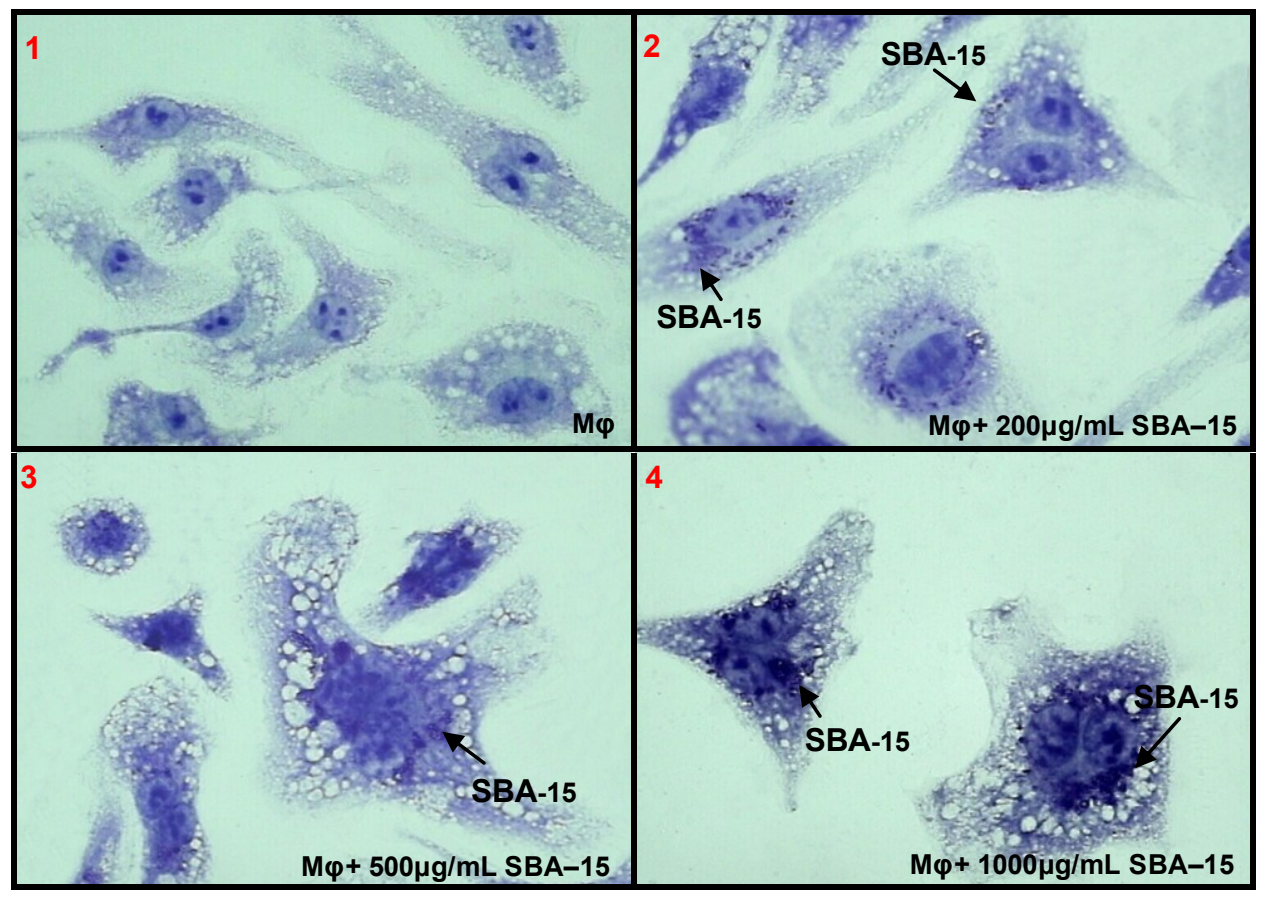

Figura 3 - Morfologia dos macrófagos de camundongos $L_{\text {III }}$ após 24 horas de incubação com SBA-15. 1- Controle - só $M \varphi ; 2-M \varphi+200 \mu \mathrm{g} / \mathrm{mL}$ de SBA-15; 3- $M \varphi+500 \mu \mathrm{g} / \mathrm{mL}$ de SBA-15; $4-M \varphi+1000 \mu \mathrm{g} / \mathrm{mL}$ de SBA15 analisados por meio de microscopia de luz. Coloração com MayGiemsa.100x.

Para avaliação do efeito dessa partícula nanoestruturada sobre a atividade fagocítica e catabólica de macrófagos, Saccharomyces cerevisae foram adicionados na proporção de 3 levedos para cada célula e após 1hora de incubação [pulso de infecção] as células foram lavadas e fixadas em diferentes tempos $[1 ; 24 ; 48 ; 72$ e 96 horas]. A porcentagem de $M \varphi$ infectados e o número de levedos internalizados por macrófago foram analisados.

Análise do potencial fagocítico e porcentagem de macrófagos infectados de camundongos $L_{\text {III }}$ e Swiss após 1 hora de incubação com 200, 500 ou $1000 \mu \mathrm{g} / \mathrm{mL}$ de SBA-15 não indicaram diferença em relação ao grupo controle [só levedos]. Em L III esse padrão persistiu até 24 horas de incubação, entretanto, após 48 e 72 horas de cultura, a porcentagem de infecção reduziu 15\% nos grupos tratados com diferentes concentrações de sílica quando comparados ao controle (Figura 4A). Por outro lado, cultura de 24 horas de macrófagos de Swiss tratados com SBA-15 apresentaram menor porcentagem de infecção relativamente ao grupo controle [cerca de $9 \%$ após incubação com 
200 ou $500 \mu \mathrm{g} / \mathrm{mL}$ de SBA-15 e 23\% com $1000 \mu \mathrm{g} / \mathrm{mL}$ de sílica]. Para o grupo tratado com $1000 \mu \mathrm{g} / \mathrm{mL}$ de SBA-15 a diferença foi de 20\% até 48 horas de cultura e com 72 horas de incubação não se observou diferença entre os grupos (Figure 4B).

Verificou-se o catabolismo através do monitoramento do número de levedos por macrófagos até 72 horas de infecção. No período analisado [24 a 72 horas de cultura], o número de levedos por células de camundongos $L_{\text {III }} \mathrm{e}$ Swiss tratados com diferentes concentrações de SBA-15 diminuiu tanto quanto no grupo controle (Figura 4C e 4D). Esses resultados mostram que diferentes concentrações de SBA-15 [200 - $1000 \mu \mathrm{g} / \mathrm{mL}$ ] não interferem na atividade fagocítica e catabólica de macrófagos derivados de diferentes linhagens de camundongos. 
4)

A)

$\mathrm{L}_{\text {III }}$

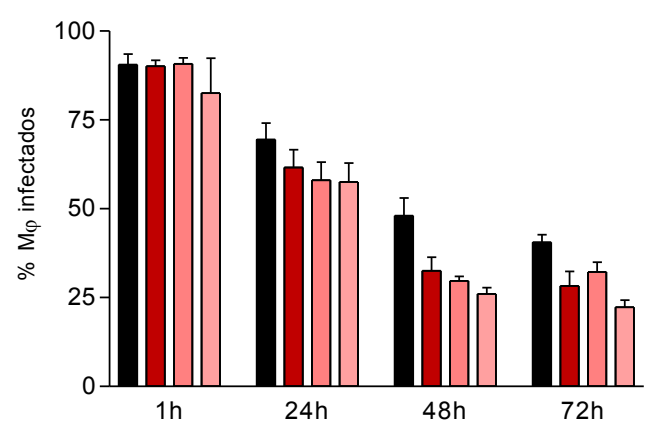

C)

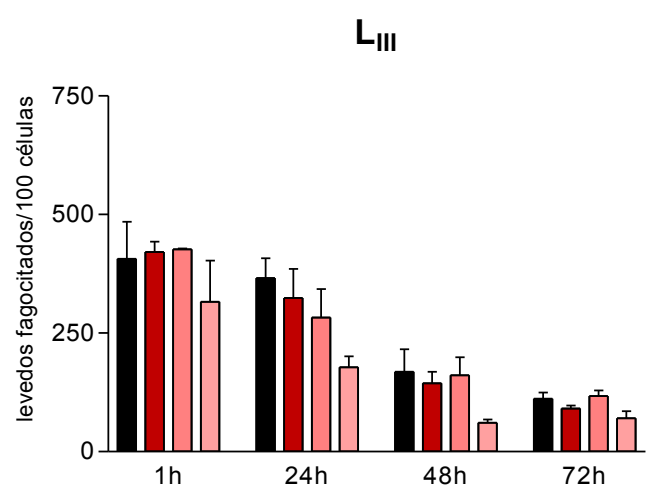

B)

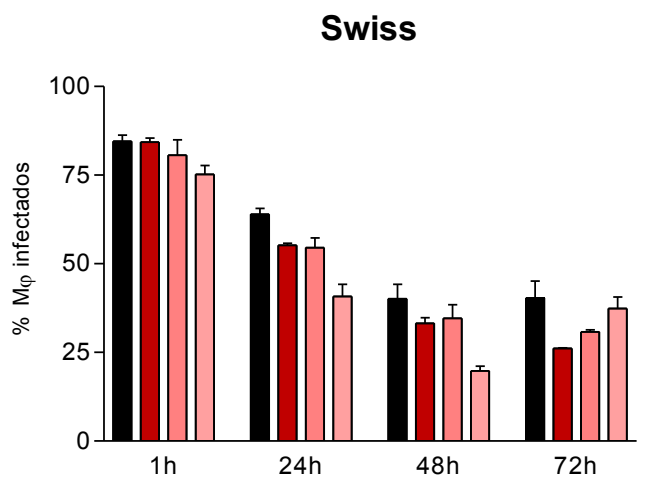

D)

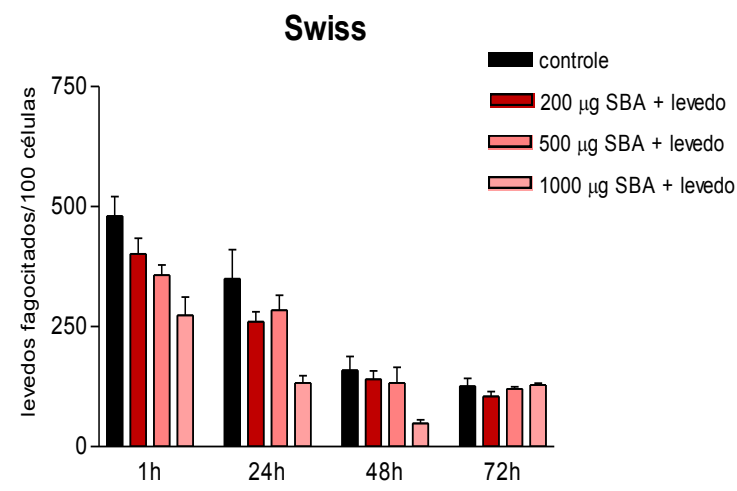

Figura 4 - Efeito da SBA-15 na fagocitose e atividade catabólica de macrófagos derivados da medula óssea de camundongos $L_{\| I I}$ e Swiss. Porcentagem de macrófagos infectados após 1 - 72 horas de incubação com diferentes concentrações de SBA-15 [200 -1000 $\mu \mathrm{g} / \mathrm{mL}]+$ levedos ou somente com levedos [grupo-controle] em camundongos $L_{\text {III }}[A]$ ou Swiss $[B]$. Números de levedos fagocitados após 1 - 72 horas de incubação com diferentes concentrações de SBA-15 [200 -1000 $\mu \mathrm{g} / \mathrm{mL}]+$ levedos ou somente com levedos [grupo-controle] em camundongos $L_{\text {III }}$ [C] ou Swiss [D]. Esses resultados são representativos da atividade fagocítica de camundongos $L_{\text {IVA }}$ e referem-se a 2 experimentos independentes feitos em triplicata.

\subsection{Viabilidade e necrose celular}

Uma vez que diferentes concentrações de SBA-15 não alteraram a morfologia e capacidade fagocítica de macrófagos derivados da medula óssea de camundongos Swiss, $L_{I I I}$ e $L_{I V A}$, iniciaram-se estudos in vitro sobre a 
viabilidade/necrose celular de macrófagos peritoneais após incubação por 24 horas com 50, 100, 200 ou $1500 \mu \mathrm{g} / \mathrm{mL}$ de SBA-15.

A quantificação da morte celular após tratamento dos macrófagos com $50 \mu \mathrm{g} / \mathrm{mL}$ de SBA-15 mostra que $7 \%$ das células estão marcadas com PI e esta marcação aumenta para cerca de 25\% após incubação com 100 ou 200 Mg/mL de sílica. Nota-se que macrófagos não tratados apresentaram cerca de $4 \%$ de necrose/morte celular. Já, no tratamento com $1500 \mu \mathrm{g} / \mathrm{mL}$ de SBA-15 quase $60 \%$ de células encontram-se não viáveis (Figura 5).

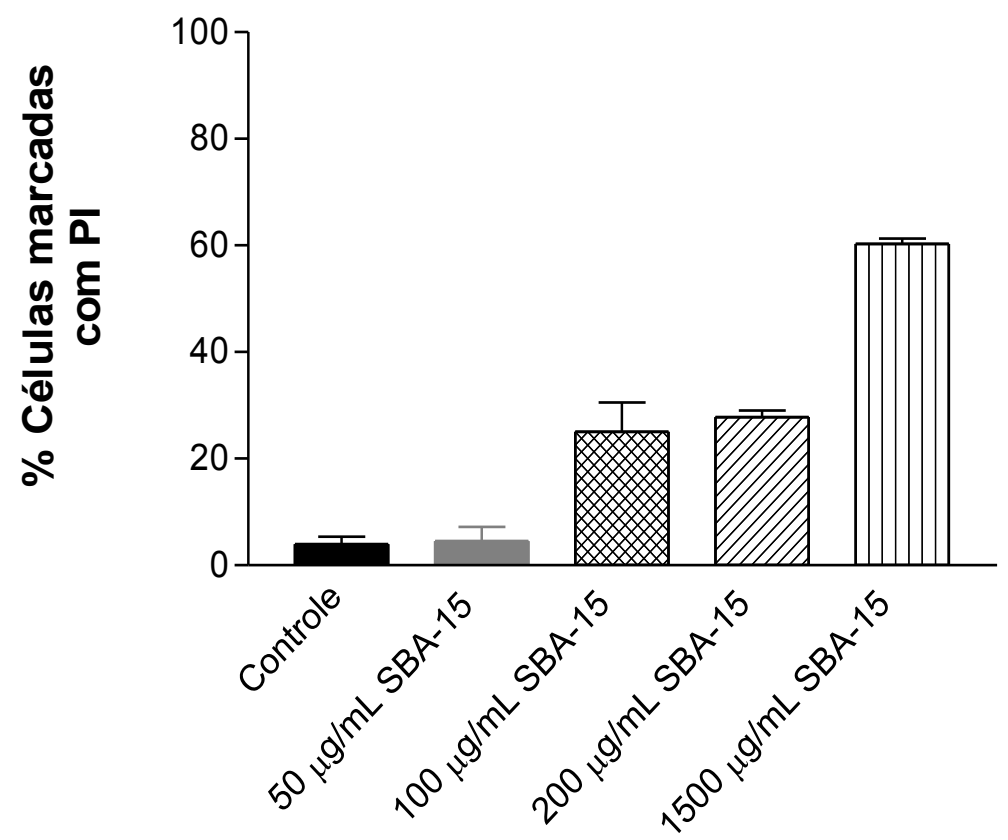

Figura 5 - Efeito da sílica SBA-15 na viabilidade celular. Análise por citometria de fluxo da porcentagem de células peritoneais de camundongos BALB/c marcadas com iodeto de propídio após incubação por 24 horas com $50-1500 \mu \mathrm{g} / \mathrm{mL}$ de SBA-15.

\subsection{Imunização com vacina contra Hepatite A}

Seguindo-se os estudos comparativos do efeito da SBA-15 com outros adjuvantes, camundongos da linhagem $L_{\text {III }}$ [n=3/grupo] foram imunizados pela via intramuscular com 0,48 $\mu \mathrm{g} / \mathrm{animal}$ da vacina contra Hepatite A [Hep-A] adsorvida em $12 \mu \mathrm{g} / \mathrm{animal}$ de SBA-15 [v/v], ou adsorvida em $12 \mu \mathrm{g} / \mathrm{animal}$ de 
$\mathrm{Al}(\mathrm{OH})_{3}[\mathrm{v} / \mathrm{v}]$ em volume final de $200 \mu \mathrm{L}$. O grupo controle recebeu 0,48 $\mu$ g/animal da vacina em PBS. Para análise da resposta secundária, 160 dias após a primeira imunização, os animais receberam 0,48 $\mu \mathrm{g} / \mathrm{animal}$ da vacina adsorvida em $12 \mu \mathrm{g}$ de SBA-15. Realizou-se sangria pelo plexo retroorbital nos $15^{\circ}, 40^{\circ}, 145^{\circ}$ dias da resposta primária e nos $10^{\circ}$ e $40^{\circ}$ dias da resposta secundária.

Conforme ilustrado na Figura 6, tanto na resposta primária, quanto na secundária não houve diferença nos títulos de anticorpos IgG produzidos entre os grupos experimentais. No entanto, a segunda imunização com vacina adsorvida em SBA-15 induziu no grupo primado com vacina em PBS aumento de cerca de 4 vezes nos títulos de anticorpos. Para os outros grupos não houve aumento nos títulos de lgG após segunda imunização.

Vale salientar que esta vacina utilizada nas imunizações continha na sua composição $\mathrm{Al}(\mathrm{OH})_{3}$ [Merck \& Co., Inc., Whitehouse Station, NJ, EUA].

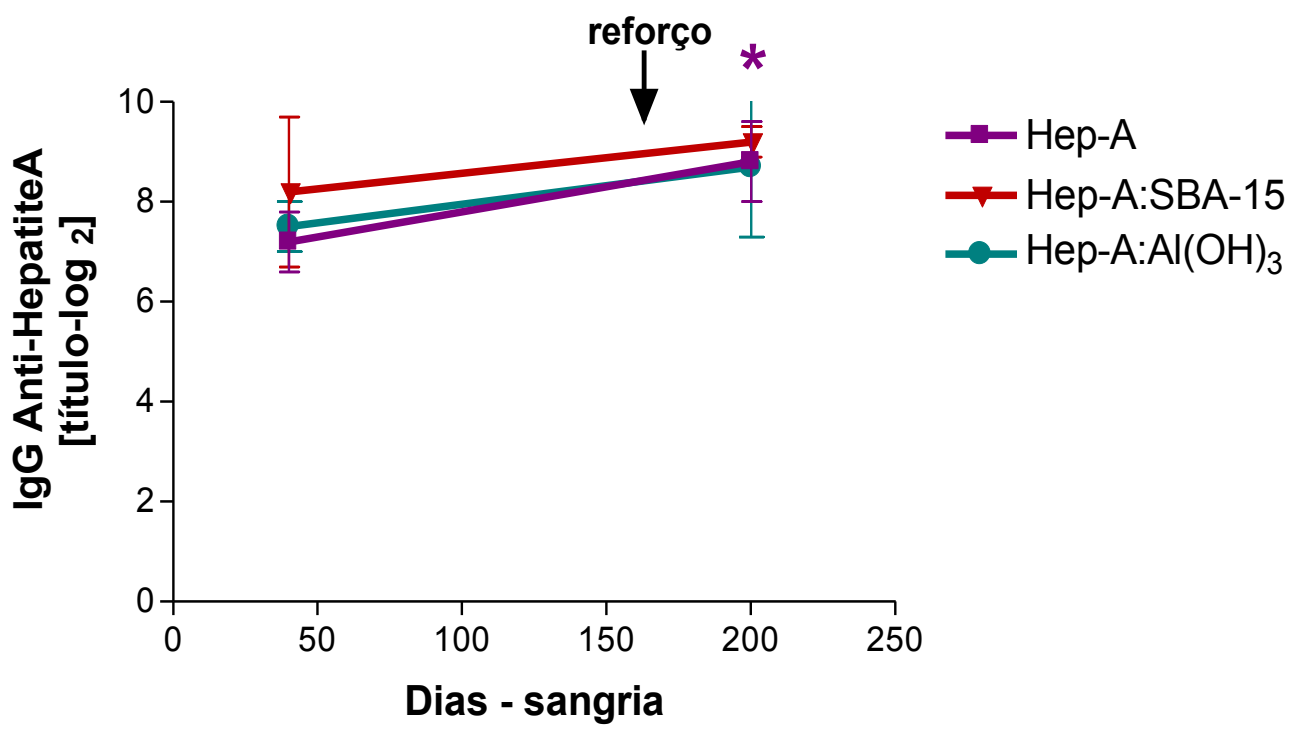

Figura 6 - Títulos de lgG anti-hepatite $A$ produzidos por camundongos $L_{\text {III. }}$ Camundongos $L_{\text {III }}[n=3 / g r u p o]$ foram imunizados pela via intramuscular com $0,48 \mu \mathrm{g} / \mathrm{animal}$ da vacina contra Hepatite $\mathrm{A}$ adsorvida em $12 \mu \mathrm{g} /$ animal de SBA-15 ( $\boldsymbol{\nabla})$; ou em $12 \mu \mathrm{g} /$ animal $\mathrm{Al}(\mathrm{OH})_{3}(\bullet)$;ou em PBS ( $\bullet$ ). Anticorpos foram detectados pelo método de ELISA nos $40^{\circ}$ dia da primeira imunização. No $160^{\circ}$ dia realizou-se segunda imunização e os antissoros foram analisados no $200^{\circ}$ dias $\left[^{\star} p<0,05-\right.$ diferença entre RP e RS do grupo Hep-A - teste $t$ de Student]. Os resultados foram expressos como a média dos títulos obtidos dos 3 animais/grupo \pm desvio-padrão. 


\subsubsection{Avaliação do tempo de contato imunógeno:SBA-15 e potencialização da adsorção}

Dada a eficácia desta sílica em potencializar a resposta imune humoral contra diversos imunógenos e, seguindo os resultados físico-químicos previamente obtidos no Laboratório de Cristalografia do Instituto de Física da USP sobre a incorporação da soro albumina bovina [BSA] à SBA-15, que indicaram que o tempo de contato imunógeno:SBA-15 potencializa sua encapsulação/adsorção, realizou-se estudos sobre a produção de anticorpos relativamente ao tempo de contato da vacina contra Hepatite A em SBA-15. Assim, camundongos da linhagem $L_{\text {III }}$ [n=5/grupo] foram imunizados pela via subcutânea com $200 \mu \mathrm{L}$ da vacina contra Hepatite $A$ [0,48 $\mu$ g/animal] adsorvida ou não em $12 \mu \mathrm{g}$ de SBA-15 [v/v] durante 30 dias antes da imunização [HepA:SBA-15 30d] ou adsorvida no momento da imunização [Hep-A:SBA-15 0h]. As sangrias foram realizadas nos $10^{\circ}, 30^{\circ}, 50^{\circ}, 150^{\circ}$ dias da resposta primária e nos $10^{\circ}$ e $30^{\circ}$ dias da resposta secundária.

Pela Figura 7 verifica-se no $30^{\circ}$ dia da resposta primária que, em relação ao grupo primado somente com a vacina, o grupo Hep-A:SBA-15 Oh induziu títulos de anticorpos cerca de 4 vezes superiores [ $p<0,01]$ e, para o grupo Hep-A:SBA-15 30d essa diferença foi $\sim 8$ vezes [p $<0,001]$. Durante a resposta primária não se observou diferença entre a vacina adsorvida a SBA-15 por Oh e 30 dias. Nota-se que no $10^{\circ}$ dia após dose-reforço houve aumento nos títulos de lgG anti-hepatite $A$ em todos os grupos experimentais comparativamente aos pré-existentes no $150^{\circ}$ dia da resposta primária. $O$ tempo de contato Hep-A:SBA-15 parece ter influenciado nessa sensibilização secundária, pois houve aumento de cerca de 32 vezes nos títulos de anticorpos do grupo primado com Hep-A:SBA-15 30d, enquanto no grupo primado com Hep-A:SBA-15 0h esse aumento foi de $\sim 8$ vezes e para o primado somente com a vacina esse foi de 16 vezes (Figura 7). No $10^{\circ}$ dia da resposta secundária há uma diferença de $\sim 3 \log 2$ entre os títulos de lgG produzidos pelo grupo primado com Hep-A:SBA-15 30d relativamente ao grupo Hep-A:SBA-15 0h e ao que recebeu somente a vacina [p $<0,001]$. Os títulos de anticorpos secundários mantiveram-se elevados até $030^{\circ}$ dia da resposta 
secundária e nenhuma diferença entre os grupos experimentais foi constatada nesse período (Figura 7).

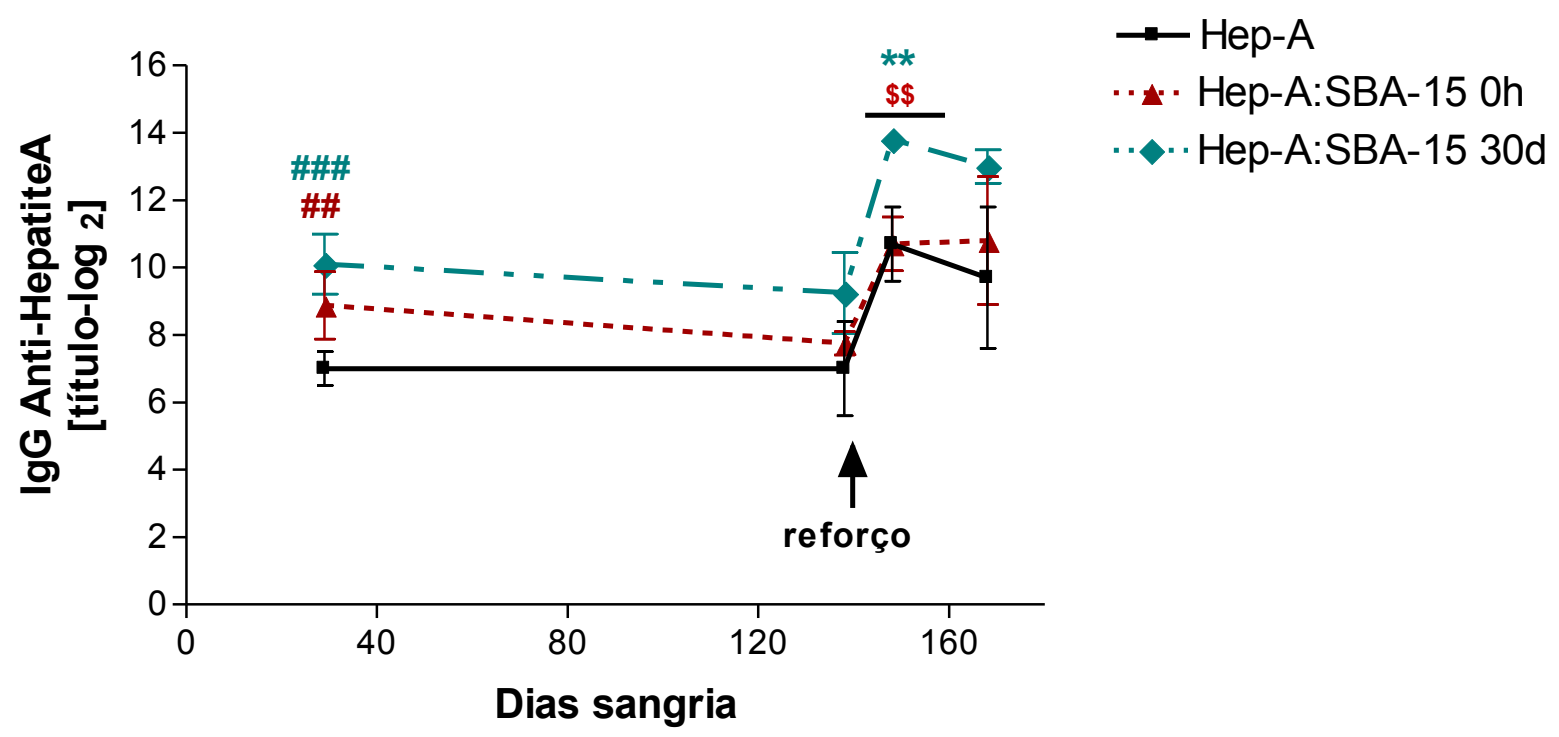

Figura 7 - Comparação dos títulos de $\lg G$ produzidos por camundongos $L_{\text {III }}$ [n=5/grupo] imunizados pela via subcutânea com 0,48 $\mu \mathrm{g} / \mathrm{animal}$ da vacina contra Hepatite A adsorvida em $12 \mu \mathrm{g} /$ animal de SBA-15 [v/v] no momento da imunização [Hep-A:SBA-15 Oh] e/ou 30 dias antes [Hep-A:SBA-15 30d]. Anticorpos anti-Hepatite A foram determinados pelo método de ELISA nos $30^{\circ}, 150^{\circ}, 160^{\circ}$ e $180^{\circ}$ dias após imunização. Os resultados foram expressos como a média dos títulos \pm desviopadrão [ ${ }^{\# \#} p<0,01$; ${ }^{\# \#} p<0,001 ;{ }^{* *} p<0,01$ utilizando-se o grupo Hep-A como referência; $\$ p<0,01$ utilizando-se o grupo Hep-A:SBA-15 Oh como referência nas análises do teste $\mathrm{t}-$ de Student].

A partir desses dados, testaram-se intervalos de tempo intermediários entre 0 e 30 dias; seguindo o protocolo descrito acima, determinaram-se os títulos individuais de anticorpos após imunização com a vacina adsorvida previamente a SBA-15 por 0h, 3, 8 ou 30 dias. Nenhuma diferença foi observada entre os títulos de anticorpos produzidos pelos grupos que receberam a vacina adsorvida nos intervalos acima citados e os níveis mantiveram-se estáveis do $30^{\circ}$ ao $80^{\circ}$ dias da resposta primária [dados não mostrados].

Seguiu-se avaliação da resposta de grupos de camundongos imunizados com a vacina em SBA-15 durante 180 dias. No $30^{\circ}$ dia da resposta 
primária verificou-se níveis de $\lg G$ cerca de 8 vezes inferiores comparativamente aos imunizados com a vacina adsorvida por 30 dias. Por outro lado, a incubação com sílica por 180 dias melhorou a resposta de anticorpos em relação ao grupo que recebeu somente a vacina [diferença de 2 vezes] (Figura 8).

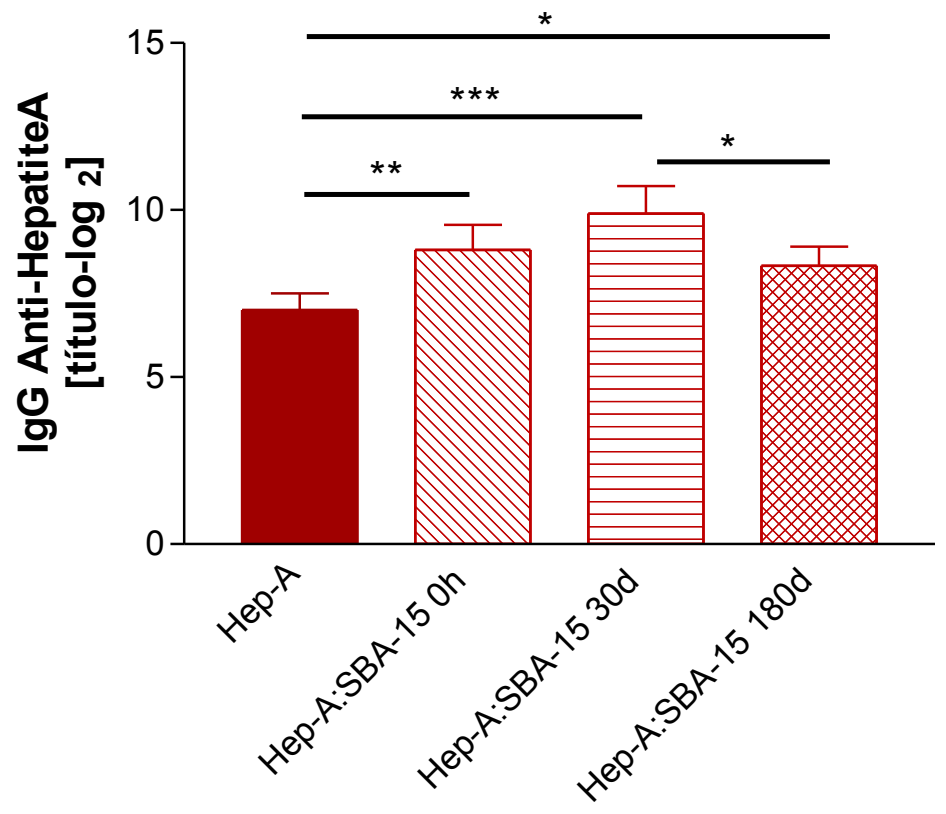

Figura 8 - Comparação dos títulos de lgG produzidos por camundongos $L_{\text {III }}$ [ $\mathrm{n}=5 / \mathrm{grupo}$ ] imunizados pela via subcutânea com $0,48 \mu \mathrm{g} / \mathrm{animal}$ da vacina contra Hepatite A adsorvida em $12 \mu \mathrm{g} / a n i m a l$ de SBA-15 [v/v] durante 0 horas [Hep-A:SBA-15 0h], 30 dias [Hep-A:SBA-15 30d], ou 180 dias [Hep-A:SBA-15 180d]. Anticorpos anti-Hepatite A foram determinados pelo método de ELISA no $30^{\circ}$ dia após imunização. Os resultados foram expressos como a média dos títulos \pm desvio-padrão $\left[{ }^{*} p<0,05 ;{ }^{* *} p<0,01 ;{ }^{* * *} p<0,001-t\right.$ de Student $]$.

4.4 Estudo das populações celulares presentes nos linfonodos de camundongos imunizados com a vacina contra Hepatite $A$ adsorvida ou não em SBA-15

Visto que a adsorção da vacina em SBA-15 potencializou tanto a resposta primária como secundária de anticorpos, iniciaram-se estudos sobre o papel dessa sílica no recrutamento de células para os órgãos linfóides. Para esta finalidade, analisou-se por citometria de fluxo o número de células CD11b ${ }^{+}$ 
$[\mathrm{M} \varphi], \mathrm{CD}_{11 \mathrm{c}^{+}}[\mathrm{DCs}], \mathrm{CD}^{+}, \mathrm{CD}^{+}$e $\mathrm{B}^{220^{+}}$nas suspensões celulares preparadas a partir de linfonodos inguinais e periaórticos de camundongos BALB/c [n=4/grupo] após $01^{\circ}, 3^{\circ}, 5^{\circ}$ e $7^{\circ}$ dia da imunização pela via subcutânea [base da cauda] com a vacina contra Hepatite A [Hep-A]; vacina em SBA-15 [Hep-A:SBA-15] ou inoculados com SBA-15.

Conforme Figura 9 , pode-se verificar no $3^{\circ}, 5^{\circ}$ e $7^{\circ}$ dia pós-imunização aumento no número de células $\mathrm{CD} 11 \mathrm{~b}^{+}, \mathrm{CD} 11 \mathrm{c}^{+}, \mathrm{CD} 4^{+}, \mathrm{CD} 8^{+}$e $\mathrm{B} 220^{+}$nas suspensões obtidas dos camundongos imunizados em relação às de camundongos não-imunizados [ $\left.{ }^{\S} p<0,001\right]$ e, esse aumento foi similar entre os grupos imunizados. Ainda, análise dos resultados obtidos nos diferentes dias pós-imunização indica aumento de todos os tipos celulares no $5^{\circ}$ dia em relação ao obtido no $3^{\circ}$ dia o qual é mantido até o $7^{\circ}$ dia pós-imunização. No $1^{\circ}$ dia pós-imunização não se observa diferença entre os grupos experimentais e o grupo não-imunizado [dados não apresentados].

Salienta-se que devido à problemas ocorridos durante a marcação de células impediram a representação gráfica do grupo SBA-15 no $7^{\circ}$ dia (Figura 9). 


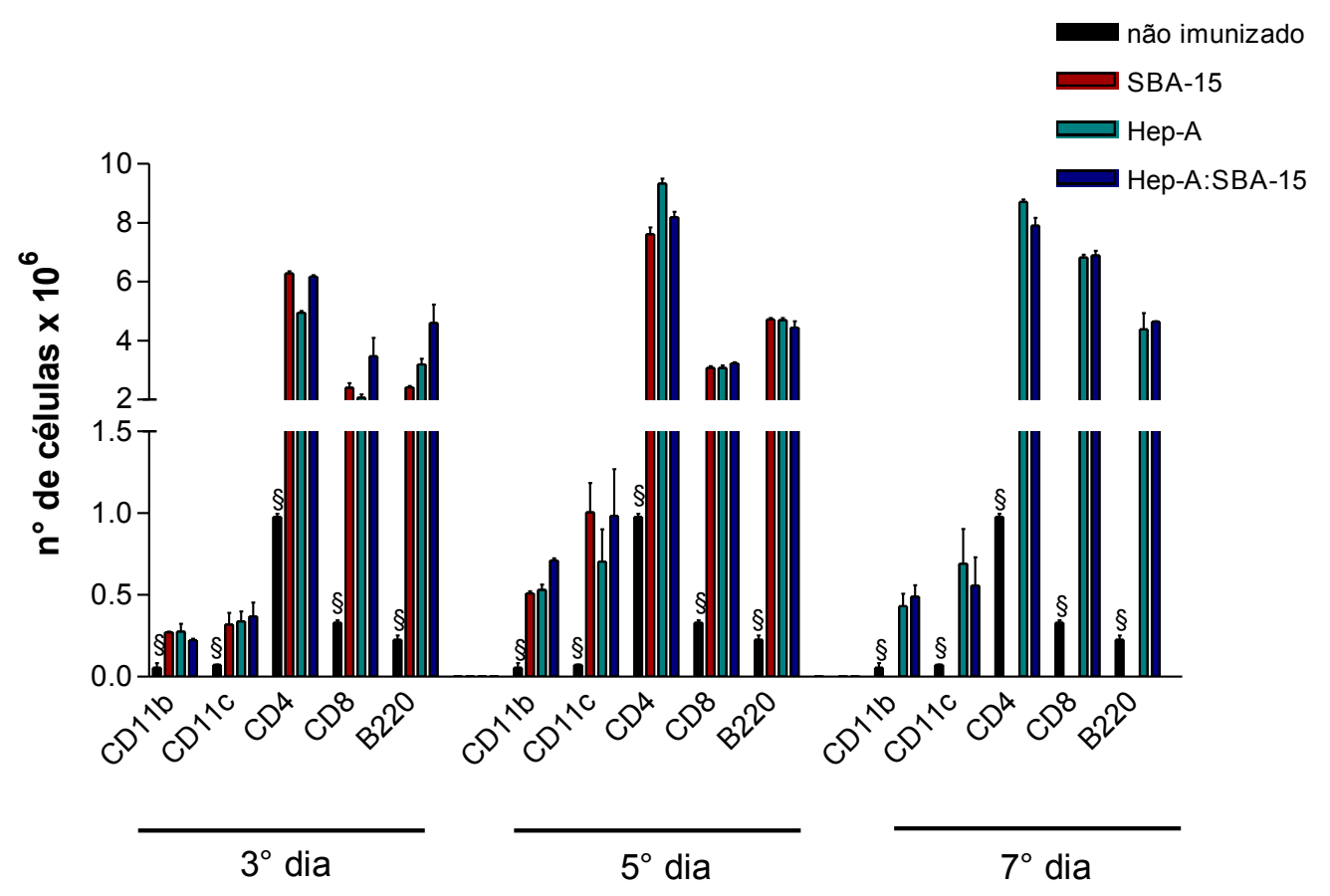

Figura 9 - Número de células $\mathrm{CD} 11 \mathrm{~b}^{+}, \mathrm{CD} 11 \mathrm{c}^{+}, \mathrm{CD} 4^{+}, \mathrm{CD} 8^{+}, \mathrm{B} 220^{+}$presentes nas suspensões celulares de linfonodos inguinais e periaórticos após $3^{\circ}, 5^{\circ} \mathrm{e}$ $7^{\circ}$ dia da imunização de camundongos BALB/c [n=4/grupo] pela via subcutânea [base da cauda] com vacina contra Hepatite A [Hep-A] [ $\square$ ]; vacina em SBA-15 [Hep-A:SBA-15] [ ]; SBA-15 ["] comparativamente aos não imunizados [ $\mathbf{\square}$. Os resultados estão expressos em média \pm desvio padrão do número absoluto de células positivamente marcadas das amostras em duplicata. Os resultados são representativos de 3 experimentos independentes. ${ }^{\S} p<0,001$ grupo não-imunizado comparado ao Hep-A; Hep-A:SBA-15; SBA-15 para cada população celular e dia pós-imunização [Two-way ANOVA - pós-teste de Bonferroni].

\subsubsection{Expressão de moléculas de MHC-II e coestimuladoras após} imunização com a vacina contra Hepatite $A$ adsorvida ou não em SBA-15

Sabendo-se da importância da expressão das moléculas de MHC-II e coestimuladoras na apresentação antigênica e desenvolvimento da imunidade adquirida, estudou-se o efeito da SBA-15 na expressão dessas moléculas. Assim, suspensões celulares de linfonodos periaórticos e inguinais de camundongos BALB/c [n=5/grupo] imunizados com a vacina contra Hepatite $A$ adsorvida ou não em SBA-15 foram incubadas com anticorpos anti-MHC-II, CD40, CD80 e CD86 conjugados em FITC ou PE e analisadas por citometria 
de fluxo. Resultados obtidos com camundongos não imunizados foram utilizados para comparação.

Visto que o maior número de células $\mathrm{CD}_{11} \mathrm{~b}^{+}$e $\mathrm{CD}_{11 \mathrm{c}^{+}}$foi observado no $5^{\circ}$ dia pós-imunização (Figura 9) e, baseando-se nos resultados obtidos por Silva e colaboradores (2006) que demonstram que o pico de expressão das moléculas envolvidas na apresentação antigênica ocorre entre o 4 - $5^{\circ}$ dia pósimunização com ovalbumina [OVA] em Adjuvante Completo de Freund [ACF], seguiu-se análises da expressão dessas moléculas no $5^{\circ}$ dia pós-imunização com Hep-A e Hep-A:SBA-15.

Pelos dados apresentados na Figura 10, verifica-se expressão aumentada de moléculas de MHC-II, CD40, CD80 e CD86 nas células de camundongos imunizados com a vacina adsorvida ou não em SBA-15 em relação às obtidas em camundongos não imunizados [ $\left.{ }^{* * *} p<0,001\right]$. Quanto aos grupos Hep-A e Hep-A:SBA-15, nenhuma diferença foi observada na expressão de CD86; entretanto, nota-se expressão elevada de CD80 nas células do grupo Hep-A:SBA-15 [^•• $p<0,001]$; já, a expressão de MHC-II [\# $p<0,05]$ e CD40 [ $\left.{ }^{\# \#} p<0,01\right]$ foi maior nas células dos camundongos que receberam somente a vacina. 


\section{Não Imunizados}
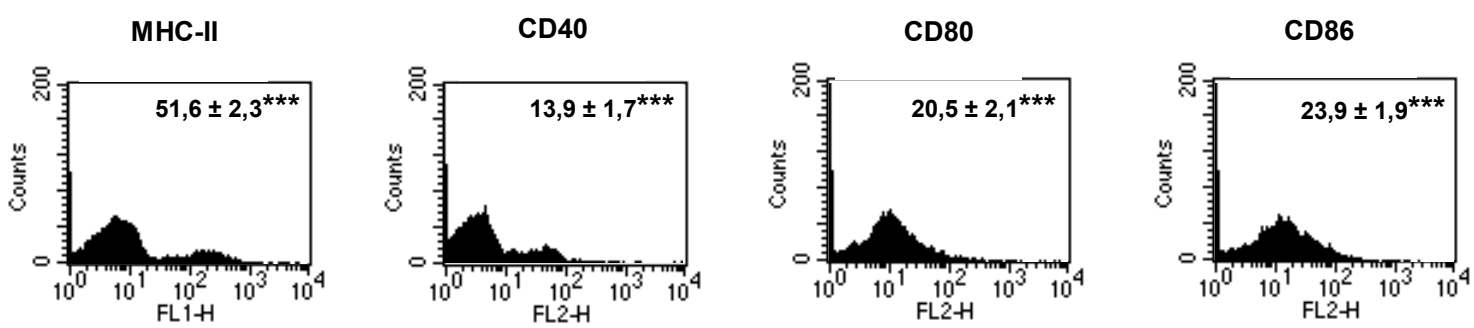

\section{Hep-A}
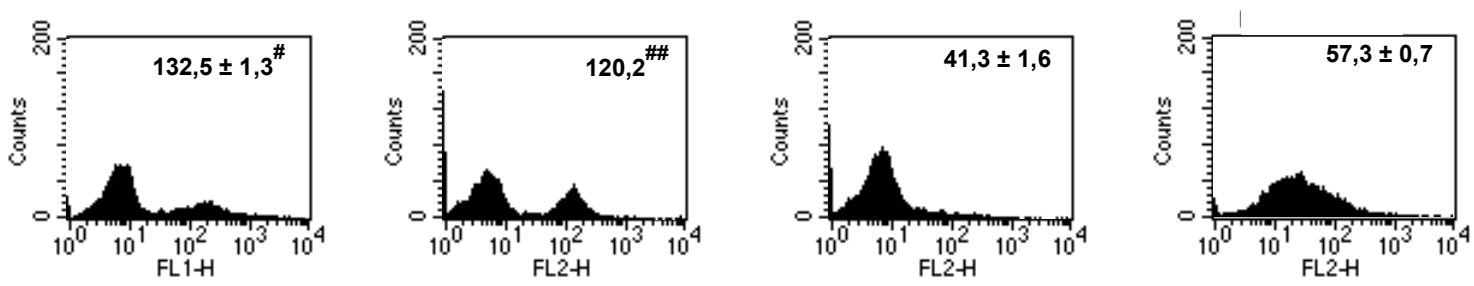

\section{Hep-A:SBA-15}
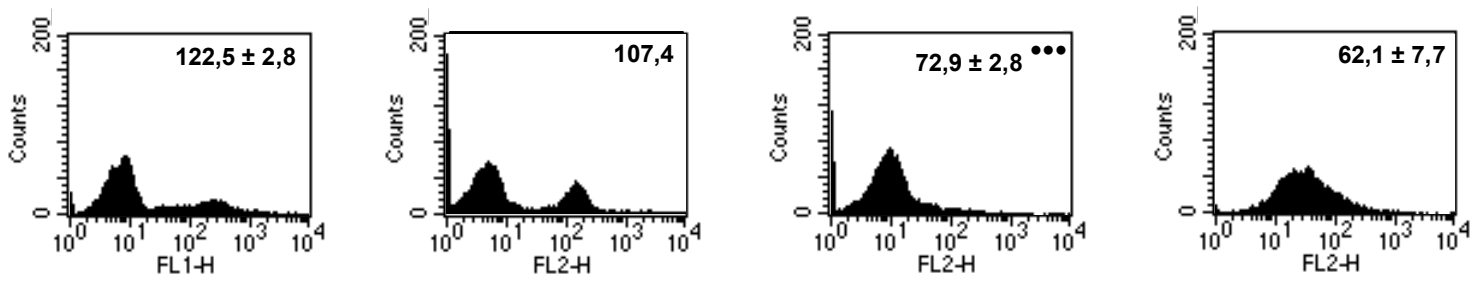

Figura 10 - Expressão das moléculas MHC-II, CD40, CD80 e CD86 nas células de órgãos linfóides após $5^{\circ}$ dia de imunização de camundongos com a vacina contra Hepatite A encapsulada/adsorvida ou não em SBA-15. Camundongos não-imunizados foram utilizados para comparação. Os resultados foram expressos em média de intensidade de fluorescência [MIF] \pm desvio padrão das amostras em duplicata e são representativos de 3 experimentos independentes.Controle isotípico FITC [MIF=4,2]; Controle isotípico PE [MIF=6,1]. ${ }^{* * *} p<0,001$ grupo não-imunizado comparado com Hep-A:SBA-15 e/ou Hep-A; \# $p<0,01$ grupo Hep-A comparado com Hep-A:SBA-15; \# $p<0,05$ grupo Hep-A comparado com Hep-A:SBA-15; $\cdots p<0,001$ Hep-A:SBA-15 comparado com Hep-A [Two-way ANOVA - pós-teste de Bonferroni].

\subsection{Potencial de adsorção da sílica SBA-15}


Vale ressaltar que devido à indisponibilidade da vacina contra Hepatite $\mathrm{A}$ e, assumindo a ação geral adjuvante da SBA-15, seguiram-se estudos empregando a HGG como imunógeno.

Como o efeito adjuvante da SBA-15 parece estar associado com a taxa de encapsulação e/ou adsorção do antígeno, realizou-se experimento in vitro para verificar o potencial de adsorção da HGG, uma proteína de cerca de 150 kDa, em SBA-15. Conforme Tabela 1, aproximadamente 52,8\% do antígeno foi adsorvido pela sílica na proporção 1:5 de HGG:SBA-15; já, na proporção $1: 10,62,5 \%$ e, na proporção $1: 25,90,7 \%$ da proteína estava adsorvida; assim, quanto maior a proporção de SBA-15, maior a porcentagem da proteína adsorvida.

Tabela 1 - Porcentagem de HGG adsorvida em diferentes proporções de SBA-15. Proporção HGG:SBA-15: 1:5; 1:10; 1:25.

\begin{tabular}{ccc}
\hline $\begin{array}{c}\text { Proporção } \\
\text { HGG:SBA-15 }\end{array}$ & $\begin{array}{c}\text { Porcentagem } \\
\text { HGG livre }\end{array}$ & $\begin{array}{c}\text { Porcentagem } \\
\text { HGG adsorvida }\end{array}$ \\
\hline 1:5 & $47,2 \%$ & $52,8 \%$ \\
1:10 & $37,5 \%$ & $62,5 \%$ \\
1:25 & $9,3 \%$ & $90,7 \%$ \\
\hline
\end{tabular}

\subsection{Imunização com gamaglobulina humana [HGG]}

Camundongos $L_{\text {III }}$ [n=3 animais/grupo], fêmeas, com 6 a 8 semanas de idade foram imunizados pela via intraperitoneal com $10 \mu \mathrm{g} / \mathrm{animal}$ de HGG adsorvida em $250 \mu \mathrm{g} / \mathrm{mL}$ de SBA-15 [v/v]; ou em $250 \mu \mathrm{g} / \mathrm{mL}$ de $\mathrm{Al}(\mathrm{OH})_{3}[\mathrm{v} / \mathrm{v}]$. Segunda imunização com HGG:SBA-15 fez-se pela via intraperitoneal 60 dias após primeira imunização. Os animais foram sangrados nos $20^{\circ}$ e $50^{\circ}$ dias da resposta primária e no $15^{\circ}$ dia da secundária.

Como verificado na Figura 11, não houve nenhuma diferença na produção de anticorpos primários e secundários após imunização de HGG:SBA-15 e HGG:Al(OH) 3 . Nos dois grupos, observa-se aumento de 
aproximadamente 64 vezes nos títulos de anticorpo anti-HGG após segunda imunização comparativamente aos pré-existentes no $50^{\circ}$ dia da resposta primária.

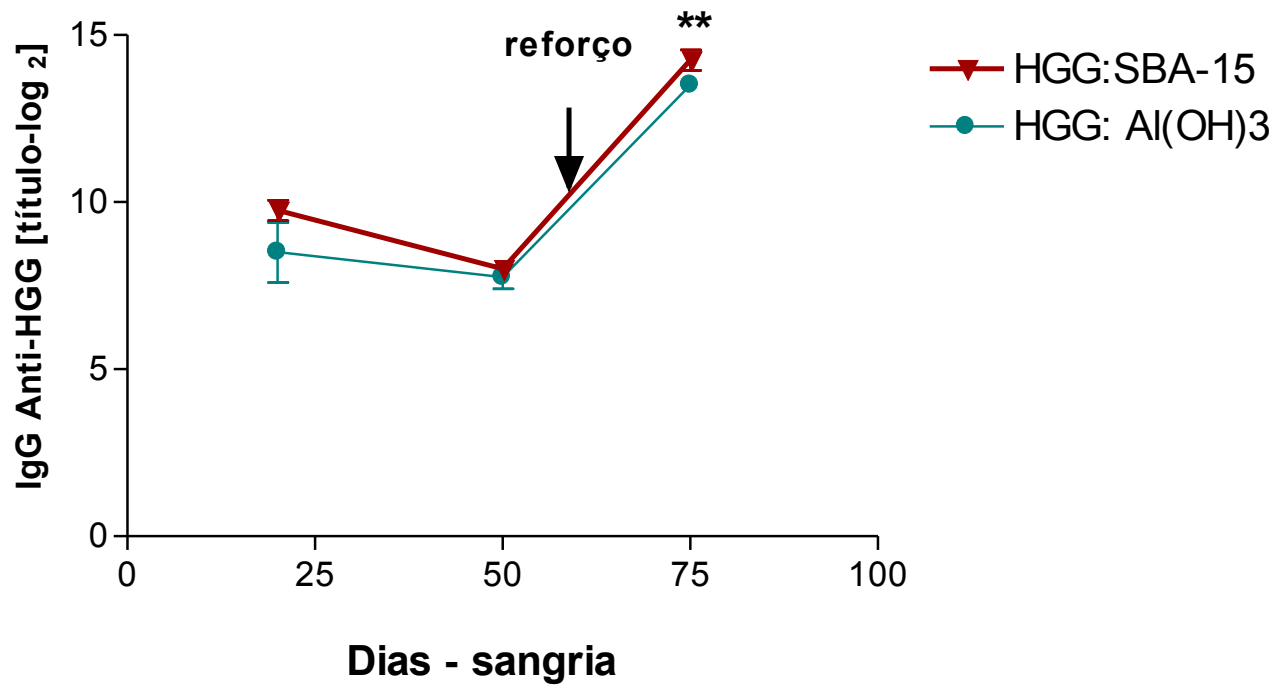

Figura 11 - Comparação dos títulos de IgG produzidos por camundongos $L_{\text {III }}$ [n=3/grupo] imunizados pela via intraperitoneal com $10 \mu \mathrm{g} /$ animal de HGG em $250 \mu \mathrm{g} / \mathrm{animal}$ de SBA-15 [v/v]; ou em $250 \mu \mathrm{g} / \mathrm{animal}$ de $\mathrm{Al}(\mathrm{OH})_{3}[\mathrm{v} / \mathrm{v}]$. Anticorpos anti-HGG foram dosados pelo método de ELISA nos $20^{\circ}, 50^{\circ}$ e $75^{\circ}$ dias após imunização. [Títulos de anticorpos obtidos no $50^{\circ}$ dia após imunização foram utilizados como referência para análises do teste $t$ de Student: $\left.{ }^{* *} p<0,01\right]$.

\subsection{Influência da SBA-15 na produção de isótipos de IgG}

Sabendo-se que a finalidade do adjuvante é potencializar, sem interferir na polarização da resposta imune específica, verificou-se a influência da SBA-15 na produção dos isótipos de lgG, IgG1 e IgG2a.

Camundongos $L_{\text {III }}[n=3 /$ grupo] imunizados pela via intraperitoneal com HGG:SBA-15 produziram no $20^{\circ}$ dia da resposta primária [RP] e no $12^{\circ}$ dia da resposta secundária [RS] ambos isótipos de lgG. Também não se verificou diferença na produção de lgG1 e IgG2a anti-HGG nos camundongos imunizados com $\mathrm{HGG}: \mathrm{Al}(\mathrm{OH})_{3}$; entretanto, observa-se, nesses animais, uma tendência a maior produção de lgG1 relativamente à lgG2a durante a resposta primária e secundária (Figura 12). 


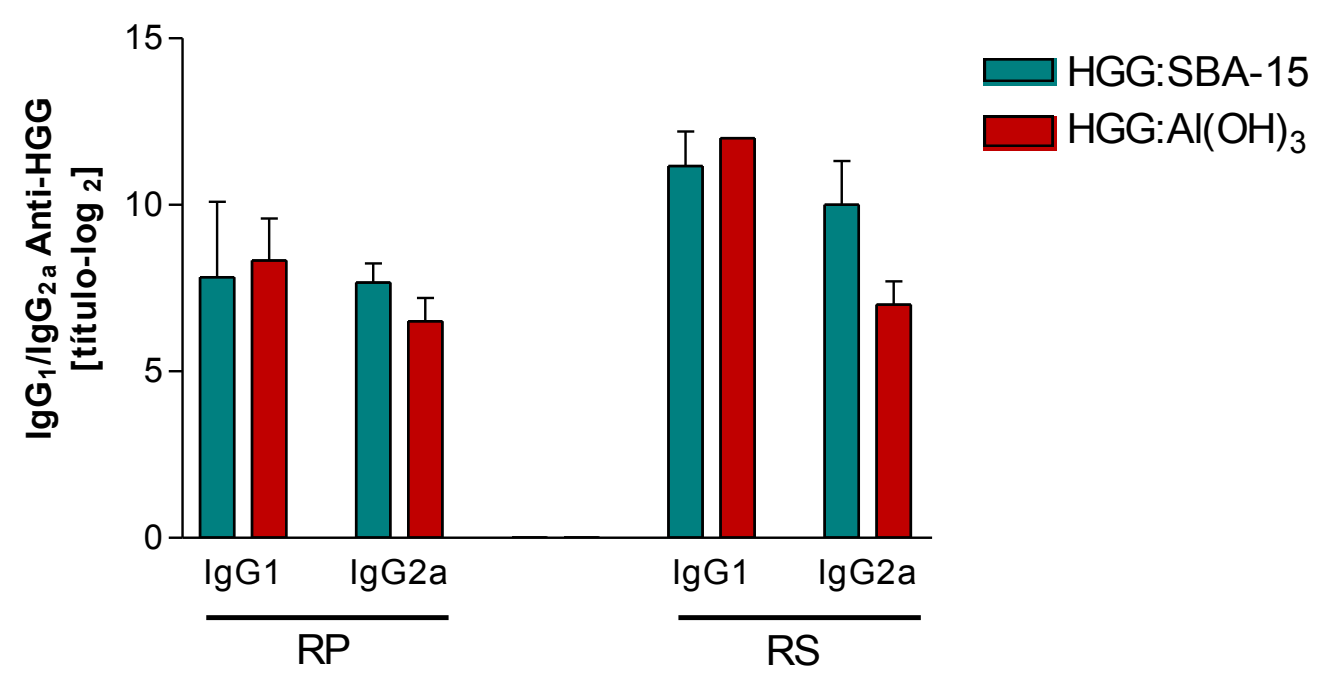

Figura 12 - Título \pm SD de lgG1 e lgG2a anti-HGG produzidos por camundongos $L_{\text {III }}$ [n= 3/grupo] imunizados pela via intraperitoneal com $10 \mu \mathrm{g}$ HGG em $250 \mu \mathrm{g} \mathrm{SBA}-15$ ou em $250 \mu \mathrm{g} \mathrm{Al}(\mathrm{OH})_{3}$. Anticorpos detectados por ELISA no $20^{\circ}$ dia da resposta primária $[R P]$ e no $12^{\circ}$ dia da resposta secundária [RS]. SD - desvio padrão.

\subsection{Análise da produção de citocinas}

Devido à importância da produção de citocinas na geração, direcionamento e manutenção da resposta imune adaptativa foram avaliados os níveis de IL-2, IL-4, IL-5, IL-10, IL-13 e IFN- $\gamma$ nos sobrenadantes das células dos linfonodos drenantes de camundongos imunizados com HGG:PBS; HGG:SBA-15; $\mathrm{HGG:AI(OH})_{3}$. Para tanto, as suspensões celulares obtidas foram reestimuladas in vitro com HGG [250 $\mu \mathrm{g} / \mathrm{mL}$ ]; meio RPMI ou ConA [4 $\mu \mathrm{g} / \mathrm{mL}]$ por 48 horas.

Os níveis de IL-4, IL-5 e IL-13 estiveram abaixo do limite de detecção dos ensaios, sendo assim, não foi possível mensurar a produção dessas citocinas nos sobrenadantes de células dos grupos experimentais.

A produção de IL-2 na presença de meio e HGG foi semelhante nas culturas de células dos diferentes grupos. Observa-se após estímulo inespecífico com ConA maior produção de IL-2 na cultura de células do grupo HGG:Al $(\mathrm{OH})_{3}$ relativamente aos grupos HGG e/ou HGG:SBA-15; no entanto, 
houve maior secreção dessa citocina no grupo HGG:SBA-15 comparativamente ao grupo HGG (Figura 13).

IL-2

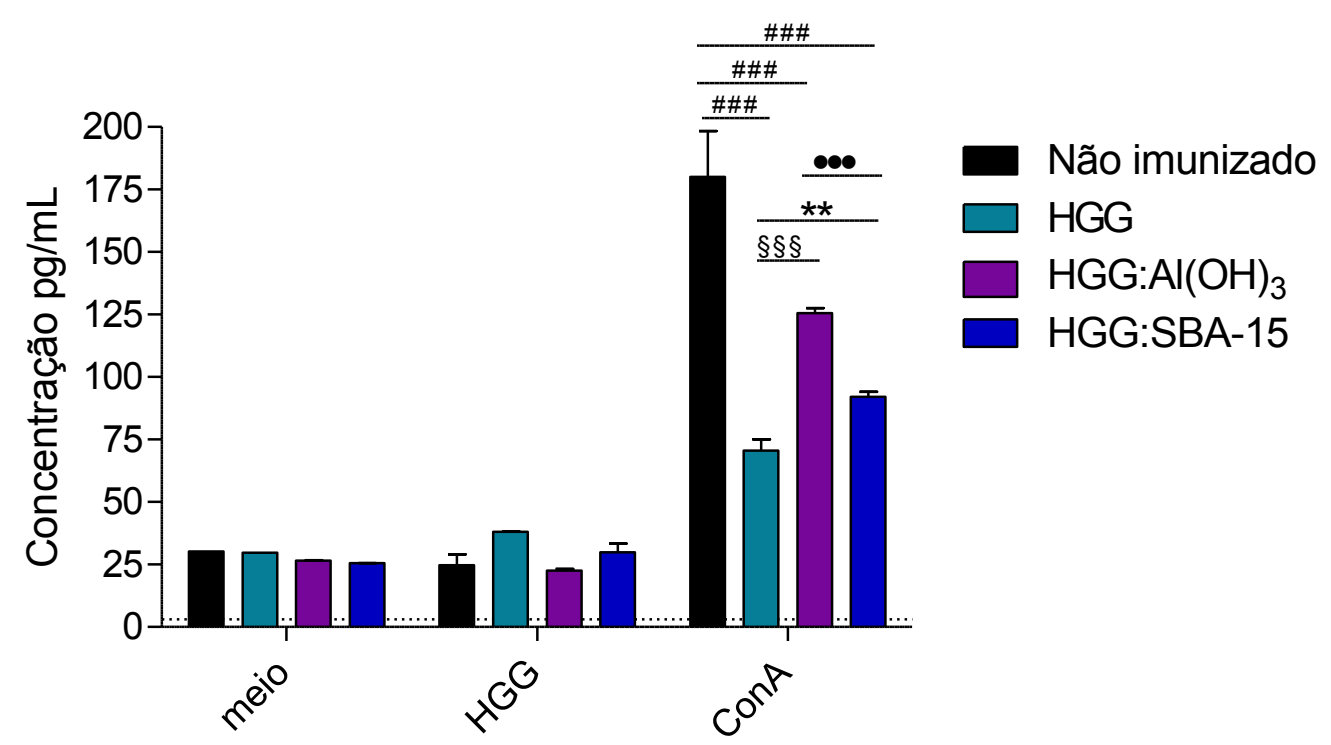

Figura 13 - Produção de IL-2 nas culturas celulares de linfonodos de camundongos BALB/c [n=5/grupo] imunizados ou não com HGG; HGG:SBA-15; HGG:Al(OH) $)_{3}$. As células foram re-estimuladas in vitro com HGG [250 $\mu \mathrm{g} / \mathrm{mL}$ ]; meio RPMI ou ConA [ $4 \mu \mathrm{g} / \mathrm{mL}$ ] por 48 horas. A produção de IL-2 foi determinada por ELISA nos sobrenadantes das culturas e a concentração calculada a partir da curva padrão estabelecida com a citocina recombinante. Os resultados representam a média da concentração de IL-2 obtida das amostras em duplicata \pm desvio-padrão. Resultados representativos de 2 experimentos independentes. A linha tracejada representa o limite de detecção do ensaio utilizado [3,12 pg/mL]. Para análise da variância utilizou-se Two-way ANOVA pós-teste de Bonferroni: \#\# $p<0,001$-grupo não imunizado comparado aos demais; ${ }^{\S \S} p<0,001$ - grupo HGG comparado ao HGG:Al(OH $)_{3}$; $p<0,001$-grupo HGG:SBA-15 comparado ao $\mathrm{HGG}: \mathrm{Al}(\mathrm{OH})_{3}$; ${ }^{* *} p<0,01$ grupo HGG comparado ao HGG:SBA-15.

A Figura 14 ilustra secreção semelhante de IFN- $\gamma$ nas culturas de células de camundongos imunizados com HGG:SBA-15 ou HGG:Al(OH) 3 quando estimuladas in vitro com HGG. Em resposta à estimulação mitogênica observase que todas as culturas de células secretaram IFN- $\gamma$, no entanto, a maior produção dessa citocina foi verificada na cultura de células de camundongos imunizados com HGG:SBA-15. 


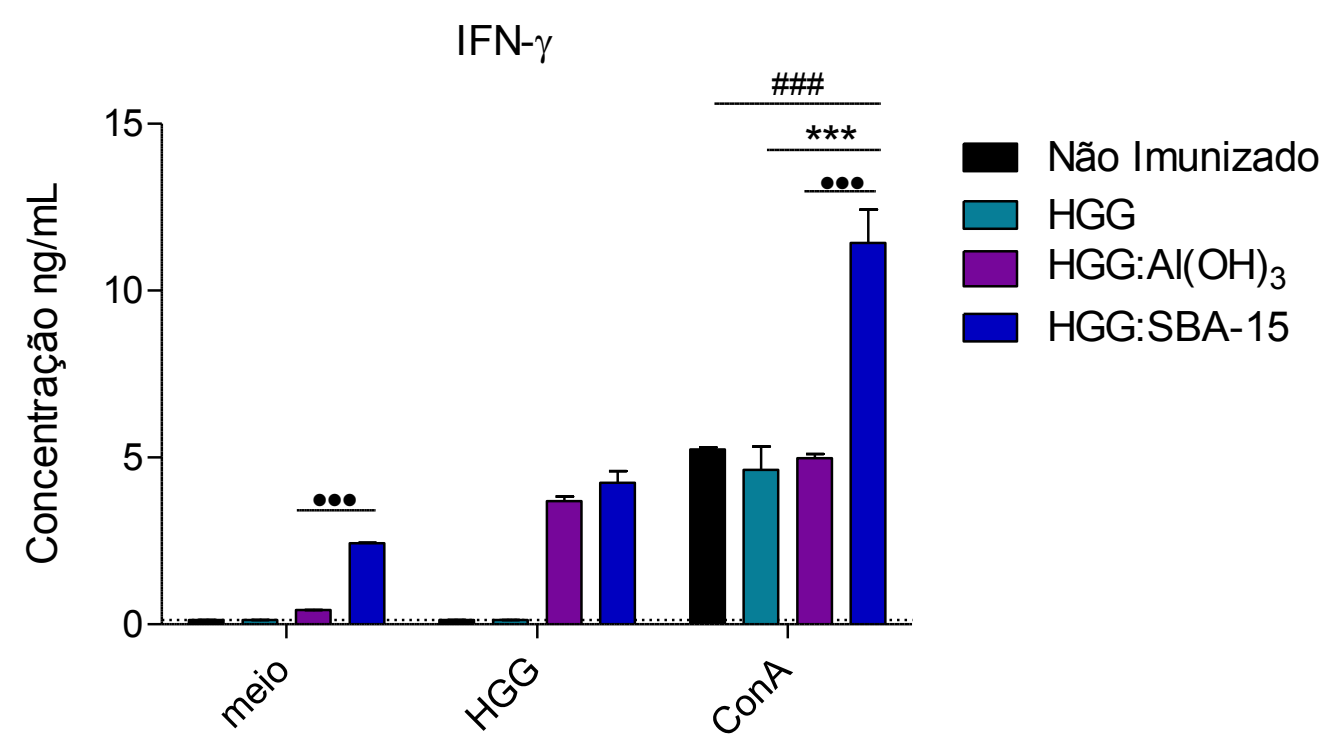

Figura 14 - Produção de IFN- $\gamma$ nas culturas celulares de linfonodos de camundongos BALB/c [n=5/grupo] imunizados ou não com HGG; HGG:SBA-15; HGG:Al(OH) 3 . As células foram re-estimuladas in vitro com HGG [250 $\mu \mathrm{g} / \mathrm{mL}$ ]; meio RPMl ou ConA [4 $\mu \mathrm{g} / \mathrm{mL}$ ] por 48 horas. A produção de IFN$\gamma$ foi determinada por ELISA nos sobrenadantes das culturas e a concentração calculada a partir da curva padrão estabelecida com a citocina recombinante. Os resultados representam a média da concentração de IFN- $\gamma$ obtida das amostras em duplicata \pm desviopadrão. Resultados representativos de 2 experimentos independentes. A linha tracejada representa o limite de detecção do ensaio utilizado $[0,125 \mathrm{ng} / \mathrm{mL}]$. Para análise da variância utilizou-se Two-way ANOVA pós-teste de Bonferroni: ${ }^{\#} p<0,001$-grupo não imunizado comparado ao HGG:SBA-15; ${ }^{* * *} p<0,001$ - grupo HGG comparado ao HGG:SBA-15; ... $p<0,001$-grupo HGG:SBA-15 comparado ao HGG:Al(OH $)_{3}$.

$\mathrm{Na}$ cultura de células dos camundongos imunizados com HGG; HGG:SBA-15; HGG:Al(OH $)_{3}$ há secreção semelhante de IL-10 após estímulo mitogênico, contudo, após estimulação antígeno-específica [HGG], verifica-se maior produção desta citocina nos sobrenadantes de células de camundongos imunizados com HGG e/ou com HGG:SBA-15 relativamente aos imunizados com HGG:Al(OH) $)_{3}$ e/ou não-imunizados (Figura 15). 


\section{IL-10}

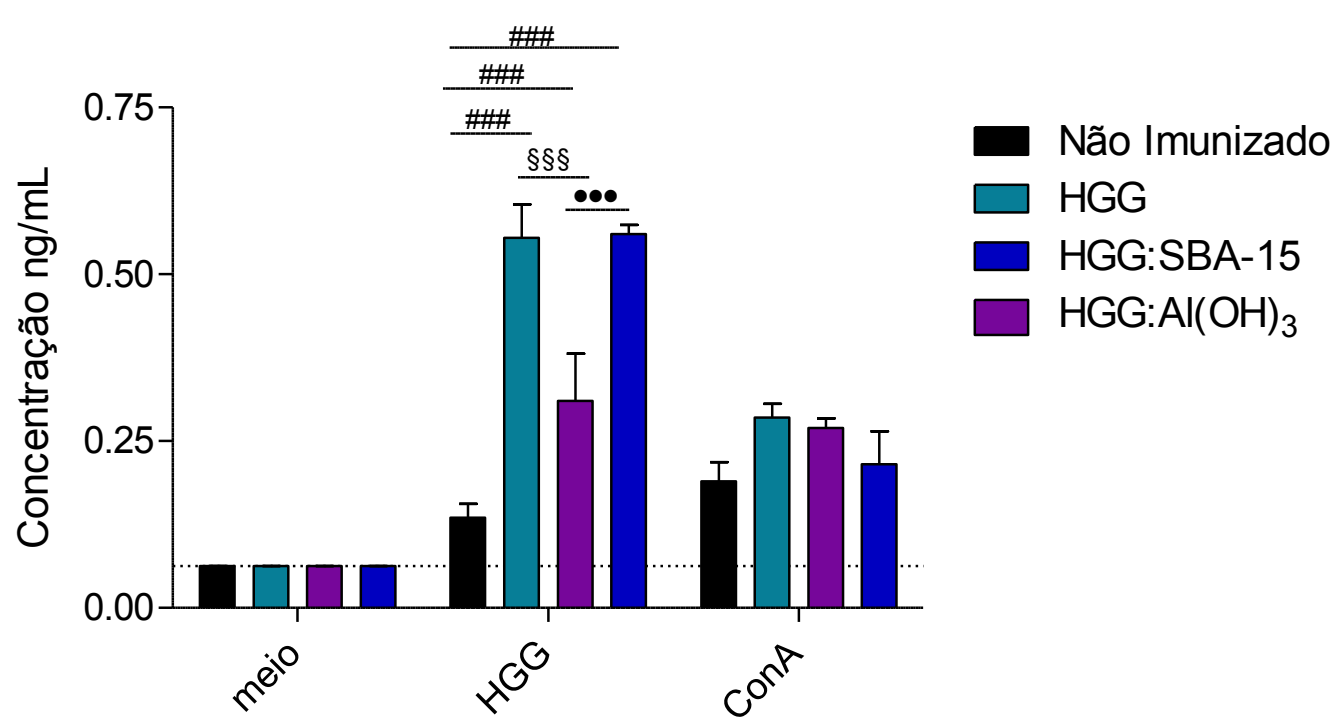

Figura 15 - Produção de IL-10 nas culturas celulares de linfonodos de camundongos BALB/c [n=5/grupo] imunizados ou não com HGG; HGG:SBA-15; HGG:Al(OH $)_{3}$. As células foram re-estimuladas in vitro com HGG [250 $\mu \mathrm{g} / \mathrm{mL}$ ]; meio RPMI ou com ConA [4 $\mu \mathrm{g} / \mathrm{mL}$ ] por 48 horas. A produção de IL-10 foi avaliada por ELISA nos sobrenadantes das culturas celulares e a concentração determinada a partir da curva padrão estabelecida com a citocina recombinante. Os resultados estão expressos em média da concentração de IL-10 nas amostras em duplicata \pm desvio padrão. A linha tracejada representa o limite de detecção do ensaio utilizado $[0,0625 \mathrm{ng} / \mathrm{mL}]$. Para análise da variância utilizou-se Two-way ANOVA - pós-teste de Bonferroni: \#\# $p<0,001$ grupo não imunizado comparado aos demais; ${ }^{\S \S} p<0,001$ - grupo HGG comparado ao HGG: $\mathrm{Al}(\mathrm{OH})_{3}$; comparado ao $\mathrm{HGG}: \mathrm{Al}(\mathrm{OH})_{3}$.

\subsection{Análise da resposta proliferativa de células de camundongos imunizados com HGG; HGG:SBA-15; HGG:AI(OH) 3}

Seguiu-se análise do efeito da SBA-15 na resposta proliferativa de linfócitos $T$. Para isto, suspensões celulares dos linfonodos de camundongos imunizados com HGG:PBS; HGG:SBA-15; $\mathrm{HGG:Al(OH})_{3}$ foram reestimuladas in vitro com HGG [500 $\mu \mathrm{g} / \mathrm{mL}$ ]; meio RPMI ou ConA [2 $\mu \mathrm{g} / \mathrm{mL}$ ] por 48 ou 96 horas e a proliferação celular avaliada.

Como pode ser visto na Figura 16, o pico de resposta proliferativa das culturas estimuladas com ConA ocorreu nas 48 horas enquanto que, para a 
estimulação com HGG, ocorreu nas 96 horas de cultura. Além disso, maior proliferação celular foi obtida nas culturas de células de camundongos imunizados com HGG:SBA-15 após 48 ou 96 horas de estimulação com HGG em relação ao observado nas culturas dos demais grupos. Quanto à estimulação com ConA, também foi possível verificar maior resposta proliferativa nas culturas de células de camundongos imunizados com HGG:SBA-15 quando comparada à obtida nas culturas dos grupos HGG:PBS e/ou não imunizados; entretanto, houve diferença entre HGG:SBA-15 e HGG:Al $(\mathrm{OH})_{3}$ apenas após 96 horas de estimulação com ConA. 


\section{8 horas}

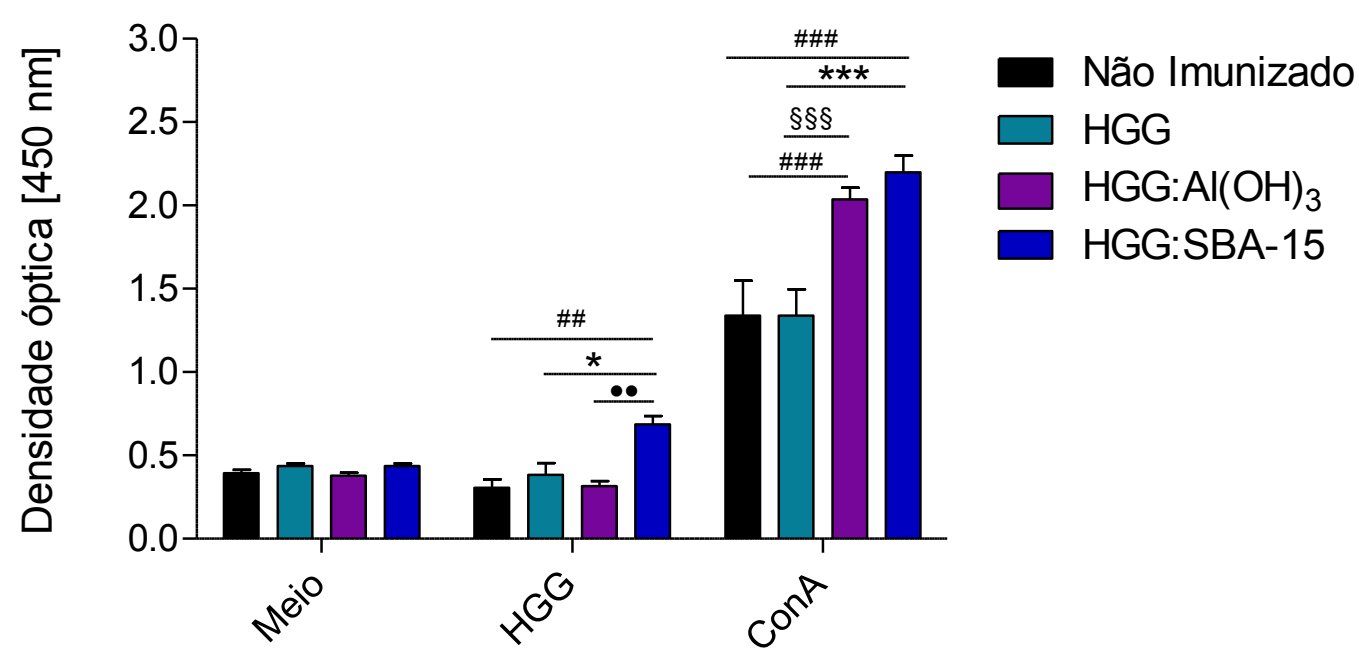

96 horas

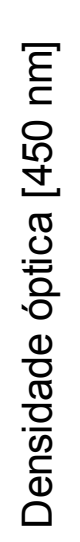

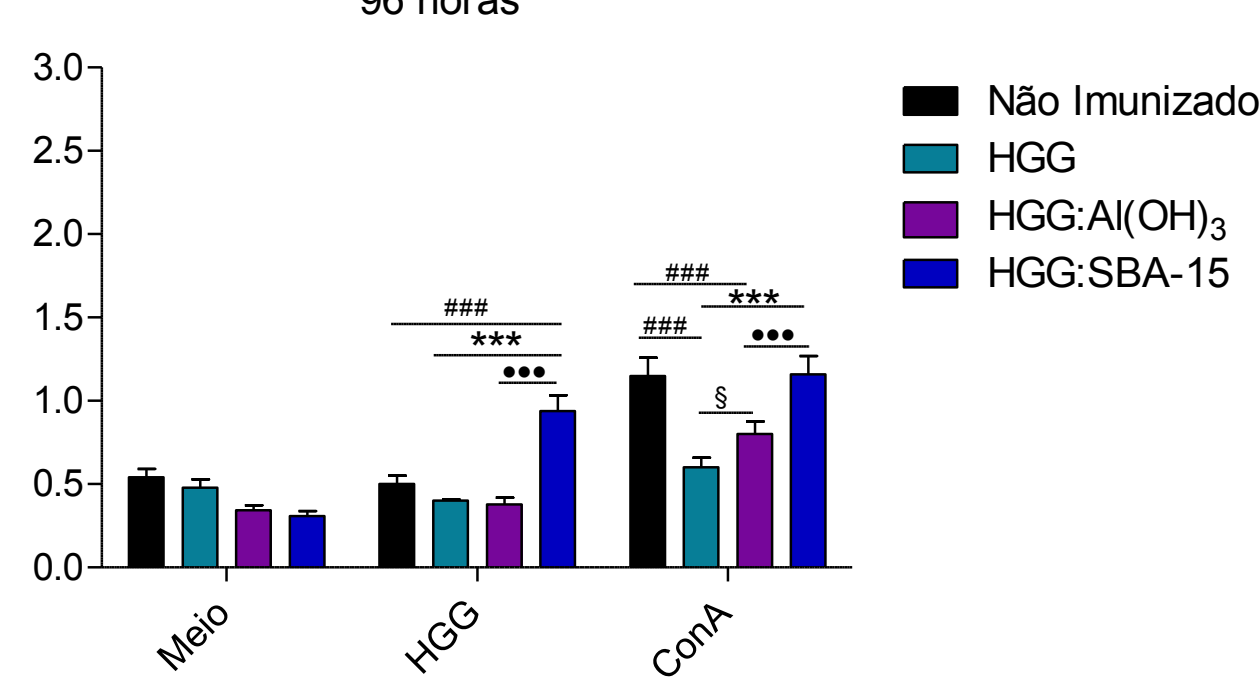

Figura 16 - Resposta proliferativa em culturas de células de linfonodos de camundongos $B A L B / c$ [n=4/grupo] imunizados ou não com HGG; HGG:SBA-15; $\mathrm{HGG}: \mathrm{Al}(\mathrm{OH})_{3}$. As células foram re-estimuladas in vitro com HGG [500 $\mu \mathrm{g} / \mathrm{mL}$ ]; meio RPMI ou ConA [2 $\mu \mathrm{g} / \mathrm{mL}$ ] por 48 ou 96 horas. A proliferação foi avaliada pelo "Kit Cell proliferation ELISA Biotrak System version 2". Os resultados estão expressos em média da densidade óptica das amostras em triplicata \pm desvio padrão. Resultados representativos de 2 experimentos independentes. Para análise da variância utilizou-se Two-way ANOVA - pós-teste de Bonferroni: \# $p<0,001$-grupo não imunizado comparado aos demais; \# $p<0,01$-grupo não imunizado comparado ao HGG:SBA-15; §§ $p<0,001$ - grupo HGG comparado ao $\mathrm{HGG:Al(OH})_{3}$; ${ }^{\S} p<0,05-$ grupo HGG comparado ao HGG:Al(OH) $)_{3}{ }^{* * *} p<0,001$ - grupo HGG comparado ao HGG:SBA-15; * $p<0,05$ - grupo HGG comparado ao HGG:SBA-15; $\cdots p<0,001$-grupo HGG:SBA-15 comparado ao HGG:Al(OH $)_{3} ; \quad \cdots \quad p$ <0,01-grupo HGG:SBA-15 comparado ao $\mathrm{HGG}: \mathrm{Al}(\mathrm{OH})_{3}$. 


\subsection{Estudo das populações celulares presentes nos linfonodos de camundongos imunizados com HGG adsorvida ou não em SBA-15 ou em $\mathrm{Al}(\mathrm{OH})_{3}$}

Considerando que a imunização dos camundongos com HGG adsorvida em SBA-15 resulta em potente resposta humoral e celular, decidiu-se estudar a participação das APCs nesse processo. Inicialmente, analisou-se as diferentes populações celulares presentes nos linfonodos inguinais e periaórticos de camundongos BALB/c [n=4/grupo] imunizados com HGG adsorvida ou não à sílica SBA-15 ou ao $\mathrm{Al}(\mathrm{OH})_{3}$. Após $\circ 3^{\circ}, 5^{\circ}$ e $7^{\circ}$ dia da imunização, as suspensões celulares de camundongos foram preparadas e marcadas com anticorpos anti-CD11b, anti-CD11c, anti-CD4, anti-CD8 ou anti-B220 de camundongo conjugados à FITC ou PE e analisada por citometria de fluxo.

Verifica-se no $3^{\circ}$ dia pós-imunização, aumento no número de células

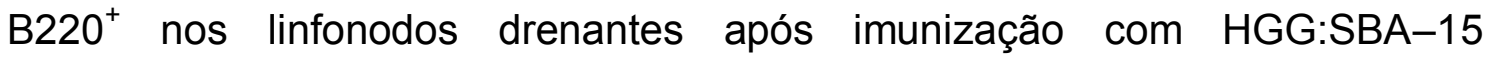
comparativamente ao grupo $\mathrm{HGG}: \mathrm{Al}(\mathrm{OH})_{3}$ e/ou HGG:PBS [ [ $\left.p<0,001\right]$; no entanto, os dois adjuvantes recrutaram maior número dessa célula em relação ao antígeno solúvel [ ${ }^{\S} p<0,001-$ HGG:SBA-15 comparada à HGG:PBS; \& $p<0,01$ HGG:Al(OH) ${ }_{3}$ comparada à HGG:PBS], sendo esse dado também observado no $7^{\circ}$ pós-imunização (Figura 17 ). Ainda, no $5^{\circ}$ dia há maior número de células $\mathrm{CD}^{+}$na suspensão celular do grupo HGG:SBA-15 relativamente ao grupo HGG [ $\left.{ }^{\S} p<0,001\right]$, além do maior número de células $\mathrm{CD}^{+}{ }^{+}$em relação aos outros grupos experimentais $\left[^{\S} p<0,001\right]$. No $7^{\circ}$ dia, observa-se maior número de células $\mathrm{CD}_{11 \mathrm{c}^{+}}$após imunização com HGG:SBA-15 comparativamente à imunização com HGG [ $\left.{ }^{\&} p<0,01\right]$ e/ou $\left.\mathrm{HGG:AI(OH}\right)_{3}$ $\left[{ }^{*} p<0,05\right]$; entretanto, na suspensão celular do grupo $\mathrm{HGG}: \mathrm{Al}(\mathrm{OH})_{3}$ há mais células CD4 ${ }^{+}$em relação ao grupo HGG:SBA-15 [ $\left.{ }^{\&} p<0,01\right]$ (Figura 17) . 


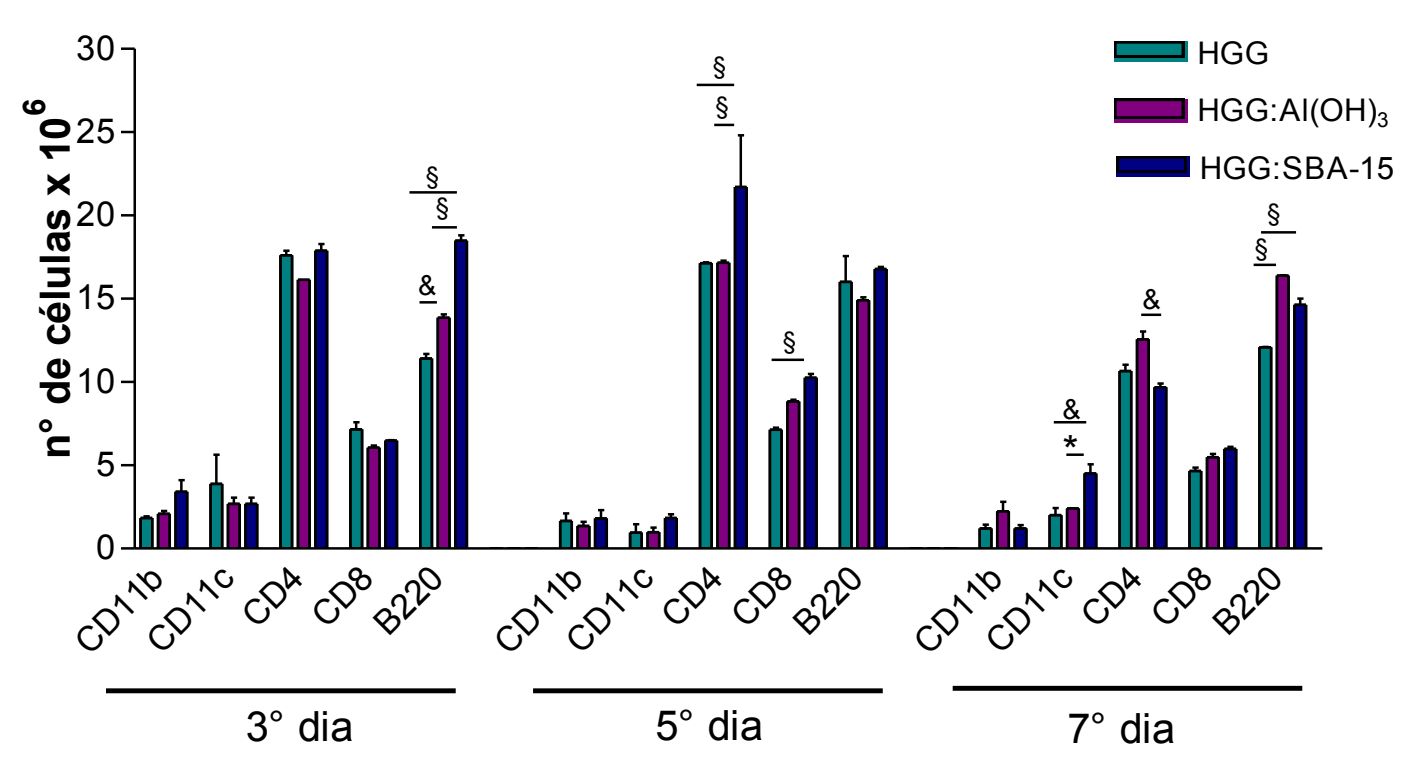

Figura 17 - Número de células $\mathrm{CD} 11 \mathrm{~b}^{+}, \mathrm{CD} 11 \mathrm{c}^{+}, \mathrm{CD} 4^{+}, \mathrm{CD} 8^{+}, \mathrm{B220^{+ }}$ presentes nas suspensões celulares de linfonodos inguinais e periaórticos obtidos após $03^{\circ}, 5^{\circ}$ e $7^{\circ}$ dia da imunização de camundongos BALB/c [n=4/grupo] pela via subcutânea [base da cauda] com HGG:PBS ["]; HGG em SBA-15 ["]; HGG em $\mathrm{Al}(\mathrm{OH})_{3}[\square]$. Os resultados são expressos em média \pm desvio padrão do número absoluto de células marcadas das amostras em duplicata. Os resultados são representativos de 2 experimentos independentes. Para análise da variância utilizou-se Two-way ANOVA pós-teste de Bonferroni $-{ }^{\S} p<0,001$; ${ }^{\circledR} p<0,01$; * $p<0,05$.

4.10.1 Expressão de moléculas de MHC-II, CD40, CD80, CD86 em células de camundongos imunizados com HGG adsorvida em SBA-15 ou em $\mathrm{Al}(\mathrm{OH})_{3}$

Para análise do efeito da SBA-15 nas APCs, analisou-se a expressão de MHC-II, CD40, CD80 e CD86 nas suspensões celulares de linfonodos drenantes de camundongos imunizados com HGG:PBS; $\mathrm{HGG:AI}(\mathrm{OH})_{3}$ ou HGG:SBA-15. Após 5 dias da imunização, as células foram preparadas e incubadas com anticorpos anti-MHC-II, CD40, CD80 e CD86 conjugados em FITC ou PE e analisadas por citometria de fluxo.

Conforme Figura 18, na suspensão celular de camundongos imunizados com HGG adsorvida em SBA-15 há expressão elevada de CD40 quando comparada à de camundongos imunizados com $\mathrm{HGG}: \mathrm{Al}(\mathrm{OH})_{3}\left[{ }^{*} p<0,01\right]$ e/ou 
HGG:PBS [** $p<0,01]$ e, de CD80 relativamente à do grupo HGG:Al(OH $)_{3}$ [” $p<0,001]$. Ainda, observa-se nas células obtidas do grupo HGG:PBS maior expressão de CD80 em relação às do grupo HGG:Al(OH) 3 [ $\left.{ }^{\# \#} p<0,001\right]$ e/ou HGG:SBA-15 [* $p<0,05]$ e, de MHC-II comparativamente às do grupo HGG:SBA-15 [ $\left.{ }^{* *} p<0,01\right]$ (Figura 18). 


\section{HGG:PBS}
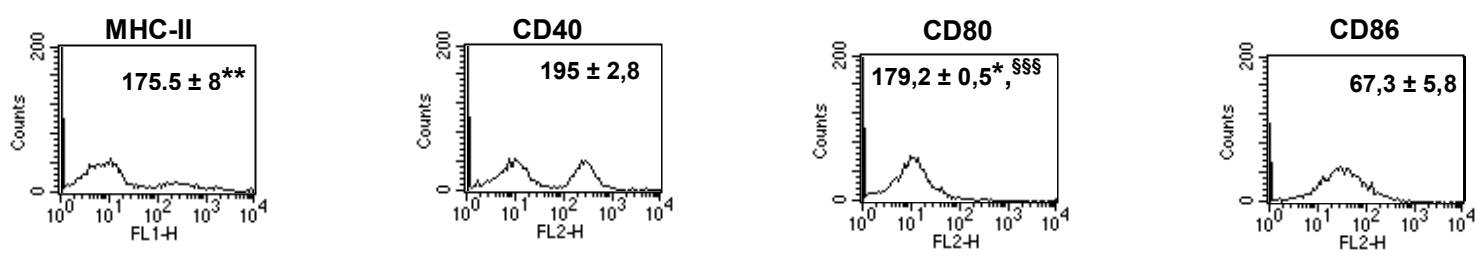

\section{HGG:Al(OH) 3}
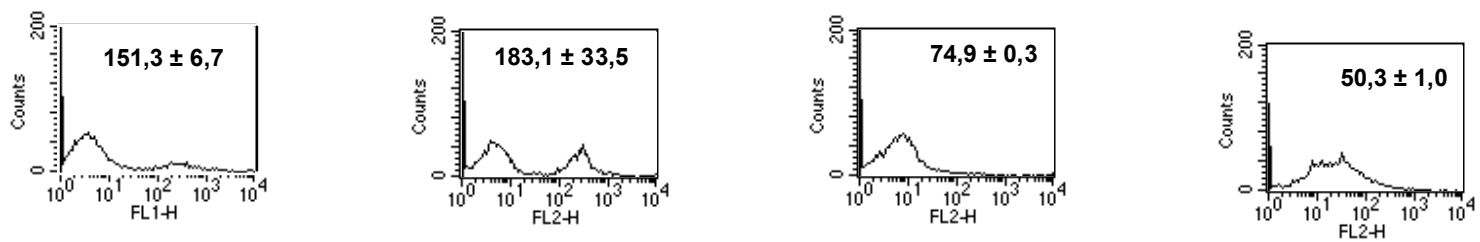

HGG:SBA-15
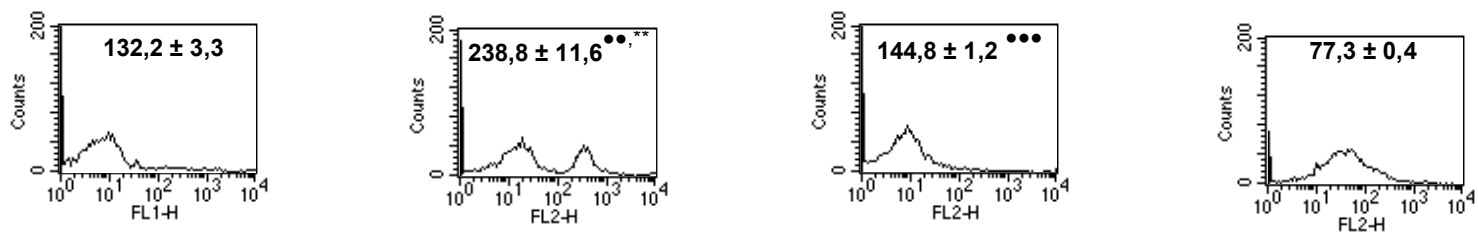

Figura 18 - Expressão das moléculas de MHC-II, CD40, CD80 e CD86 nas células de linfonodos drenantes após 5 dias de imunização dos camundongos com HGG:PBS; $\mathrm{HGG}$ em $\mathrm{Al}(\mathrm{OH})_{3}$ ou HGG em SBA-15. Os resultados foram expressos em média de intensidade de fluorescência [MIF] \pm desvio padrão das amostras em duplicata e são representativos de 2 experimentos independentes. Controle isotípico FITC [MIF=8,9]; Controle isotípico PE [MIF=5,3]. ${ }^{* *} p<0,01$ - grupo HGG:PBS comparado com HGG:SBA-15; * $p<0,05$ - grupo HGG:PBS comparado com HGG:SBA-15; $\S \S \S<0,001$ - grupo HGG:PBS comparado com HGG:AI(OH) $)_{3} ;{ }^{\prime} p<0,01$ grupo HGG:SBA-15 comparado com HGG:AI(OH) $)_{3} ;{ }^{\cdots} p<0,001$ - grupo HGG:SBA-15 comparado com HGG:Al(OH $)_{3}$ - Two-way ANOVA - pósteste de Bonferroni. 


\subsubsection{Expressão de moléculas coestimuladoras nas APCs de camundongos imunizados com HGG adsorvida ou não em SBA-15 ou em $\mathrm{Al}(\mathrm{OH})_{3}$}

Diante do aumento da expressão de moléculas coestimuladoras CD40 e CD80 nas suspensões celulares de linfonodos drenantes de camundongos imunizados com HGG:SBA-15 (Figura 18), realizaram-se experimentos para avaliar qual APC apresentou maior expressão dessas moléculas. Para isto, repetiu-se o protocolo de imunização de camundongos com HGG:PBS; HGG:Al $(\mathrm{OH})_{3}$ ou HGG:SBA-15 e, 5 dias após a imunização, as suspensões celulares foram submetidas à dupla marcação [anti-CD11c-FITC/anti-CD40PE, anti-CD80-PE ou anti-CD86-PE; anti-CD11b-FITC/anti-CD40-PE, antiCD80-PE ou anti-CD86-PE; anti-B220-FITC/anti-CD40-PE, anti-CD80-PE ou anti-CD86-PE. Como controle, as células foram incubadas com anticorpos antiCD4-FITC/anti-CD8-PE ou com os controles isotípicos conjugados à FITC ou PE e analisadas quanto à dupla marcação em citômetro de fluxo.

Comparativamente aos animais não imunizados, a imunização com HGG:SBA-15 aumentou a expressão de CD40, CD80 e CD86 nas células $\mathrm{CD}_{11 \mathrm{c}^{+}}, \mathrm{CD}_{11 \mathrm{~b}^{+} \text {e B220 }}$; já, a imunização com $\mathrm{HGG:Al}(\mathrm{OH})_{3}$ modulou a expressão de CD40 e CD86 nas células CD11c ${ }^{+}$; de CD80 e CD86 nas células

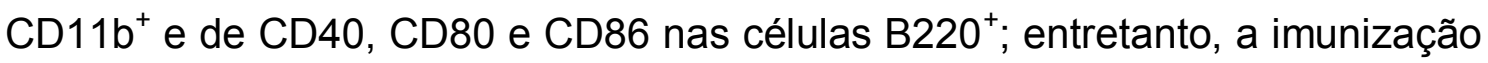
com a proteína solúvel foi capaz de modular a expressão de moléculas coestimuladoras apenas nas células $C^{2} 11 b^{+}[C D 86]$ e $B 220^{+}[C D 40$ e CD86] (Figura 19).

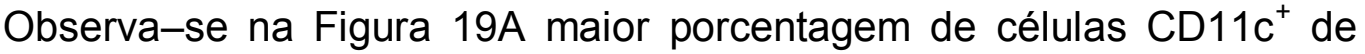
camundongos imunizados com HGG:SBA-15 que expressam CD40

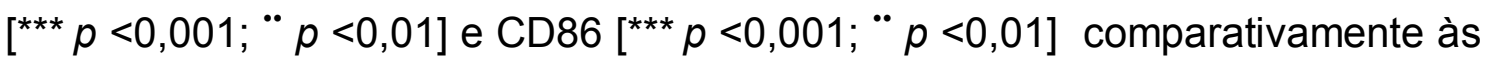
de camundongos imunizados com HGG:PBS e/ou HGG:Al(OH) respectivamente; entretanto, quanto às células $\mathrm{CD} 11 \mathrm{C}^{+} \mathrm{CD} 80^{+}$há diferença significativa somente em relação à HGG:PBS [ $\left.{ }^{* *} p<0,01\right]$. Ainda, verifica-se maior porcentagem de células $\mathrm{CD} 11 \mathrm{c}^{+} \mathrm{CD} 40^{+}$no grupo $\mathrm{HGG}: \mathrm{Al}(\mathrm{OH})_{3}$ em relação ao grupo HGG:PBS $\left[{ }^{\S} p<0,05\right]$. 
Na suspensão obtida de camundongos imunizados com HGG:SBA-15, observa-se maior porcentagem de células CD11 $\mathrm{b}^{+} \mathrm{CD} 40^{+}$ $\left[{ }^{* * *} p<0,001 ; \cdots p<0,001\right]$ ou $\left.\mathrm{CD}^{\prime} 11 \mathrm{~b}^{+} \mathrm{CD}^{*} 6^{+}{ }^{*} p<0,05 ;{ }^{*} p<0,01\right]$ quando comparada às obtidas nos grupos HGG:PBS e/ou HGG:Al(OH) respectivamente; no entanto, para células $\mathrm{CD} 11 \mathrm{~b}^{+} \mathrm{CD} 80^{+}$a diferença foi significativa em relação HGG:PBS [ $\left.{ }^{* *} p<0,01\right]$ (Figura 19B).

Conforme Figura 19C nota-se nos animais imunizados com HGG:SBA15 maior porcentagem de células $\mathrm{B}^{2} 2 \mathrm{O}^{+} \mathrm{CD} 86^{+}$relativamente aos imunizados com HGG:PBS [ $\left.{ }^{* *} p<0,001\right]$ e HGG:Al $(\mathrm{OH})_{3}\left[{ }^{\cdots *} p<0,001\right]$; e de B220 ${ }^{+} \mathrm{CD} 40^{+}$ quando comparada aos imunizados com $\mathrm{HGG}: \mathrm{Al}(\mathrm{OH})_{3}\left[{ }^{*} p<0,01\right]$. A porcentagem de células $\mathrm{B}^{2} 20^{+} \mathrm{CD}{ }^{+}$foi semelhante entre os diferentes grupos. No grupo HGG:PBS observa-se maior porcentagem de $B 220^{+} \mathrm{CD} 40^{+}$ em relação ao grupo $\mathrm{HGG}: \mathrm{Al}(\mathrm{OH})_{3}\left[{ }^{\S \S \S} p<0,001\right]$. 
A
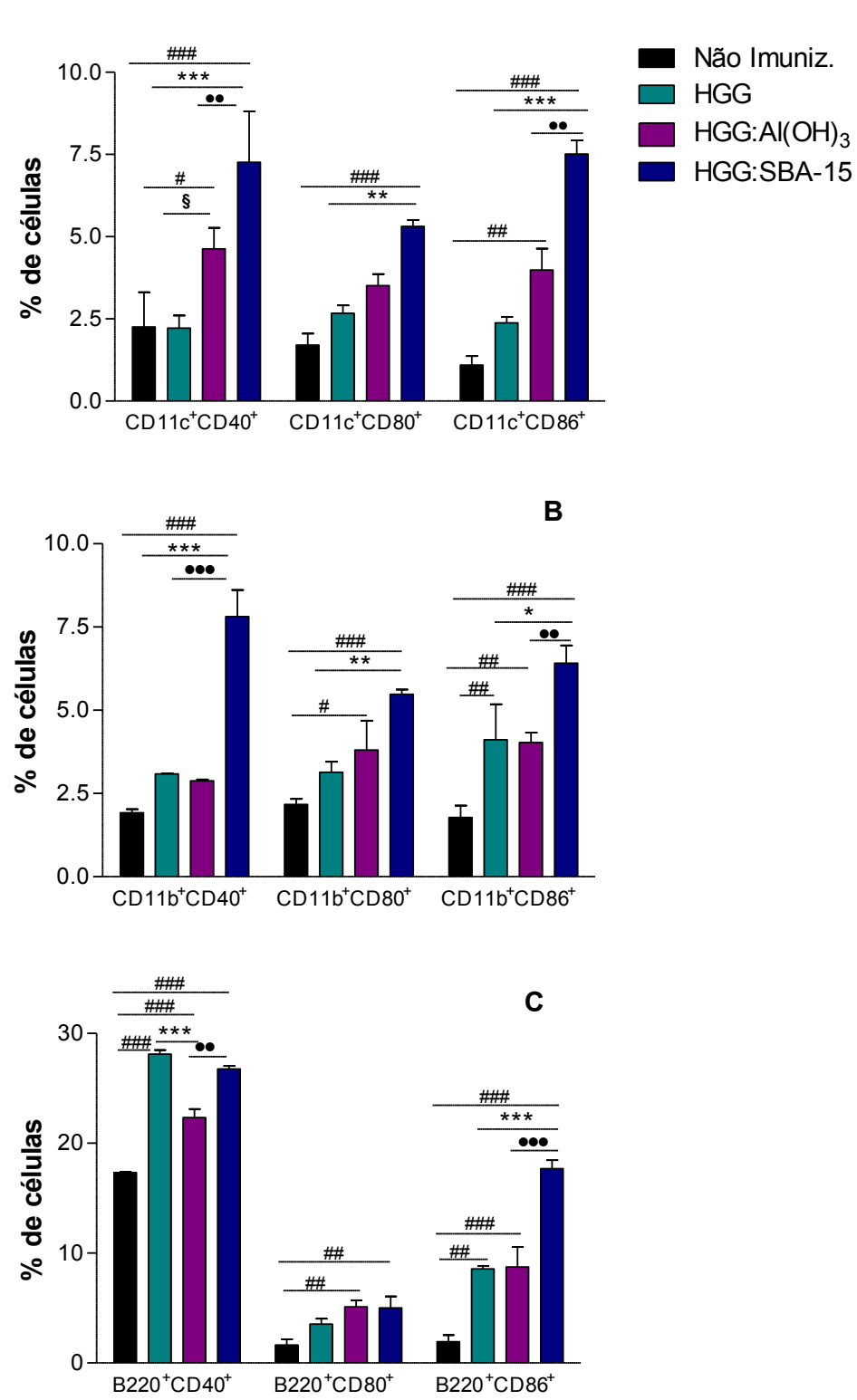

Figura 19 - Porcentagem [\%] de células CD11c ${ }^{+}[A], C D 11 b^{+}[B]$ e $B 220^{+}[C]$ que expressam CD40, CD80 e CD86. Suspensões celulares de linfonodos drenantes após $5^{\circ}$ dia da imunização de camundongos BALB/c [n=4/grupo] pela via subcutânea [base da cauda] com HGG:PBS [ ]; HGG em SBA-15 [ $\square$ ]; HGG em $\mathrm{Al}(\mathrm{OH})_{3}$ [曰]. Os resultados são expressos em média \pm desvio padrão da porcentagem de células duplo-marcadas das amostras em duplicata. Os resultados são representativos de 3 experimentos independentes. Para análise da variância utilizou-se Twoway ANOVA - pós-teste de Bonferroni: \# $p<0,001$-grupo não imunizado comparado aos demais; \# $p<0,01$-grupo não imunizado comparado aos demais; ${ }^{\#} p<0,05$ - grupo não imunizado comparado ao HGG:Al(OH) $)_{3}$; ${ }^{* *} p<0,001$ - grupo HGG comparado ao HGG:SBA-15; ** $p<0,01$ - grupo HGG comparado ao HGG:SBA-15; * $p<0,05$ - grupo HGG comparado ao HGG:SBA-15; $\cdots p<0,001$-grupo HGG:SBA-15 comparado ao HGG:Al(OH) $)_{3} ; "$ " $p<0,01$-grupo HGG:SBA-15 comparado ao $\mathrm{HGG}: \mathrm{Al}(\mathrm{OH})_{3} ;{ }^{\S} p<0,05$ - grupo HGG comparado ao $\mathrm{HGG}: \mathrm{Al}(\mathrm{OH})_{3}$. 
4.10.3 Expressão de moléculas MHC-ll e coestimuladoras em células CD11c $^{+}$purificadas de camundongos imunizados com HGG adsorvida em SBA-15 ou em $\mathrm{Al}(\mathrm{OH})_{3}$

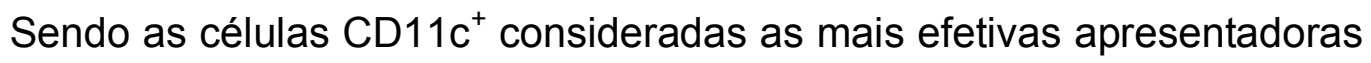
de antígenos e, devido a sua baixa frequência nos linfonodos drenantes quando comparadas às outras populações celulares, avaliou-se a expressão das moléculas MHC-II, CD40, CD80 e CD86 em células CD11c ${ }^{+}$purificadas. Repetiu-se o protocolo de imunização com HGG:SBA-15 ou HGG:Al(OH $)_{3}$ em camundongos BALB/c. No $5^{\circ}$ dia pós-imunização, prepararam-se suspensões celulares a partir dos linfonodos drenantes e incubou-se com anticorpo antiCD11c ligado à microesferas magnéticas e as células $\mathrm{CD}_{11} \mathrm{c}^{+}$foram purificadas por seleção positiva em sistema de colunas MidiMacs, conforme descrito na seção 3.9. As células $\mathrm{CD} 11 \mathrm{c}^{+}$purificadas foram incubadas com anticorpos anti-MHC-II, anti-CD40, anti-CD80 ou anti-CD86 conjugados à FITC ou PE e analisadas por citometria de fluxo. Vale ressaltar que a quantidade de células $\mathrm{CD}_{11 \mathrm{c}^{+}}$purificadas de camundongos não imunizados foi insuficiente para realizar as marcações.

Pode-se verificar na Figura 20 expressão aumentada de MHC-II, CD40, CD80 e CD86 nas células CD11 $^{+}$purificadas de camundongos imunizados com HGG:SBA-15 relativamente às de camundongos imunizados com $\mathrm{HGG}: \mathrm{Al}(\mathrm{OH})_{3}$. 


\section{HGG:Al(OH) 3}
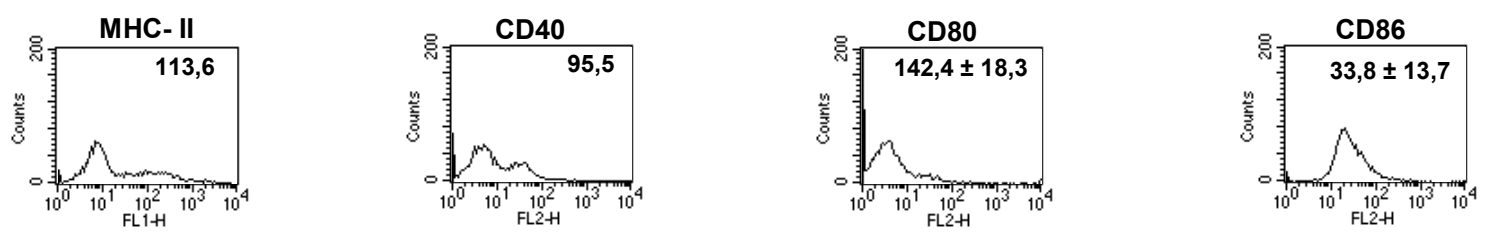

HGG:SBA-15
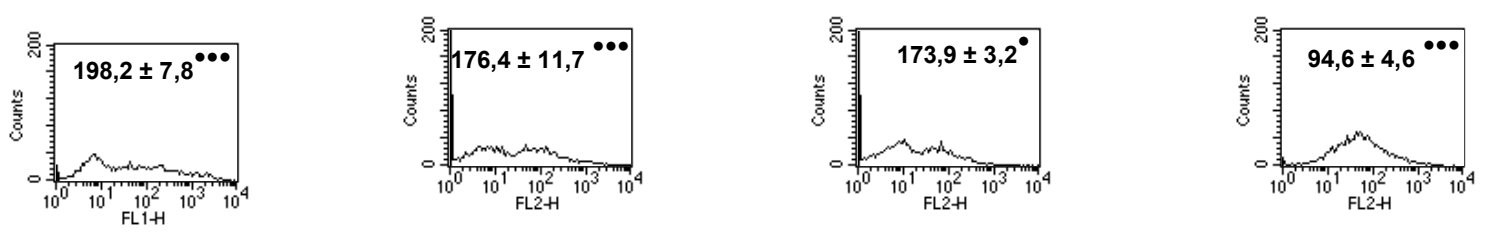

Figura 20 - Expressão das moléculas MHC-II, CD40, CD80 e CD86 nas células $\mathrm{CD} 11 \mathrm{c}^{+}$purificadas de camundongos imunizados com $\mathrm{HGG}$ em $\mathrm{Al}(\mathrm{OH})_{3}$ ou HGG em SBA-15. No $5^{\circ}$ dia pósimunização, células $C D 11 c^{+}$obtidas por seleção positiva a partir de suspensões celulares de linfonodos de camundongos imunizados com $\mathrm{HGG}: \mathrm{Al}(\mathrm{OH})_{3}$ ou $\mathrm{HGG:SBA-15}$, foram incubadas com anticorpos monoclonais anti-MHC-II, anti-CD40, antiCD80 e anti-CD86 ou com anticorpos isotípicos conjugados a FITC ou $\mathrm{PE}$ e analisadas por citometria de fluxo. Todas as amostras foram feitas em duplicatas e os resultados foram expressos em média de intensidade de fluorescência [MIF] \pm desvio padrão e são representativos de 2 experimentos independentes. Controle isotípico FITC [MIF=2,9]; Controle isotípico $\mathrm{PE}[\mathrm{MIF}=3,4]$. Para análise da variância utilizou-se Two-way ANOVA - pós-teste de Bonferroni- ${ }^{\cdots} p$ $<0,001 ; " p<0,05$ - grupo HGG:SBA-15 comparado com HGG:Al(OH $)_{3}$. 


\section{DISCUSSÃO}

A eficiência de uma vacina é determinada pela especificidade, magnitude, duração da imunidade protetora e, sobretudo, indução de memória eficaz. Por mimetizarem a infecção natural, as vacinas com micro-organismos vivos normalmente não requerem a adição de adjuvantes; porém, as compostas por antígenos inativos ou recombinantes necessitam da adição dessas substâncias para indução de resposta imune eficaz.

Adjuvantes podem potencializar a imunogenicidade de um antígeno através da amplificação de qualquer sinal envolvido no processo de ativação da resposta imune. No entanto, um dos efeitos desejados para melhor ativação do sistema imunológico é a indução de citocinas e aumento da expressão de moléculas coestimuladoras por APCs. Essas células desempenham papel importante no transporte de antígenos da periferia para os tecidos linfóides locais. Entretanto, se este não alcançar o órgão linfóide ele é "ignorado" pelas células imunes; isso geralmente ocorre com os antígenos solúveis que falham em induzir resposta imune efetiva (LUDEWIG et al., 2000; EYLES et al., 2003; ZYNKERNAGEL, et al., 1997).

Estudos têm investigado os potenciais biológicos de nanopartículas e, dentre esses, destaca-se a sua capacidade de carrear antígenos (COESTER; NAYYAR; SAMUEL, 2006; DINAUER, et al., 2005). Recentemente, nosso grupo descreveu o potencial adjuvante da sílica nanoestruturada SBA-15, carreando, protegendo e liberando antígenos às células imunes. Sabendo que nanopartículas podem ser transportadas para as células por meio de endocitose (CONNER; SCHMID, 2003), iniciaram-se experimentos in vitro para verificar o efeito da SBA-15 na fagocitose e atividade de macrófagos.

Há duas décadas atrás, Zimmerman, et al. (1986) demonstraram que sílica coloidal diminui o potencial fagocítico de macrófagos e neutrófilos devido à ruptura de membranas dos vacúolos. Nossos resultados indicam que em baixas concentrações [20 a $1000 \mu \mathrm{g} / \mathrm{mL}$ ], a sílica nanoestruturada SBA-15 não alterou as características morfológicas e a atividade fagocítica dos macrófagos

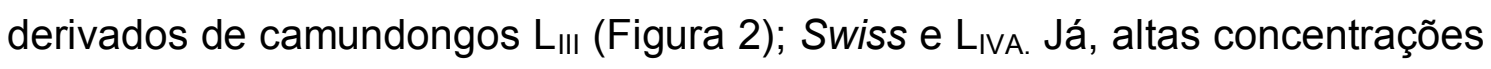
dessa nanopartícula interferem na integridade celular. Salienta-se que a SBA- 
15 possui propriedades físico-químicas que a torna um material atrativo para aplicações biológicas.

Como citado na Introdução, estudos in vivo realizados por nosso grupo mostraram que a SBA-15 foi capaz de modular positivamente a produção de anticorpos de camundongos maus respondedores [L] das Seleções III e IVA, eliminando a diferença interlinhagens [L - H] (CARVALHO, 2007; CARVALHO et al., 2010, prelo). No entanto, experimentos in vitro sugerem que a modulação positiva da resposta imune causada por essa sílica é independente da modificação na atividade dos macrófagos dos camundongos maus respondedores [L], uma vez que essa nanopartícula foi capaz de aumentar a resposta de anticorpos dos camundongos de ambas linhagens, $L_{\text {III }}$ e $L_{\text {IVA. }} A$ redução na porcentagem de macrófagos infectados (Figuras 4 A e B) poderia estar relacionada ao catabolismo dos levedos, no entanto, a SBA-15 não foi capaz de intervir nessa função, pois não houve diferença entre os grupos tratados com diferentes concentrações de sílica comparativamente ao controle (Figuras 4 C e D). Assim, a modulação positiva da resposta de anticorpos em camundongos $L_{\text {III }}$ e $L_{\text {IVA }}$ induzida pela SBA-15 não está relacionada à atividade fagocítica e catabólica dos macrófagos.

Análise da viabilidade e necrose celular através de marcação com $\mathrm{Pl}$, juntamente com os dados de microscopia (Figuras 2 e 3) reafirmam a não toxicidade dessa sílica em baixas concentrações. Como indica a Figura 5, 60\% das células encontram-se não viáveis após incubação com $1500 \mu \mathrm{g} / \mathrm{mL}$ de SBA-15, contudo, esse dado pode estar relacionado ao fato dessa alta concentração de SBA-15 interferir no contato e adesão intercelular, na obtenção de nutrientes presentes no meio, bem como $\mathrm{CO}_{2}$, que são essenciais para a sobrevivência celular. A saturação de sílica no meio foi confirmada por microscopia. Ainda, vale salientar que em experimentos in vivo a concentração máxima dessa nanopartícula utilizada nas imunizações varia de $12 \mu \mathrm{g} / \mathrm{animal}$ a $250 \mu \mathrm{g} /$ animal e, em contato com os fluidos intersticiais essa concentração dilui-se, reduzindo a quantidade de SBA-15 presente no organismo.

Os dados de imunização com a vacina contra Hepatite A em SBA-15 comparativamente aos da vacina e/ou vacina em $\mathrm{Al}(\mathrm{OH})_{3}$ (Figura 6) corroboram os obtidos anteriormente e indicam a eficiência da SBA-15 em promover 
aumento nas respostas secundárias; esses resultados sugerem que essa nanopartícula atue positivamente na expansão e ativação de plasmócitos e linfócitos de memória, essenciais na eficácia de um processo de vacinação.

Estudos físico-químicos sobre a incorporação de BSA à SBA-15 realizados no Laboratório de Cristalografia do Instituto de Física da USP indicaram que o tempo de contato imunógeno:SBA-15 potencializa sua encapsulação/adsorção; ainda, trabalhos demonstram que esse potencial de encapsulação/adsorção relaciona-se com o desenvolvimento de resposta mais efetiva; dessa forma, iniciaram-se estudos com a finalidade de verificar a influência do tempo de contato imunógeno:SBA-15 na produção de anticorpos. Em conjunto, as análises dos resultados ilustrados nas Figuras 7 e 8 demonstram que o tempo é importante para potencializar a adsorção e que essa influencia diretamente na produção de anticorpos, especialmente após dose-reforço. No entanto, tempos superiores a 30 dias poderiam levar a degradação de alguns epítopos e consequentemente diminuir a produção de anticorpos específicos [grupo Hep-A:SBA-15 180 dias - Figura 8]. Ainda, como observado na Figura 1B, os tubos cilíndricos de sílica emaranhados e a larga porosidade e inter-conexão entre os poros, permitem a adsorção e/ou encapsulação dos antígenos dentro e fora; entretanto, o potencial de encapsulação/adsorção da SBA-15 pode variar de acordo com as características físico-químicas e massa molecular do imunógeno a ela encapsulado; no caso da HGG, uma proteína de cerca de $150 \mathrm{kDa}$, cerca de 90,7\% da HGG encontra-se adsorvida à SBA-15 na proporção 1:25. Ressaltase que devido à indisponibilidade da vacina contra Hepatite $A$ e, dada a ação geral adjuvante da SBA-15, seguiram-se estudos utilizando a HGG como imunógeno.

Antígenos particulados são mais eficientemente internalizados pelas APCs que os solúveis; assim sendo, acredita-se que a pré-adsorção de antígenos a adjuvantes aumenta a intensidade da resposta imune (MOREFIELD et al., 2005). Nesse contexto, uma das funções desse material é a conversão de antígenos solúveis em particulados para que sejam facilmente reconhecidos e fagocitados pelas APCs; uma vez capturados por essas células, o antígeno é liberado e em seguida selecionado para apresentação via MHC. Experimentos ex vivo realizados em camundongos imunizados com a 
vacina da Hepatite A adsorvida ou não em SBA-15 mostraram que essa sílica, mesmo na ausência de estímulo antigênico, induz o recrutamento de macrófagos e DCs para os linfonodos drenantes (Figura 9), modulando positivamente a expressão de CD80 nas células de camundongos imunizados com Hep-A:SBA-15 relativamente aos animais que receberam somente a vacina e aos não imunizados (Figura 10). Corroborando esses resultados, verificou-se que a imunização com HGG:SBA-15 induziu aumento na expressão das moléculas coestimuladoras CD40 e CD80 comparativamente à imunização com a proteína em $\mathrm{Al}(\mathrm{OH})_{3}$ e/ou proteína solúvel; ainda, observa-se modulação da expressão de MHC-II relativamente à imunização com proteína solúvel (Figuras 18). Diante desses dados, realizou-se experimento de duplamarcação para saber qual APC apresentou maior expressão de moléculas coestimuladoras. Observou-se que na suspensão celular de camundongos imunizados com HGG:SBA-15 há maior porcentagem de células

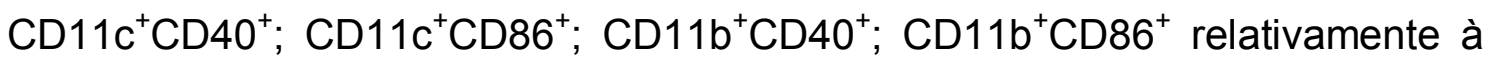
obtida após imunização com HGG:AI $(\mathrm{OH})_{3}$ e/ou HGG:PBS; e, em relação ao grupo HGG:PBS também houve maior porcentagem de células $\mathrm{CD}_{11 \mathrm{c}^{+} \mathrm{e}}$

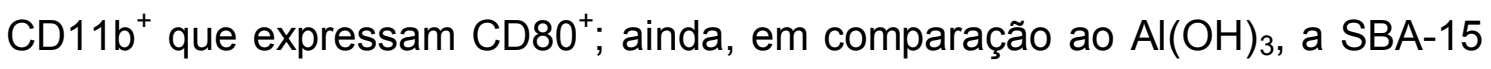
modulou a expressão de CD40 e CD86 nos linfócitos B (Figura 19). Esses dados sugerem que essa nanopartícula facilite o reconhecimento e captura dos antígenos por APCs com consequente ativação dessas células.

Há relatos que DCs são as células responsáveis no aumento da imunogenicidade de antígenos presentes nas vacinas, e dessa forma são consideradas adjuvantes naturais (GUERY et al., 1997; STEINMAN; POPE, 2002). São as mais efetivas APCs e têm o papel crucial na geração da imunidade mediada por linfócitos T (BANCHEREAU; STEINMAN, 1998). Esta habilidade de ativar a resposta primária de linfócitos $\mathrm{T}$ é devido à expressão constitutiva de MHC-II e CD86 nas suas superfícies. Além disso, após serem ativadas, essas células aumentam rapidamente a expressão de marcadores de superfície seguida da expressão de outras moléculas coestimuladoras, como CD80 (CROFT; DUNCAN; SWAIN, 1992; FAGONI et al., 1995; THOMAS; DAVIS; LIPSKY, 1993).

Embora adjuvantes derivados de bactérias tais como LPS, lipídio A e seqüências $\mathrm{CpG}$ sejam descritos como ativadores de DCs, há poucas 
informações sobre o efeito de outros adjuvantes comumente utilizados nessas células (POLTORAK et al. 1998; HEMMI et al., 2000). Estudos mostram que adjuvantes derivados de sais de alumínio, vesículas surfactantes não-iônicas [NISV] e micropartículas de poli [L-ácido láctico-co-ácido glicólico] [PLGA] não aumentam a expressão de moléculas coestimuladoras, nem induzem a maturação de DCs in vitro, apesar de estimularem forte resposta imune antígeno-específica in vivo. Assim, sugere-se que "sinais de perigo" liberados endogenamente ou processos inflamatórios podem ativar indiretamente essas células (SUN; POLLOCK; BREWER, 2003; LI; NOOKALA; RE, 2007; SHI; EVANS; ROCK, 2003).

Estudo de Beamer e Holian (2008) indica que a sílica amorfa não estruturada [Min-U-Sil-S] aumentou a atividade das DCs em apresentar antígenos, no entanto, diminuiu a expressão de CD40, CD86, MHC-II e produção de NO, sendo este efeito dose-dependente. Em contraposição ao efeito in vitro dos adjuvantes derivados de hidróxido/fosfato de alumínio, que são amplamente utilizados na vacinação humana e aos efeitos da sílica amorfa não estruturada [Min-U-Sil-S], experimentos ex vivo com células CD11c ${ }^{+}$ purificadas de linfonodos drenantes de camundongos após 5 dias de imunização com HGG:SBA-15 e/ou HGG:Al(OH) 3 mostram que relativamente ao $\mathrm{Al}(\mathrm{OH})_{3}$, a SBA-15 aumentou a expressão de moléculas MHC-II, CD40, CD80 e CD86 na superfície dessas células (Figura 20). Apesar dos dados da Figura 19 mostrarem que no grupo HGG:SBA-15 há maior porcentagem de outras APCs [CD11b ${ }^{+}$e B220 ${ }^{+}$que expressam CD40, CD80 e CD86, em conjunto, os dados das Figuras 18, 19 e 20 indicam que as células CD11c ${ }^{+}$ podem, nesse contexto, ser as responsáveis pela apresentação dos antígenos aos linfócitos $\mathrm{T}$; assim sugere-se um possível papel das DCs no efeito adjuvante da SBA-15.

Além de recrutar APCs e aumentar a expressão de moléculas coestimuladoras por essas células, os dados das Figuras 9 e 18 mostram, respectivamente, que imunizações com vacina contra Hepatite A em SBA-15; HGG:SBA-15 ou a inoculação dessa sílica também promovem aumento de células $\mathrm{CD}^{+}, \mathrm{CD}^{+}$e $\mathrm{B}^{2} 20^{+}$nos órgãos linfóides envolvidos na resposta à essas imunizações. Observa-se do $3^{\circ}$ ao $7^{\circ}$ dia pósimunização, discreta 
prevalência de células $\mathrm{CD}^{+}$em todos os grupos experimentais e controle (Figura 9 e 17).

Dados de determinação das populações celulares presentes nos linfonodos drenantes após imunização com HGG; HGG:AI(OH) 3 ; HGG:SBA-15 ilustrados na Figura 18 relacionam-se aos das Figuras 11 e 12, onde verificase que tanto a SBA-15 quanto $\mathrm{O} \mathrm{Al}(\mathrm{OH})_{3}$ induziram boa produção de anticorpos. No entanto, resultados de experimentos ex vivo representados nas Figuras 18, 19 e 20 confirmam que apesar do $\mathrm{Al}(\mathrm{OH})_{3}$ induzir efetivamente resposta mediada por anticorpos in vivo, esse adjuvante não potencializa a expressão de moléculas coestimuladoras na superfície das APCs. Ainda, sabese que a interação de CD80 e CD86 com CD28 resulta em sinais coestimulatórios que induzem a ativação, expansão, diferenciação e sobrevivência dos linfócitos $T$, resultando em resposta imune humoral e celular efetiva (GREENWALD; FREEMAN; SHARPE, 2005); assim, a menor expressão de CD80 e CD86, sobretudo na superfície das células CD11c ${ }^{+}$ (Figura 19A) poderia explicar a menor resposta proliferativa de linfócitos $\mathrm{T}$ de camundongos imunizados com $\mathrm{HGG}: \mathrm{Al}(\mathrm{OH})_{3}$ relativamente aos imunizados com HGG:SBA-15.

Como já salientado, o mecanismo de apresentação antigênica pelas APCs pode ocorrer via MHC classes I ou II, dependendo da natureza e dose do antígeno, via de imunização e do adjuvante utilizado para potencializar a resposta. Complexos antigênicos distintos [antígeno + adjuvante] poderão ser processados e apresentados via MHC-Il para os linfócitos TCD4 ${ }^{+}$e assim gerar subpopulações $T_{H}$, como $T_{H} 1$ ou $T_{H} 2$. Nesse contexto, a produção de citocinas derivadas da ativação e/ou maturação de DCs podem influenciar diretamente o padrão de citocinas $T_{H}$ e consequentemente no desenvolvimento da resposta $\mathrm{T}_{\mathrm{H}} 1$ ou $\mathrm{T}_{\mathrm{H}} 2$ (BOTTOMLY, 1999). Na presença de IL-12, as células CD4 ${ }^{+}$se diferenciam em células $T_{H} 1$ produtoras de IFN- $\gamma$ e eficientes na proteção contra patógenos intra-celulares. Entretanto, na presença de IL-4, DCs induzem a diferenciação de células $\mathrm{CD}^{+}$em $\mathrm{T}_{\mathrm{H}} 2$ secretoras de IL-5, IL-4, IL-10 e IL-13 e efetivas na produção de anticorpos (BANCHEREAU; STEINMAN, 1998).

Embora diferentes adjuvantes induzam comparáveis níveis de anticorpos funcionais, o respectivo padrão de citocinas e isótipos de anticorpos é distinto e, em certas situações o tipo de resposta induzida $T_{H} 1$ ou $T_{H} 2$ poderá ter 
significativo impacto na proteção efetiva da vacina (O'HAGAN; MacKICHAN; SINGH, 2001). Alguns adjuvantes tendem a favorecer um tipo específico de resposta, no entanto, a finalidade dessa substância é potencializar, sem interferir, a resposta imune específica sendo assim eficaz na proteção contra diferentes patógenos.

Os dados da Figura 12 confirmam os obtidos anteriormente por nosso grupo e revelam que antígenos de natureza distinta [Int1ßr; BSA; vírus da Hepatite A e B; HGG] em SBA-15 administrados por diferentes vias, induziram, sem predominância, a produção dos isótipos lgG1 e IgG2a. Desta forma sugere-se que essa nanopartícula não direciona qualitativamente a resposta imune humoral. Corroborando esses resultados, a análise da produção de citocinas nos sobrenadantes de células de camundongos imunizados com HGG; HGG:SBA-15; HGG:Al(OH) 3 e/ou inoculados com SBA-15 após diferentes reestímulos (Figura 13 a 15) demonstra que a sílica isoladamente não é capaz de ativar o sistema imune adaptativo e não influencia qualitativamente no desenvolvimento da resposta imune. As análises de produção de IL-2 nas células dos camundongos imunizados com HGG; HGG:SBA-15; HGG:Al(OH) ${ }_{3}$ e/ou inoculados com SBA-15 (Figura 13), indicam proliferação celular mesmo na ausência de estímulo antigênico, pois na presença de meio de cultura verifica-se secreção dessa citocina. Ainda, células dos grupos HGG; HGG:SBA-15; HGG:Al(OH) 3 , após estímulo mitogênico, secretaram menor quantidade de IL-2 quando comparada às células dos animais não imunizados (Figura 13), o que sugere o consumo de parte de IL-2 secretada. 


\section{CONCLUSÃO}

A resposta de linfócito $\mathrm{T}$ a um determinado antígeno é um processo complexo no qual citocinas e moléculas coestimuladoras fornecem sinais que dirigem o desenvolvimento da imunidade adaptativa durante o contato entre linfócitos e APCs. Em conjunto, os resultados de fenotipagem celular nos órgãos linfóides, bem como a expressão de moléculas coestimuladoras e produção de citocinas, sugerem que a SBA-15 facilite o reconhecimento e captura de antígenos pelas APCs, especialmente DCs, as quais processam o antígeno e tornam-se funcionalmente maduras sendo eficientes na ativação de linfócitos $T$ antígenos-específicos virgens dando início a geração da resposta imune adquirida. Ainda, as características físico-químicas e massa molecular do imunógeno, bem como o tempo de contato com a SBA-15, influenciam o grau de encapsulação/adsorção e, consequentemente, no potencial adjuvante dessa nanoestrutura. 


\section{REFERÊNCIAS ${ }^{1}$}

AICHELE, P.; BRDUSCHA-RIEM, K.; ZINKERNAGEL, R. M.; HENGARTNER, $\mathrm{H}$.; PIRCHER, H. T cell priming versus $T$ cell tolerance induced by synthetic peptides. J. Exp. Med., v. 182, p. 261-266, 1995.

ALLISON, A. C.; HARINGTON, J. S.; BIRBECK, M. An examination of the cytotoxic effects of silica on macrophagos. J. Exp. Med., v. 124, p. 141-154, 1966.

ALVING, C. R. Design and selection of vaccine adjuvants:animal models and human trials. Vaccine, v. 20, p.56-64, 2002. Suppl 3.

ARDAVIN, C. Origin, precursos and differentiation of mouse dendritic cells. Nat. Rev. Immunol., v. 3, p. 582-590, 2003.

ARKWRIGHT, P. D.; DAVID, T. J. Intradermal administration of a killed Mycobacterium vaccae suspension [SRL 172] associated with improvement in atopic dermatitis in children with moderate-to-severe disease. J. Allergy Clin. Immunol., v. 107, p. 531-534, 2001.

BANCHEREAU, J.; STEINMAN, R. M. Dendritic cells and the control of immunity. Nature, v. 392, p. 245-252, 1998.

BEAMER, C.A.; HOLIAN, A. Silica suppresses Toll-like receptor ligandinduced dendritic cell activation. FASEB J., v. 22, n. 6, p. 2053-2063, 2008.

BECKER, L. J.; RUDBACH, J. A. Altered antibody responses in mice treated with toxins for macrophages. Reticuloendoth Soc., v. 25, p. $443-454,1979$.

BELKAID, Y.; ROUSE, B.T. Natural regulatory $T$ cells in infectious disease. Nature immunol., v. 6, p. 353-360, 2005.

BIOZZI, G.; MOUTON, D.; STIFFEL, C.; BOUTHILLIER, Y. A major role of the macrophage in quantitative genetic regulation of immunoresponsiveness and anti-infectious immunity. Adv. Immunol., v. 36, p. 189-234, 1984.

\footnotetext{
${ }^{1}$ De acordo com: ASSOCIAÇÃO BRASILEIRA DE NORMAS TÉCNICAS. NBR 6023: Informação e documentação: referências: elaboração. Rio de Janeiro, 2002.
} 
BIOZZI, G.; CABRERA, W. H.; MOUTON, D.; IBANEZ, O. M. Restricted and general polygenic regulation of antibody responsiveness. In: BENACERRAF $B$. (Ed.). Immunogenetics and Immune regulation. Milan: Masson, 1982. p. 3160.

BIOZZI, G.; MOUTON, D.; SANT'ANNA, O. A.; PASSOS, H. C.; GENNARI, M.; REIS, M. H.; FERREIRA, V. C. A.; HEUMANN, A. M.; BOUTHILLIER, Y.; IBANEZ, O. M.; STIFFEL, C.; SIQUEIRA, M. Genetics of immunoresponsiveness to natural antigens in the mouse. Curr. Top. Microbiol. Immunol., v. 85, p. 31-98, 1979.

BOTTOMLY, K. T cells and dendritic cells get intimate. Science, v. 283, p. 1124-1125, 1999.

BREWER, J. M. (How) do aluminium adjuvantes work? Immunol. Lett., v. 102, n. 1, p, 10-15, 2006.

CABRERA, W. H.; IBANEZ, O. M.; OLIVEIRA, S. L.; SANT'ANNA, O. A.; SIQUEIRA, M.; MOUTON, D.; BIOZZI, G. Evidence for distinct polygenic regulation of antibody responses to some unrelated antigens in lines of mice selected for high or low antibody responses to somatic antigen of Salmonella. Immunogenetics, v. 16, p. 583-592, 1982.

CARVALHO, L. V. Estudo experimental do efeito adjuvante da sílica nanoestruturada SBA-15. 2007. 81f. Dissertação (Mestrado em Imunologia) Instituto de Ciências Biomédicas, Universidade de São Paulo, São Paulo, 2007.

CARVALHO, L. V.; RUIZ, R. C.; SCARAMUZZI, K.; MARENGO, E. B.; MATOS, J. R.; TAMBOURGI, D. V.; FANTINI, M. C. A.; SANT'ANNA, O. A. Immunological parametres related to the adjuvant effect of the ordered mesoporous silica SBA-15. Vaccine, 2010. In press.

CEBON, J.; JAGER, E.; SHACKLETON, M. J.; GIBBS, P.; DAVIS, I. D.; HOPKINS, W., et al. Two phase I studies of low dose recombinant human IL-12 with Melan-A and influenza peptides in subjects with advanced malignant melanoma. Cancer Immun., v. 3, p. 7-25, 2003.

CLEMMENSEN, O.; KNUDSEN, H. E. Contact sensitivity to aluminium in a patient hyposensitized with aluminium precipitated grass polen. Contact Dermatitis, v. 5, p. 305-308, 1980. 
COESTER, C.; NAYYAR, P.; SAMUEL, J. In vitro uptake of gelatin nanoparticles by murine dendritic cells and their intracellular localization. Eur. $\mathbf{J}$. Pharm. Biopharm., v. 62, p. 306-314, 2006.

COLLIER, L. H.; POLAKOFF, S.; MORTIMER, J. Reactions and antibody responses to reinforcing doses of adsorbed and plain tetanus vaccines. Lancet, v. 1, p. $1364-1368,1979$.

CONNER, S. D.; SCHMID, S. L. Regulated portals of entry into the cell. Nature, v. 422, n. 6927, p. 37-44, 2003.

CROFT, M.; DUNCAN, D.; SWAIN, S. Response of naïve antigen specific CD4+ T cells in vitro: Characteristics and antigen-presenting cell requirements. J. Exp. Med., v. 176, p. 1431-1437, 1992.

DE ALMEIDA, V. S.; TAKATA, C. S.; SANT'ANNA, OA; LOPES, A. C.; DE ARAUJO, P. S.; DA COSTA, M. H. B. Enhanced liposomal vaccine formulation and performance: simple physicochemical and immunological approaches. J. Liposome Res., v. 16, n. 3, p. 215-227, 2006.

DEGEN, W. G.; JANSEN, T.; SCHIJNS, V. E. Vaccine adjuvant technology: from mechanistic concepts to practical applicatinos. Exp. Rev. Vaccines, v. 2, p. 327-335, 2003.

DINAUER, N.; BALTHASAR, S.; WEBER, C.; KREUTER, J.; LANGER, K.; vON BRIESEN, $H$. Selective targeting of antibody-conjugated nanoparticles to leukemic cells and primary T-lymphocytes. Biomaterials, v. 26, p. 5898-5906, 2005.

DRANOFF, G. GM-CSF-based cancer vaccines. Immunol. Rev., v. 188, p. 147-154, 2002.

EDELMAN, R. The development and use of vaccine adjuvants. Mol. Biotechnol., v. 21, p. 129-148, 2002.

EDELMAN, R.; TACKET, C. O. Adjuvants. Intern. Rev. Immunol., v. 7, p. 5166, 1990. 
ENGVALL, E.; PERLMAN, P. Enzyme-linked immunosorbent assay (ELISA): quantitative assay of immunoglobulin G. Immunochemistry, v. 8, p. 871-874, 1971.

ERODOHAZI, M.; NEWMAN, R. L. Aluminium hydroxide granuloma. Braz. Med. J., v. 3, p. 621-623, 1971.

EYLES, J. E.; CARPENTER, Z. C.; ALPAR, H. O.; WILLIAMSON, E. D. Immunological aspects of polymer microsphere vaccine delivery systems. $\mathbf{J}$. Drug Target, v. 11, p. 509-514, 2003.

FAGONI, F.; TAKAMIZAWA, M.; GODFREY, W.; RIVAS, A.; AZUMA, M.; OKUMURA, K.; ENGLEMAN, E. Role of B70/B7-2 in CD4+ T-cell immune responses induced by dendritica cells. Immunology, v. 85, p. 467-474, 1995.

FERREIRA, V.; GENNARI, M.; REIS, M. H. Potentialities of immunocompetent cells in high and low antibody-producing line of mice obtained by selective breeding for responsiveness to flagellar or somatic antigens of Salmonellae. J. Immunogenet., v. 12, p. 309-319, 1985.

FROST, L.; JOHANSEN, P.; PEDERSEN, S.; VEIEN, N.; OSTERGAARD, P. A.; NIELSEN, M. H. Persistent subcutaneous nodules in children hyposensitized with aluminium-containing allergen extracts. Allergy, v. 40, p. 368-372, 1985.

GENNARI, M.; BOLTHILLIER, Y.; IBANEZ, O. M.; FERREIRA, V. C. A.; MEVEL, J. C.; REIS, M. A.; PIATTI, R. M.; RIBEIRO, O. G.; BIOZZI, G. Effect of silica on the genetic regulation of antibody responsiveness. Ann. Inst. Pasteur Immunol., v. 138, p. 359-370, 1987.

GERMAIN, R. N.; MARGULIES, D. H. The biochemistry and cell biology of antigen processing and presentation. Annu. Rev. Immunol., v. 11, p. 403-450, 1993.

GERY, I.; LEPE-ZUNIGA, J. L. Interleukin 1: Uniqueness of its production and spectrum of activities. Lymphokines., v. 9, p. 109-125, 1984.

GREENWALD, R. J.; FREEMAN, G. J; SHARPE, A. H. The B7 family revisited. Annu. Rev. Immunol., v. 23, p. 515-548, 2005. 
GUERY, J. C.; RIA, F.; GALBIATI, F.; SMIROLDO, S.; ADORINI, L. The mode of protein antigen administration determines preferential presentation of peptide-Class II complexes by lympho node dendritic or B cells. Int. Immunolo., v.9, p. 9-15, 1997.

GUPTA, R. K.; RELYVELD, E. H.; LINDBLAD, E. B.; BIZZINI, B.; BENEFRAIM, S. GUPTA, C. K. Adjuvants - a balance between toxicity and adjuvanticity. Vaccine, v. 11, p. 293-306, 1993.

HADJIPETROU-KOUROUNAKIS, L.; MÖLLER, E. Adjuvants influence the immunoglobin subclass distribution of immune responses in vivo. Scand. J. Immunol., v. 19, p. 219-225, 1984.

HARDING, F. A.; MCARTHUR, J. G.; GROSS, J. A.; RAULET, D. H.; ALLISON, J. P. CD-28 mediated signaling costimulates murine $T$ cells and prevents induction of anergy in T-cell clones. Nature, v. 356, p. 607-609, 1992.

HARRINGTON, L.E.; MANGAN, P.R.; WEAVER, C.T. Expanding the effector CD4 T-cell repertoire: the $T_{H} 17$ lineage. Curr. Opin. Immunol., v. 18, p. 349356, 2006.

HATCOCK, K. S.; LASZLO, G.; PUCILLO, C.; LINSLEY, P.; HODES, R. J. Comparative analysis of B7.1 and B7.2 costimulatory ligands: expression and function. J. Exp. Med., v. 180, p. 631-640, 1994.

HEMMI, H. TAKEUCHI, O.; KAWAI, T. A toll-like receptor recognizes bacterial DNA. Nature, v. 408, p. 740-745, 2000.

JANEWAY, C. Jr.; TRAVERS, P.; WALPORT, M.; SHLOMCHIK, M. The adaptive immune response host defense against infection. In:

Immunobiology: the immune system in health and disease. 5th. ed. New York: Garland Publishing, 2001. p. 436-442.

JONDAL, M.; SCHIRMBECK, R.; REIMANN, J. MHC class I-restricted CTL responses to exogenous antigens. Immunity, v. 5, p. 295-302, 1996.

JORDAN, M.B. Promotion of B cell immune responses via an alum-induced myeloid cell population. Science, v. 304, p. 1808-1810, 2004. 
KAMPSCHMIDT, R. F.; WORTHINGTON, M. L.; MESECHER, M. I. Release of interleukin-1 (il-1) and il-1-like factors from rabbit macrophages with silica. J. Leukocyte Biol., v. 39, p. 123-132, 1986.

KELLEHER, P.; MAROOF, A.; KNIGHT, S. C. Retrovirally induced switch from production of IL-12 to IL-4 in dendritic cells. Eur. J. Immunol., v. 29, p. 23092318, 1999.

KRESGE, C. T.; LEONOWIEZ, M. E.; ROTH, W. J.; VARTULI, J. C.; BECK, J. $\mathrm{S}$. Ordered mesoporous molecular sieves synthesized by a liquid-crystal template mechanism. Nature, v. 359, p. 710-712, 1992.

LI, H. S.; NOOKALA, S.; RE, F. Aluminum hydroxide adjuvants activate caspase-1 and induce IL-1b AND IL-18 release. J. Immunol., v. 178, p. 52715276, 2007.

LINDBLAD, E. B. Aluminium compounds for use in vaccines. Immunol. Cell Biol., v.82, p. 497-505, 2004.

LOTZOVA, E.; CUDKOWICZ, G. Abrogation of resistance to bone marrow grafts by silica particles. J. Immunol., v. 113, p. 798-803, 1974.

LUDEWIG, B.; BARCHIESI, F.; PERICIN, M.; ZINKERNAGEL, R. M.; HENGARTNER, H.; SCHWENDENER, R. A. In vivo antigen loading and activation of dendritic cells via a liposomal peptide vaccine mediates protective antiviral and anti-tumour immunity. Vaccine, v. 19, p. 23-32, 2000.

MATOS, J. R.; MERCURI, L. P.; KRUK, M.; JARONIEC, M. Toward the Synthesis of Extra-Large-Pore MCM-41 Analogues. Chem. Mater., v. 13, p. 1726-1731, 2001.

MATOUSEK, M. P.; NEDRUD, J. G.; HARDING, C. V. Distinct effects of recombinant cholera toxin $B$ subunit and holotoxin on different stages of class II $\mathrm{MHC}$ antigen processing and presentation by macrophages. J. Immunol., v. 156, p. 4137-4145, 1996.

McClUSKIE, M. J.; WEERATNA, R. D. Novel adjuvant systems. Curr. Drug Targets Infect. Disord., v. 1, p. 263-271, 2001. 
MERCURI, L. P.; CARVALHO, L. V.; LIMA, F. A.; QUAYLE, C.; FANTINI, M. C. A.; TANAKA, G. S.; CABRERA, W. H.; FURTADO, M. F. D.; TAMBOURGI, D. V.; MATOS, J. R.; JARONIEC, M.; SANT'ANNA, O. A. Ordered mesoporous to silica SBA-15: A new effective adjuvant to induce antibody response. Small, $n$. 2, p. 254-256, 2006.

MOREFIELD, G. L.; SOKOLOVSKA, A.; JIANG, D.; HOGENESCH, H.; ROBINSON, J. P.; HEM, S. L. Role of aluminum-containing adjuvants in antigen internalization by dendritic cells in vitro. Vaccine, v. 23, p. 1588-1595, 2005.

MOSMANN, T. R.; COFFMAN, R.L. Th1 and Th2 cells: Different patterns of lymphokine secretion lead to different functional properties. Annu. Rev. Immunol., v. 7, p. 145-173, 1989.

MOSMANN, T. R.; SAD, S. The expanding universe of T cell subsets: Th1, Th2 e mais. Immunol. Today, v. 17, p. 138-145, 1996.

O'HAGAN, D.T.; MacKICHAN, M.L.; SINGH, M. Recent developments in adjuvants for vaccine against infectious diseases. Biomolecular Engineering, v. 18, p. 69-85, 2001.

O'GARRA, A. Cytokines induce the development of functionally heterogeneous T helper cell subsets. Immunity, v. 8, p. 275-283, 1998.

PODDA, A.; DEL GIUDICE, G. MF-59-adjuvanted vaccines: increased immunogenicity with an optimal safety profile. Expert Rev. Vaccines, v. 2, p. 197-203, 2003.

POLTORAK, A.; HE, X.; SMIRNOVA, I. Defective LPS signaling in C3H/HeJ and C57BL/10 ScCr mice: mutations in TIr4 gene. Science, v. 282, p 20852088, 1998.

QUINTILIO, W.; TAKATA, C. S.; SANT'ANNA, O. A.; DA COSTA, M. H. B; RAW, I. Evaluation of a diphtheria and tetanus PLGA microencapsulated vaccine formulation without stabilizers. Curr. Drug. Deliv., v. 6, n. 3, p. 297304, 2009.

SANT'ANNA, O. A.; FERREIRA, V. C.; REIS, M. H.; GENNARI, M.; IBANEZ, O. M.; ESTEVES, M. B.; MOUTON, D.; BIOZZI, G. Genetic parameters of the 
polygenic regulation of antibody responsiveness flagellar and somatic antigens os Salmonellae. J. Immunogenet., v. 3, p. 191-205, 1982.

SCARAMUZZI, K. Efeito adjuvante da sílica mesoporosa nanoestruturada SBA-15 na imunização pela via oral. 2009. 74. f. Dissertação (Mestrado em Imunologia) - Instituto de Ciências Biomédicas, Universidade de São Paulo, São Paulo, 2009.

SHI, Y. J.; EVANS, J. E.; ROCK, K. L. Molecular identification of a danger signal that alerts the immune system to dying cells. Nature, v. 425, p. 516-521, 2003.

SILVA, S. R.; JACYSYN, J. F.; MACEDO, M. S.; FAQUIM-MAURO, E. L. Immunosupressive components of Ascaris sum down-regulate expression of costimulatory molecules and function of antigen-presenting cells via an IL-10mediated mechanism. Eur. J. Immunol., v. 36, p. 3227-3237, 2006.

SIQUEIRA, M.; ESTEVES, M. S.; IBANEZ, O. M; FERREIRA, V. C. A.; SANT'ANNA, O. A.; REIS, M. H.; BIOZZI, G. Nonspecific genetic regulation of antibody responsiveness in the mouse. Europ. J. Immunol., v. 7, p. 195-203, 1977.

SMITH II, J. W.; WALKER, E. B.; FOX, B. A.; HALEY, D.; WISNER, K. P.; DORAN, T., et al. Adjuvant immunization of HLA-A2-positive melanoma patients with a modified gp100 peptide induces peptide-specific CD8+ T-cell responses. J. Clin. Oncol., v. 21, p. 1562-1573, 2003.

STEINMAN, R. M.; POPE, M. Exploiting dendritic cells to improve vaccine efficacy. J. Clin. Invest., v. 109, p. 1519-26, 2002.

STRAW, B. E.; MACHLACHLAN, N. J.; CORBETT, W. T.; CARTER, P. B.; SCHEY, M. H. Comparison of tissue reactions produced by Haemophilus pleuropneumoniae vaccines made with 6 different adjuvants in swine. Can. J. Comp. Med., v. 49, p. 149-151, 1985.

SUN, H.; POLLOCK, K. G.; BREWER, J. M. Analysis of the role of vaccine adjuvants in modulating dendritic cell activation and antigen presentation in vitro. Vaccine, v. 21, p. 849-855, 2003. 
THOMAS, R.; DAVIS, L.; LIPSKY, P. Comparative accessory cell function of human peripheral blood dendritic cell and monocytes. J. Immunol., v. 151, p. 6840-6852, 1993.

TRINCHIERI, G. Interleukin-12: a proinflammatory cytokine with immunoregulatory functions that bridge innate resistance and antigen-specific adaptative immunity. Ann. Rev. Immunol., v. 13, p. 251-276, 1995.

ULMER, J.B.; VALLEY, U.; RAPPUOLI, R. Vaccine manufacturing: challenges and solutions. Nature Biotechnol., v. 24, p. 1377-1383, 2006.

VERNACCHIO, L.; BERNSTEIN, H.; PELTON, S.; ALLEN, C.; MACDONALD, K.; DUNN, J, et al. Effect of monophosphoryl lipid A [MPL] on T-helper cells when administered as an adjuvant with pneumocococcal-CRM197 conjugate vaccine in healthy toddlers. Vaccine, v. 20, p. 3658-3667, 2002.

VOGEL, S. N.; ENGLISH, K. E.; O'BRIEN, A. D. Silica enhancement of murine endotoxin sensitivity. Infect. Immun., v. 38, p. 681-685, 1982.

WAITE, D. C.; JACOBSON, E. W.; ENNIS, F. A.; EDELMAN, R.; WHITE, B.; KAMMER, R., et al. Three double-blind, randomized trials evaluating the safety and tolerance of different formulations of the saponin adjuvant Qs-21. Vaccine, v. 19, p. 3957-3967, 2001.

WANG, H.B.; WELLER, P.F. Pivotal advance: eosinophils mediate early alum adjuvant-elicited B cell priming and IgM production. J. Leukoc. Biol., v. 83, p. 817-821, 2008.

WEINER, G. J. The immunobiology and clinical potential of immunostimulatory CpG oligodeoxynucleotides. J. Leukoc. Biol., v. 68, p. 455-463, 2000.

WOLF, P. R.; PLOEGH, H. L. How MHC class II molecules acquire peptide cargo: biosynthesis and trafficking through the endocytic pathway. Annu. Rev. Cell Dev. Biol., v. 11, p. 267-306, 1995.

YANG, H.; COOMBS, N.; OZIN, G. A. Morphogenesis of shapes and surface patterns in mesoporous silica. Nature, v. 386, p. 692-695, 1997.

YORK, I. A.; ROCK, K. L. Antigen processing and presentation by the class I major histocompatibility complex. Annu. Rev. Immunol., v. 14, p. 369-396, 1996. 
ZHAO, D.; HUO, Q.; FENG, J.; CHMELKA, B. F.; STUCKY, G. D. Nanionic triblock and star diblock copolymer and surfactant syntheses of highey ordered, hydrothermally stable, mesoporous silica structures. J. Am. Chem. Soc., v. 120 , p. $6024-6036,1998$.

ZHAO, D.; FENG, J.; HUO, Q.; MELOSH, N.; FREDRICKSON, G. H.; CHMELKA, B. F.; STUCKY, G. D. Triblock copolymer synthese of mesoporous silica with periodic 50 to 300 angstrom pores. Science, v. 279, p. 548-552, 1998b.

ZIMMERMAN, B. T.; CANONO, B. P.; CAMPBELL, P. A. Silica decreases phagocytosis and bactericidal activity of both macrophages and neutrophils in vitro. Immunology, v. 59, p. 521-525, 1986.

ZINKERNAGEL, R. M.; EHL, S., AICHELE, P.; OEHEN, S.; KUNDIG, T.; HENGARTNER, $\mathrm{H}$. Antigen localisation regulates immune responses in a doseand time-dependent fashion: a geographical view of immune reactivity. Immunol. Rev., v. 156, p. 199-209, 1997. 


\section{ANEXO - ARTIGO DE PERIÓDICO}

Artigo 1 CARVALHO, L. V.; RUIZ, R. C.; SCARAMUZZI, K.; MARENGO, E. B.; MATOS, J. R.; TAMBOURGI, D. V.; FANTINI, M. C. A.; SANT'ANNA, O. A. Immunological parametres related to the adjuvant effect of the ordered mesoporous silica SBA-15. Vaccine, 2010. In press. 


\title{
Immunological parameters related to the adjuvant effect of the ordered mesoporous silica SBA-15
}

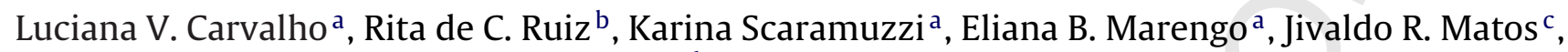 \\ Denise V. Tambourgi ${ }^{a}$, Marcia C.A. Fantini ${ }^{\mathrm{d}}$, Osvaldo A. Sant'Anna ${ }^{\mathrm{a}, *}$ \\ a Immunochemistry Laboratory, Butantan Institute, Av. Vital Brazil, 1500, Sao Paulo, SP 05503-900, Brazil \\ b Bacteriology Laboratory, Butantan Institute, Sao Paulo, SP 05503-900, Brazil \\ c Chemistry Institute, University of Sao Paulo, Sao Paulo, SP 05599-970, Brazil \\ d Physics Institute, University of Sao Paulo, Sao Paulo, SP 05599-970, Brazil
}

\section{A R T I C L E I N F O}

\section{Article history:}

Received 24 May 2010

Received in revised form

17 September 2010

Accepted 26 September 2010

Available online $\mathrm{xxx}$

\section{Keywords:}

Adjuvant

Immunogenicity

Immunological memory

\begin{abstract}
A B S T R A C T
In 2006, the first report of a nanostructured material as adjuvant was described establishing the effectiveness of the ordered mesoporous SBA-15 silica as an immune adjuvant. The present study evaluated the SBA-15 capacity to modulate the immune responsiveness of High and Low responder mice immunized with BSA encapsulated/adsorbed in SBA-15 by the intramuscular or oral route and the adjuvant effect was compared with the responsiveness induced by BSA in aluminum hydroxide salts or emulsified in Incomplete Freund adjuvant. These results demonstrate the ability of the non-toxic SBA-15 nanoparticles to increase the immunogenicity and repair the responsiveness of the constitutively low responder individuals inducing both the IgG2a and the IgG1 isotypes, independently of the immune cell committed and conditioning the low phenotype. Ths new adjuvant may reveal novel therapeutic targets for immune modulation and vaccine design.
\end{abstract}

(c) 2010 Published by Elsevier Ltd.

\section{Introduction}

Generation of specific immune responses against infectious diseases is a primary goal of vaccination and the elucidation of the mechanisms related to antigen recognition offers a variety of strategies for the rational design of vaccines. This knowledge involves the understanding of complex interactions of relevant epitopes with cells, such as macrophages [M $\phi]$, dendritic cells [DC] and epithelial cells. Nowadays, it is possible to evaluate and select immunogens for vaccine formulations based on the molecular interactions of its components. In this regard, the development and study of adjuvants and delivery systems are crucial to engender relevant biological interactions, leading to proficient antigen traffic and pathway activation for a high immunogenicity [1].

Adjuvants have been developed to improve the immunogenicity of inactive non-replicating vaccines, recombinant products or synthetic peptides increasing the responsiveness to naturally low or non-immunogenic antigens. Moreover, the enhancement of responses in low responder individuals, such as elderly or immunosuppressed and the modulation of inappropriate immune

\footnotetext{
This research is under the scope of the International Patent WO 07030901.

* Corresponding author. Tel.: +55 113726 7222x2001; fax: +55 1137261505

E-mail address: gbrazil@usp.br (O.A. Sant'Anna).
}

responses would be expected by the use of adjuvants; therefore, they should elicit early, high and long-lasting protective immunity [1-3]. In addition, the releasing of minor antigen amounts inducing a high-quality of immune response with the adjuvant will probably reduce the impact of selective pressure exerted by a vaccine on pathogenicity. Appropriate adjuvants formulation might interfere in activation/modulation of immunocompetent cells such as DC and B lymphocytes enhance the MHC class I presentation for optimal cytotoxic T lymphocyte [CTL] responses, increasing longterm memory and providing a general mild inflammatory stimulus [1-3].

Some substances such as monophosphoryl-lipid A [MPL] [4], saponin QS-21 [5], as well as combination of these compounds [6] are in late stage clinical trials, currently the oil-in-water emulsion MF59 and the aluminum salts such as aluminum phosphate or sulphate are the most applied for human use $[7,8]$. Nevertheless, aluminum salts induce mainly $\mathrm{T}_{\mathrm{H}} 2$ responses, which provide a less efficacious immune response to the majority of licensed vaccines [8]. Thus, the development of less toxic and more effective vaccine adjuvants seems to be of importance.

The ordered mesoporous SBA-15 silica is an efficient adjuvant candidate. This inorganic substance is usually synthesized under acidic conditions by self-assembly of silica species with a tri-block copolymer as structure-directing agent $[9,10]$. SBA-15 possesses hexagonal porous uniformity, thermal and hydrothermal stabil- 

catalysis [11]. In 2006 we demonstrated that SBA(15 behaves as an adjuvant inducing a better or similar response in BALB/C or genetically selected High [H] and Low [L] mice immunized with E. coli bacterial protein $[\operatorname{Int} 1 \beta]$ or a complex proteins spectrum of Micrurus venom in comparison to a commonly used adjuvant for animal application, such as the complex oil Incomplete Freund Adjuvant [IFA]. Moreover, SBA-15 is able to evoke immunological memory essential for successful vaccinations. These characteristics are believed to be due to the specific adjuvant physical and structural properties [12].

High $[\mathrm{H}]$ and Low $[\mathrm{L}]$ antibody responder mouse lines, obtained by genetic selective breeding according to these phenotypes, differ in cellular mechanisms responsible for the immunobiological characters according to immunogens and immunization procedures used in each genetic selection experiment [13-15]. In Selection IVA, the difference in antibody responsiveness is mainly due to the antigen catabolism of macrophages and probably other antigen presenting cells [APC] that is higher in $\mathrm{L}_{\text {IVA }}$ than in $\mathrm{H}_{\text {IVA }}$ responder lines [13,16]; in Selection III, the H-L difference is due to intrinsic genetic modifications of B lymphocyte potentialities [17]. It was showed that administration of the colloidal silica strongly increases antibody responsiveness in $\mathrm{L}_{\text {IVA }}$ but not in $\mathrm{L}_{\text {III }}$ mice; in $\mathrm{H}_{\text {III }}$ and $\mathrm{H}_{\text {IVA }}$ the effect of this silica is absent [18]. Moreover, it was reported that exposure to amorphous silica decreased the phagocytic capacity of macrophages and neutrophils [19].

The present study broadens the potential use of adjuvant nanoparticles. Here, the adjuvant effect of SBA-15 was compared with the two other here described: the licensed adjuvant for human use, $\mathrm{Al}(\mathrm{OH})_{3}$, and the potent oil mixture, the IFA. The modulation of $\mathrm{L}$ and $\mathrm{H}$ mice responsiveness was determined by intramuscular or oral routes, after primary and secondary immunizations with bovine serum albumin [BSA] encapsulated and/or adsorbed in SBA-15, adsorbed in $\mathrm{Al}(\mathrm{OH})_{3}$, or emulsified in IFA. The results clearly ascertain that SBA-15 improves the immunogenicity and positively modulated the immune response of low responder individuals, which were converted into high antibody producers. Moreover, contrasting with the selective $\mathrm{T}_{\mathrm{H}} 2$ cell subpopulation activations by IFA and mainly $\mathrm{Al}(\mathrm{OH})_{3}$, the nanostructured silica stimulates mutually $\mathrm{T}_{\mathrm{H}} 1$ and $\mathrm{T}_{\mathrm{H}} 2$ immune responses. In vitro assays with macrophages demonstrated that SBA-15 did not affect cells integrity and the phagocytic potential of these APC of distinct mouse lines [Swiss, $\mathrm{L}_{\text {III, }}$ and $\mathrm{L}_{\mathrm{IVA}}$ ]. Definitively, data confirm that nanostructured SBA-15 is effective as adjuvant for vaccine delivery, able to improve the antibody responsiveness.

\section{Materials and methods}

\subsection{SBA-15 synthesis}

SBA-15 was synthesized using poly[ethylene oxide]-poly[propylene oxide]-poly[ethylene oxide] triblock copolymer [Pluronic P123, $\mathrm{EO}_{20} \mathrm{PO}_{70} \mathrm{EO}_{20}, \mathrm{PM}=5800-\mathrm{BASF}$, tetraethyl orthosilicate [TEOS] supplied by Fluka, and hydrochloric acid purchased from Fisher Scientific. The synthesis recipe and adsorption characterization of the sample were analogous to those reported elsewhere [11]. The small-angle X-ray scattering [SAXS] characterization was performed as in a previous work [20].

\subsection{Animals}

Mice were maintained at the animal facility of the Immunochemistry Laboratory of Butantan Institute and caged and handled

under ethical conditions, according to international rules of animal care by the International Animal Welfare Recommendations [21]. Female mice genetically selected for high [H] and low [L] antibody response of Selection III [14,17] and IVA [13,14] were obtained from the Immunogenetic Laboratory of Butantan Institute and Swiss mice from the animal facilities of Butantan Institute. Mice were kept in a room with controlled lighting [ $12 \mathrm{~h}$ light/dark cycle], pressure and humidity.

\subsection{Cell culture and yeast suspensions}

Bone marrow-derived macrophages [BMM $\phi$ ] were generated from bone marrow stem cells cultured on 10-cm-diameter plastic plates for 7 days in RPMI 1640 medium containing 15 mM of HEPES, $2 \mathrm{~g}$ of sodium bicarbonate/liter, and $1 \mathrm{mM}$ L-glutamine and supplemented with $20 \%$ fetal bovine serum and 30\% L929 cell conditioned medium [LCCM]. Differentiated BMM $\phi$ were removed from the substrate by vigorous pipetting of ice-cold phosphate-buffered saline. Cells were counted, added $\left[2 \times 10^{5}\right.$ cells $\left./ \mathrm{mL}\right]$ to glass coverslips [13 mm] inserted in 24-well tissue culture plates, and cultured in RPMI supplemented with $10 \%$ fetal bovine serum and 5\% LCCM. All cultures were kept at $37^{\circ} \mathrm{C}$ in a $5 \% \mathrm{CO}_{2}$ air atmosphere.

Dehydrated bakers yeast [Saccharomyces cerevisiae] were suspended in PBS, autoclaved, and washed four times with sterile PBS by centrifugation. Prior addition to the cultures, heat killed yeast were disaggregated by passage through $26 \mathrm{G} \times 1 / 2$ in, needles.

\subsection{Preparation of the BSA:SBA-15 immunogenic complex}

Bovine serum albumin [BSA] was diluted in phosphate buffered saline [PBS] pH 7.4 was slowly added to the SBA-15 silica [v/v] and maintained during $24 \mathrm{~h}$ at $2-8{ }^{\circ} \mathrm{C}$ until complete homogenization. Also, BSA was adsorbed in aluminum hydroxide or emulsified in Incomplete Freund adjuvant [Sigma Chemical Co.]. The $\mathrm{Al}(\mathrm{OH})_{3}$ [30 g of $\mathrm{AlNH}_{4}\left(\mathrm{SO}_{4}\right)_{2} \cdot 12 \mathrm{H}_{2} \mathrm{O} / 360 \mathrm{~mL} \mathrm{H} \mathrm{H}_{2} \mathrm{O}$ d/150 mL of $\mathrm{NaOH} 1 \mathrm{~N}$ ] was also diluted in PBS to reach final concentration.

\subsection{Analysis of the encapsulation and/or adsorption potential of the antigen}

The encapsulation and/or adsorption potential of SBA-15 silica was determined in vitro. $50 \mu \mathrm{g} / \mathrm{mL}$ of BSA was added in different proportions of SBA-15 [1:5; $1: 10 ; 1: 25]$ diluted in PBS pH 7.4 in final volume of $1 \mathrm{~mL}[\mathrm{v} / \mathrm{v}]$. Non-encapsulated proteins were separated by centrifugation at $400 \times g$ for $3 \mathrm{~min}$ at $25^{\circ} \mathrm{C}$ and the supernatant was analyzed. The estimative of BSA concentration $[\mathrm{mg} / \mathrm{mL}]$ was determined using a spectrophotometer at $\lambda=280 \mathrm{~nm}$. SBA-15 solution in PBS, was prepared as above described.

\subsection{Immunizations and antibody titration}

The genetically selected $\mathrm{H}$ and $\mathrm{L}$ mice, 2-3 months-old [3-5 animals/group], were immunized with $10 \mu \mathrm{g} /$ animal of BSA in SBA-15, or adsorbed on $\mathrm{Al}(\mathrm{OH})_{3}$, by the intramuscular [IM - $50 \mu \mathrm{L}$ in each sites] or oral [OR] routes in a final volume of $0.2 \mathrm{~mL}$. The $\mathrm{H}_{\text {III }}$ and $\mathrm{L}_{\text {III }}$ mice received a second immunization IM of $10 \mu \mathrm{g} / 0.2 \mathrm{~mL}$ of BSA in SBA-15. It must be stressed that local tissue damage was not evoked and no granulomas formation was observed when SBA-15 is administered. Groups were also immunized IM with BSA emulsified in IFA. Blood samples were collected at different periods through the retro-orbital venous plexus and the individual serum samples stored at $-20^{\circ} \mathrm{C}$.

Levels of IgG anti-BSA, as well as the $\operatorname{IgG} 1$ and $\operatorname{IgG} 2 \mathrm{a}$ isotypes, were determined by ELISA [22]. Briefly, 96-well microplates [Costar] were coated with $10 \mu \mathrm{g} / \mathrm{mL}$ BSA [Sigma] diluted $100 \mu \mathrm{L} /$ well of $0.1 \mathrm{M} \mathrm{NaHCO}_{3}{ }^{-} \mathrm{pH} 9.6$ and incubated overnight 
(A)

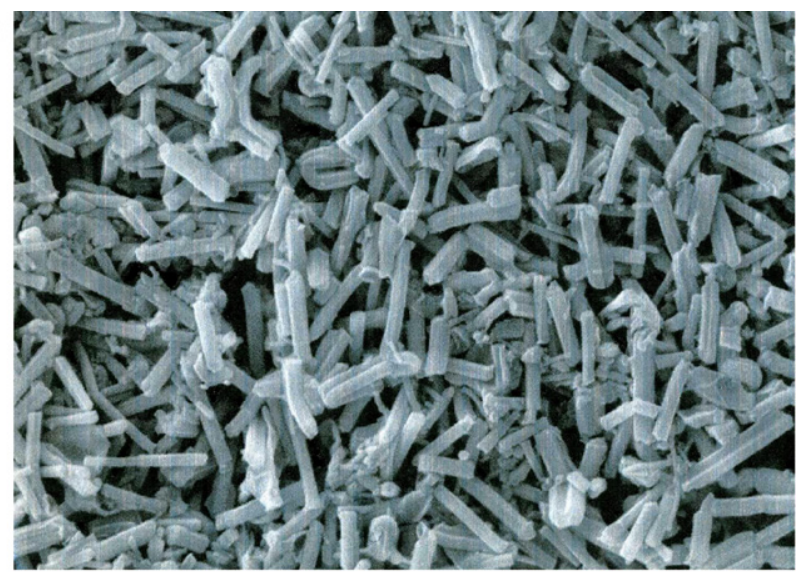

(B)

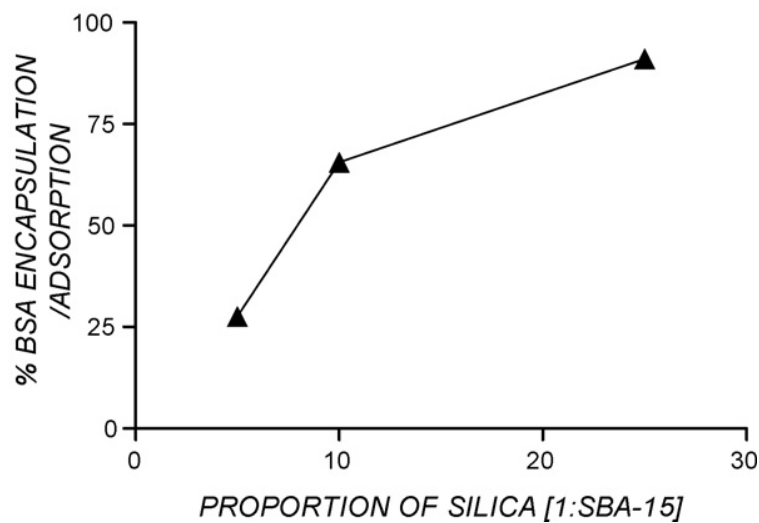
Fig. 1. (A) Characterization of SBA-15 by scanning electron microscopy [SEM]. (B)
Percentage of adsorption and/or encapsulation of BSA in SBA-15.

at $4{ }^{\circ} \mathrm{C}$. The plates were washed three times with PBS containing $0.05 \%$ Tween 20 [PBS-T] and blocked for $1 \mathrm{~h}$ at $37^{\circ} \mathrm{C}$ with $200 \mu \mathrm{L}$ of $0.01 \%$ gelatin-PBS-T. Double serial dilutions of serum samples were added and incubated for $1 \mathrm{~h}$ at $37^{\circ} \mathrm{C}$ and washed three times with PBS-T. After this period, $50 \mu \mathrm{L}$ of peroxidaselabeled anti-mouse IgG [1:2500], IgG1 [1:1000] or IgG2a [1:1000] diluted in PBS-T was added to each well and plates were incubated for $1 \mathrm{~h}$ at $37^{\circ} \mathrm{C}$. After washing, $100 \mu \mathrm{L}$ of freshly substrate solution [containing $0.5 \mathrm{mg} / \mathrm{mL}$ o-phenylenediamine, Sigma, and $0.03 \% \mathrm{H}_{2} \mathrm{O}_{2}$ in citrate/phosphate buffer at $\mathrm{pH}$ 4.9] was added to each well, and the plates were then incubated at $37^{\circ} \mathrm{C}$ for $10 \mathrm{~min}$ and the reaction was stopped with $50 \mu \mathrm{L}$ of $0.2 \mathrm{M}$ citric acid. Absorbance was measured at $\lambda=405 \mathrm{~nm}$ and the individual antibody titers expressed as $\left[\log _{2}[\bar{x} \pm \mathrm{SD}]\right]$, calculated as the reciprocal serum dilution giving an absorbance of $20 \%$ of the plateau value.

\subsection{Effect of SBA-15 on the macrophage phagocytic activity}

BMM $\phi$ cultures on coverslips were incubated for $1 \mathrm{~h}$ with different concentrations of SBA-15 varying from $20 ; 50 ; 100 ; 200$; 500 or $1000 \mu \mathrm{g} / \mathrm{mL}$. Subsequently, the cells were kept for $1 \mathrm{~h}$ at $37{ }^{\circ} \mathrm{C}$ in $5 \% \mathrm{CO}_{2}$ atmosphere with Saccharomyces cerevisiae at multiplicities of 3 yeast cells/M $\phi$ in RPMI medium containing 10\% SBF. After incubation, the cells were washed twice with Hanks medium to remove the free yeast. After $1,24,48$ and $72 \mathrm{~h}$ of incubation, the cells were washed and fixed with methanol [Merck], stained with May-Grünwald and Giemsa and analyzed by light microscopy. The control group was kept with yeasts only. Cells were counted at a magnification of $1000 \times$ with an oil immersion
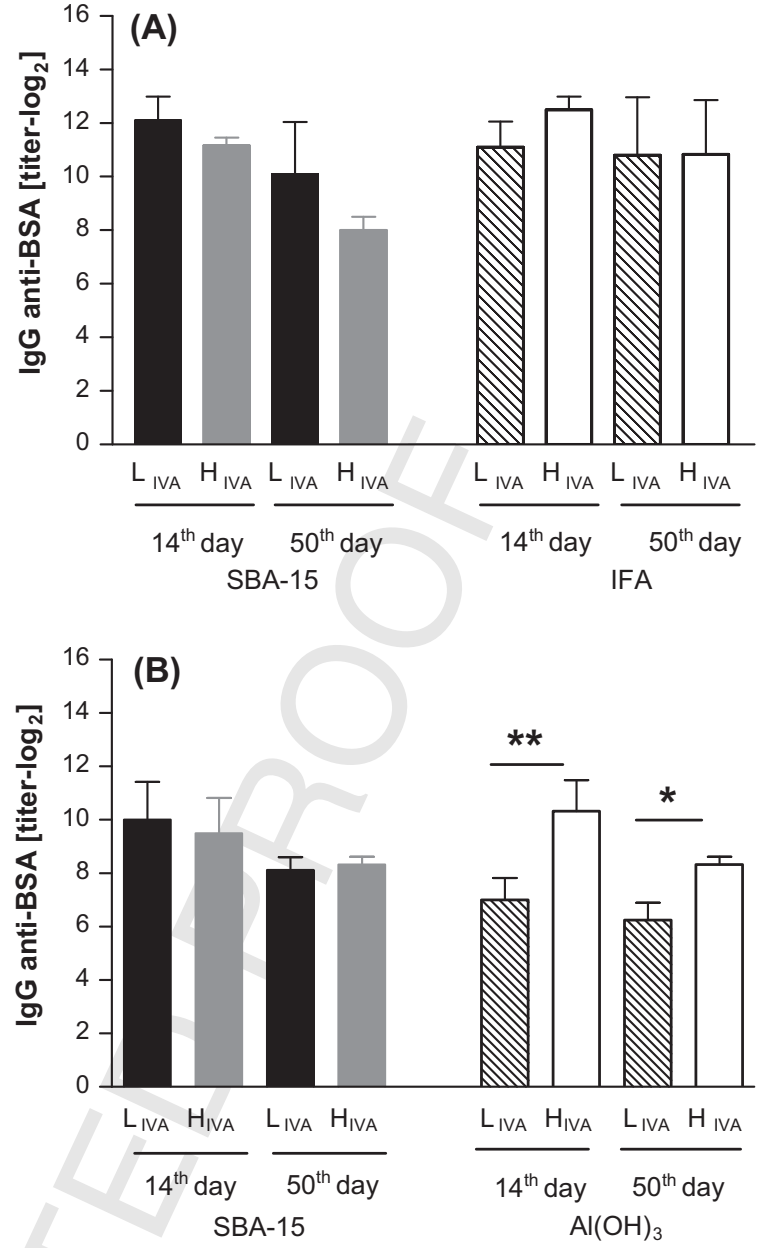

Fig. 2. Anti-BSA IgG antibody production by genetically selected mice for High $\left[\mathrm{H}_{\mathrm{IVA}}\right]$ or Low $\left[\mathrm{L}_{\mathrm{IVA}}\right]$ [ $n=4-5 /$ group] antibody response of Selection IVA. (A) Immunization by the intramuscular route with $10 \mu \mathrm{g}$ of BSA encapsulated/ads6rbed in $250 \mu \mathrm{g}$ of SBA-15 or emulsified on IFA [v/v]. (B) Oral immunization with $10 \mu \mathrm{g}$ of BSA encapsulated/adsorbed in $250 \mu \mathrm{g}$ of SBA-Y 5 or adsorbed on $250 \mu \mathrm{g}$ of $\mathrm{Al}(\mathrm{OH})_{3}$. Antibodies were measured by isotype-specific ELISA in the serum at 14 and 50 days after immunization. ${ }^{*} p<0.05,{ }^{* *} p<0.001$ [unpaired $t$-test analysis]. Results are representative of 3 independents experiments.

phase contrast objective. At least $200 \mathrm{BMM} \phi$ were scored/coverslip, with frequent focusing. The following were estimated: $a$ a) the percentage of infected cells; (b) the number of yeast internalized per macrophages. Each experiment was performed with triplicate sets of wells. All values are the averages of the triplicates from one representative experiment out of two or more performed. The cell viability was determined with the propidium iodide [PI] staining and carried out after $24 \mathrm{~h}$ of incubation with different concentrations of SBA-15 [50,100, 200, $1500 \mu \mathrm{g} / \mathrm{mL}]$. Binding of PI was used to differentiate viable and necrotic cells by flow cytometry. BMM $\phi$ [ $3 \times 10^{5}$ cells $/ \mathrm{mL}$ ] were cultured in $1 \mathrm{~mL}$ of RPMI 1640 medium supplemented with 5\% FBS containing different concentrations of SBA-15 [50,100, 200, $1500 \mu \mathrm{g} / \mathrm{mL}]$ for $24 \mathrm{~h}$. After incubation, the cells were incubated with PI as recommended by manufacturer [R\&D Systems Inc.] and analyzed in a FACSCalibur [CellQuest software] cell cytometer [BD Biosciences].

\subsection{Statistical analysis}

The results were expressed as mean $[\bar{x}] \pm$ standard deviation [S.D.] and statistical significance was set at $p<0.05$ by the Student's t-test. 

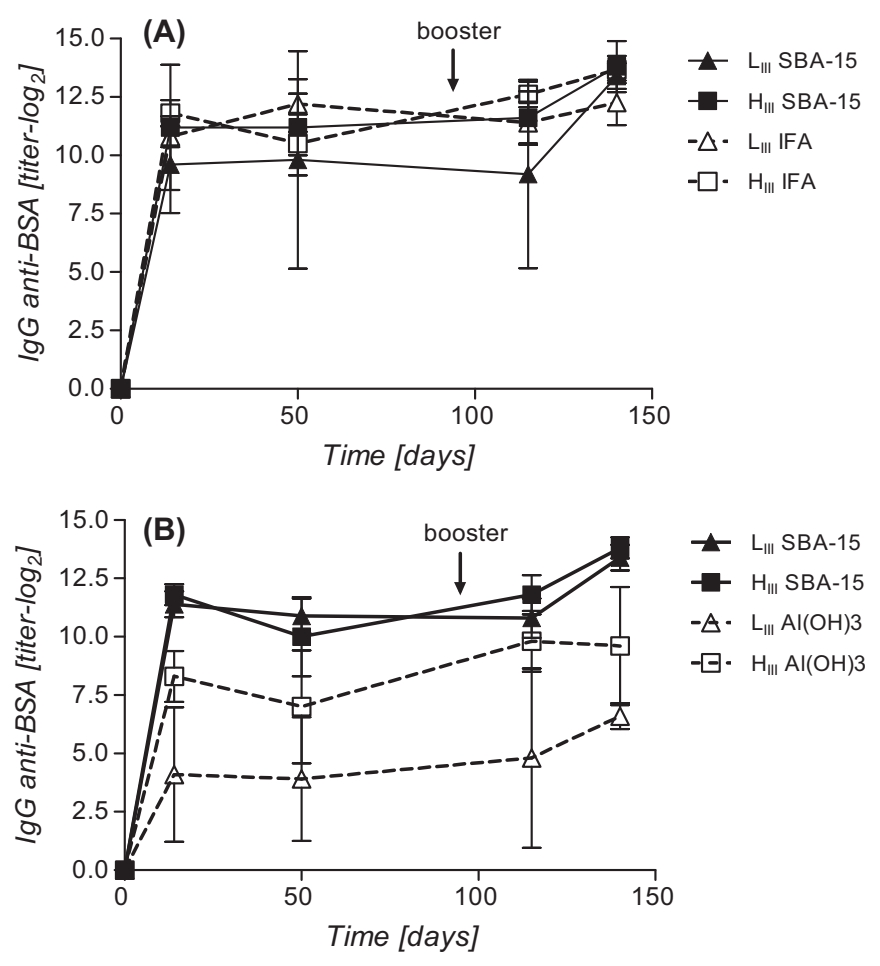

Fig. 3. Anti-BSA IgG antibody production by mice genetically selected for High $\left[\mathrm{H}_{\mathrm{III}}\right]$ or Low [ $\left.\mathrm{L}_{\text {III }}\right][n=5 /$ group] antibody response of Selection III. A. Immunization by the intramuscular route with $10 \mu \mathrm{g}$ of BSA encapsulated/adsorbed in $250 \mu \mathrm{g}$ of SBA-15 or emulsified on IFA [v/v]. B. Oral immunization with $10 \mu \mathrm{g}$ of BSA encapsulated/adsorbed in $250 \mu \mathrm{g}$ of SBA-15 or on $250 \mu \mathrm{g}$ of $\mathrm{Al}(\mathrm{OH})_{3}$. In both routes, second immunization was achieved with $10 \mu \mathrm{g} / \mathrm{animal}$, in a final volume of $0.2 \mathrm{~mL}$ of BSA, in SBA-15 by the intramuscular route at 95 th day. Antibodies were measured by isotype-specific ELISA in the serum at 14, 50, 115 and 140 days after immunization. ${ }^{*} p<0.05,{ }^{* *} p<0.001$ [unpaired $t$-test analysis]. Results are representative of 2 independents experiments.

\section{$232 \quad 3$. Results}

\subsection{Potential of adsorption and/or encapsulation of the SBA-15}

The influence of physical and structural properties of SBA15 on its adjuvant effect was determined. Under the scanning electron microscopy [SEM], a spatial distribution of silica cylinders around $2 \mu \mathrm{m}$ long are seen. They are formed internally by hexagonally ordered mesopores [mean diameter of $10 \mathrm{~nm}$ ]. The cylinders appear entangled, as shown in Fig. 1A, through a complementary and large porosity which allows the adsorption and/or encapsulation of antigens outside and inside of them. The diameter of the ordered pores inside the cylinders is between 10 and $12 \mathrm{~nm}$ [11] and the ordered porous structure can encapsulate BSA molecules [ $14 \mathrm{~nm} \times 4 \mathrm{~nm} \times 4 \mathrm{~nm}$ ], as demonstrated by other authors [23]. Our nitrogen sorption results (Mariano et al., in preparation) also revealed that a pristine SBA-15 sample has a surface area of $668 \mathrm{~m}^{2} / \mathrm{g}$ and total pore volume of $1.0 \mathrm{~cm}^{3} / \mathrm{g}$, while the adjuvant embedded with BSA has the surface area decreased to $135 \mathrm{~m}^{2} / \mathrm{g}$ and total pore volume to $0.3 \mathrm{~cm}^{3} / \mathrm{g}$.

The adjuvant effect of SBA-15 seems to be connected with the ratio adsorption/encapsulation of antigens; at 1:25 [BSA:SBA$15]$, the amount of the antigen adsorbed and/or encapsulated was approximately $91 \%$ (Fig. 1B).

\subsection{Effect of SBA-15 on modulation of the antibody response}

In order to evaluate the capacity of the SBA-15 in inducing immuneresponsiveness, the $\mathrm{L}_{\mathrm{IVA}}$ and $\mathrm{H}_{\mathrm{IVA}}$ mouse lines were immu-
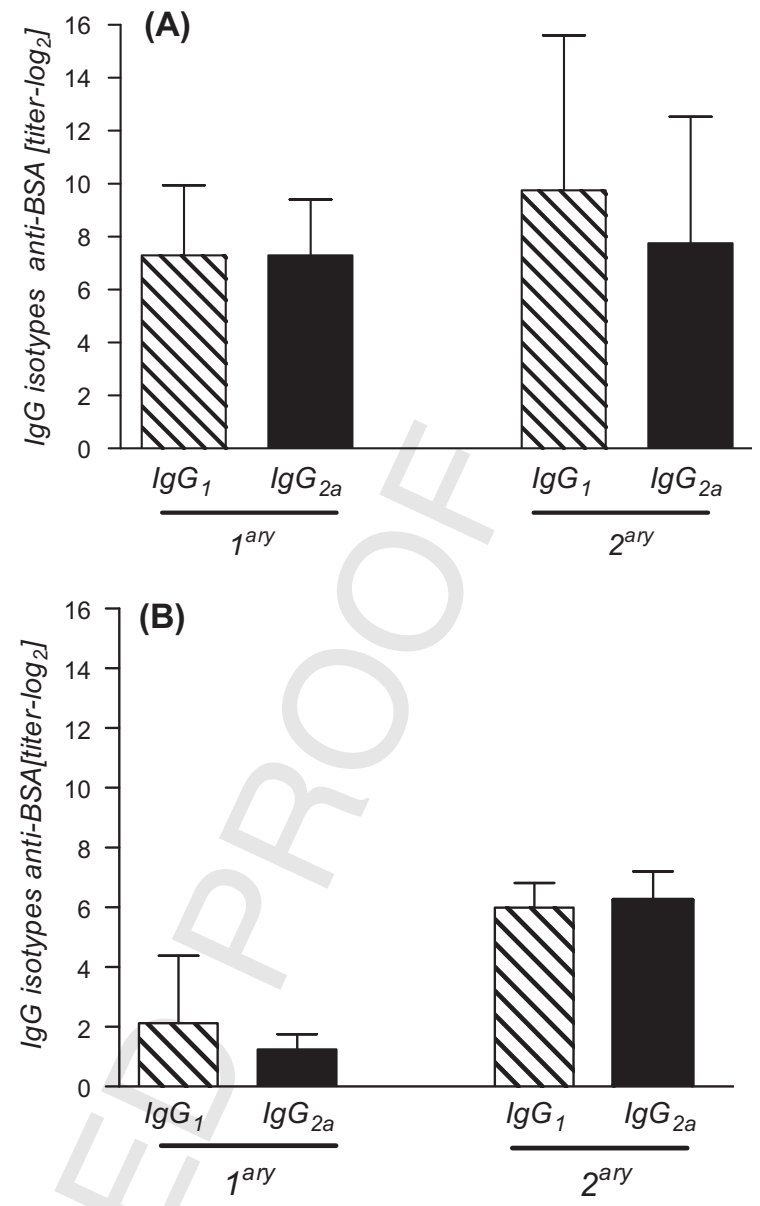

Fig. 4. Titers of IgG1 and IgG2a anti-BSA produced by $\mathrm{L}_{\mathrm{IVA}}$ mice. (A) Immunization with $10 \mu \mathrm{g}$ BSA in $250 \mu \mathrm{g}$ of SBA-15 [v/v] by the intramusculaf Poute. (B) Immunization by the oral via with $10 \mu \mathrm{g}$ BSA in $250 \mu \mathrm{g}$ of SBA-15 [v/v]. Antibocies were measured by ELISA at 50th day of the primary response and at 30th day of the secondary response.

nized with BSA encapsulated/adsorbed in SBA-15. This adjuvant effect was compared to those of $\mathrm{Al}(\mathrm{OH})_{3}$ or IFA. By the intramuscular route and after 14th day of immunization, SBA-15 silica was competent to improve and positively modulated the anti-BSA antibody responsiveness elicited by the low antibody responder mice, whereas induced similar antibodies titers in the high responders and this profile was kept up to 50th day. No significant differences between SBA-15 and IFA were observed (Fig. 2A). Similarly to the intramuscular route, oral immunization of BSA in SBA-15 in LIVA mice elicited comparable specific serum IgG levels to that obtained in the $\mathrm{H}_{\text {IVA }}$ mice (Fig. 2B). However, anti-BSA IgG levels of $\mathrm{L}_{\mathrm{IVA}}$ mice immunized with $\mathrm{BSA}$ in $\mathrm{Al}(\mathrm{OH})_{3}$ were approximately 16-fold lower $\left({ }^{* *} p<0.001\right)$ than the $\mathrm{H}_{\text {IVA }}$ mice at day 14 and 4 -fold lower in the latter response $\left({ }^{*} p<0.05\right)$ (Fig. $2 \mathrm{~B}$ ). In both routes, inoculation of BSA in PBS elicited only basal antibody levels, thus lower than those observed in SBA-15, IFA and $\mathrm{Al}(\mathrm{OH})_{3}$ immunized mice groups [data not shown].

Since SBA-15 was able to accurate the antibody responsiveness of the constitutively low responder mice eliminating the $\mathrm{H}-\mathrm{L}$ interline difference in genetic Selection IVA, the effect of SBA-15 was tested on $\mathrm{L}_{\mathrm{III}}$ and $\mathrm{H}_{\mathrm{III}}$ mice from another independent genetic Selection III that present intrinsic genetic modifications of their lymphocyte potentialities. As occurred in Selection IVA, the SBA-15 positively modulated the immune response of $\mathrm{L}_{\text {III }}$ mice that became competent responder presenting similar antibodies levels as the $\mathrm{H}_{\text {III }}$ mice. Fig. $3 \mathrm{~A}$ illustrates the primary and secondary anti-BSA IgG 
(A)

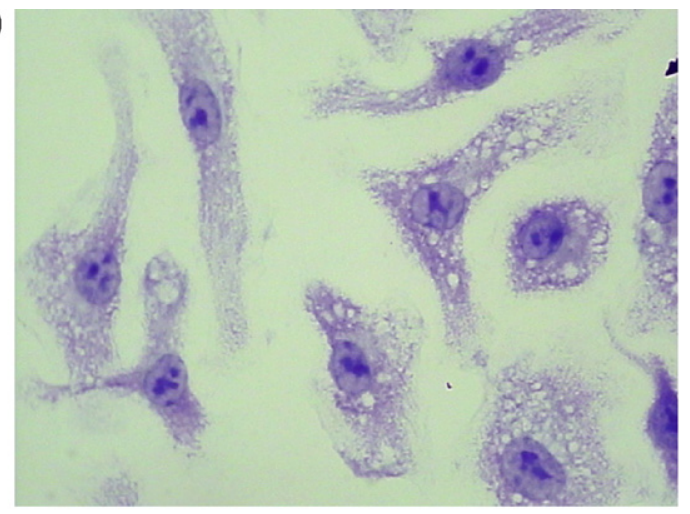

(C)

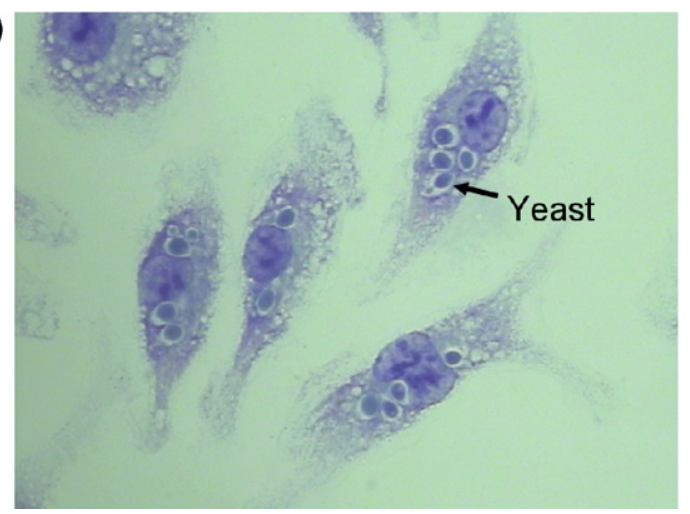

(B)

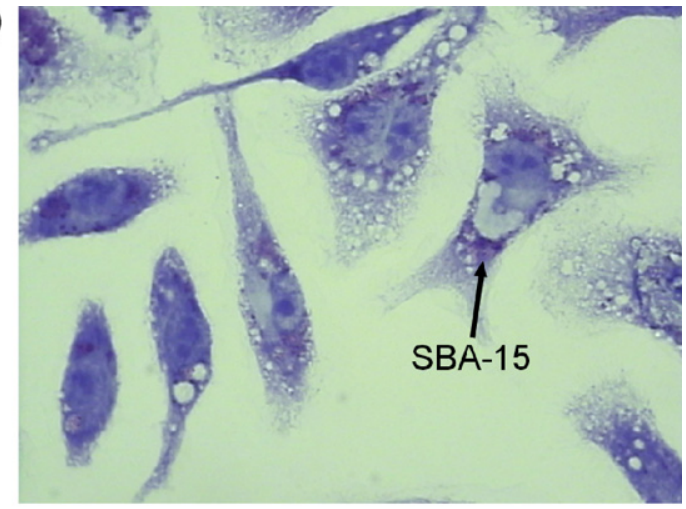

(D)

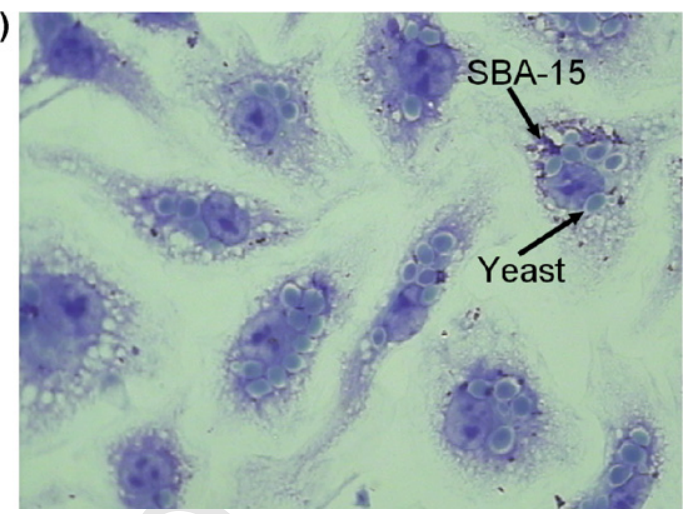

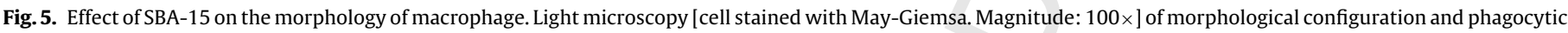
activity of $\mathrm{L}_{\text {III }}$ mice bone marrow macrophages after $24 \mathrm{~h}$. [A] M $\phi ;$ [B] M $\phi+100 \mu \mathrm{g} / \mathrm{mL} \mathrm{SBA}-15$; [C] M $\phi+$ yeast; [D] M $\phi+$ yeast $+100 \mu \mathrm{g} / \mathrm{mL}$ SBA-15.

antibody response elicited by the intramuscular administration of SBA-15 or IFA and no significant differences on the antibody titers were observed between $\mathrm{L}_{\text {III }}$ and $\mathrm{H}_{\text {III }}$ mice. As for Selection IVA, animals that received BSA in PBS showed basal immunoglobulin levels [data not shown].

Anti-BSA responses were also evaluated in $\mathrm{L}_{\mathrm{III}}$ and $\mathrm{H}_{\mathrm{III}}$ mice immunized by the oral route with the antigen in $\mathrm{SBA}-15$ or $\mathrm{Al}(\mathrm{OH})_{3}$. The IgG antibody titers produced by $\mathrm{L}_{\text {III }}$ mice immunized with SBA15 were analogous to those of the high responder line (Fig. 3B). In contrast, $\mathrm{Al}(\mathrm{OH})_{3}$ was unable to enhance humoral response in $\mathrm{L}_{\mathrm{III}}$ mice. At 14 days post-immunization the $\mathrm{L}_{\mathrm{III}}$ mice presented specific IgG titers approximately $4 \log _{2}$ lower than those produced by $\mathrm{H}_{\text {III }}$ mice and these differences were 256 -fold lower after booster (Fig. 3B).

To determine whether the SBA-15 administration evokes preferential activation of $\mathrm{T}_{\mathrm{H}} 1$ or $\mathrm{T}_{\mathrm{H}} 2$ response, the IgG isotypes, IgG2a and $\operatorname{IgG} 1$, in the primary and secondary responses were evaluated. At 50 days post-primary and 30 days post-secondary vaccination, $\mathrm{L}_{\text {IVA }}$ mice [ $n=4 /$ group] orally immunized with $10 \mu \mathrm{g}$ of BSA in $250 \mu \mathrm{g} \mathrm{SBA}-15$ (Fig. 4A) or intramuscularly (Fig. 4B) produced both IgG1 and IgG2a anti-BSA at similar levels. These findings were confirmed during responses to other orally administered immunogens, such as human gamma-globulin, Hepatitis A or B vaccines, in isogenic $B A L B / C$ and outbred Swiss mouse lines. Oral immunization in $B A L B / c$ mice with human gamma-globulin, Hepatitis A vaccines adsorbed in SBA-15 showed an increase in secretory Immunoglobulin A [2 or 8-fold, respectively] and serum Immunoglobulin G [16 or 2-fold, respectively] production compared with the group immunized with the soluble antigens (Scaramuzzi et al., in preparation).

\subsection{Effect of SBA-15 on morphology and phagocytic activity of macrophage}

To elucidate the mechanism of equivalent induction of antibody production by the SBA-15 adjuvant, the morphology and phagocytic activity of Swiss or $\mathrm{L}_{\text {III }}$ or $\mathrm{L}_{\text {IVA }}$ mice $\mathrm{M} \phi$ were evaluated by in vitro assays. Increased concentrations [20,50 or $100 \mu \mathrm{g} / \mathrm{mL}]$ of these nanoparticles did not affect the morphology of macrophages from $\mathrm{L}_{\mathrm{III}}$ (Fig. 5), Swiss or $\mathrm{L}_{\mathrm{IVA}}$ mice lines [data not shown]. Cell integrity was maintained up to $96 \mathrm{~h}$ at various concentrations of SBA-15 [200-1000 $\mu \mathrm{g} / \mathrm{mL}]$ and PI assays were performed confirming the non-toxicity of this new adjuvant. In addition, higher concentrations of SBA-15 did not alter the cells integrity. Although not modifying the phagocytic activity of macrophages, higher concentrations of silica $[1.5-5 \mathrm{mg} / \mathrm{mL}]$ reduced the viability of these cell types. It must be emphasize that the general in vivo non-toxic property of these nanoparticles was ascertained during a one year experiment, by administering $250 \mu \mathrm{g}$ in a group of 15 Swiss 2month-old mice and measuring weekly their weight and evaluating their morphological aspects; no differences of growth or weight were observed in these SBA-15 treated animals when compared with 10 control Swiss mice that received phosphate-buffer saline [data not shown].

The phagocytic potential and the percentage of $S$. cerevisiae infected $M \phi$ from $\mathrm{L}_{\mathrm{III}}$ and Swiss lines, incubated with 200,500 or $1000 \mu \mathrm{g} / \mathrm{mL}$ of SBA-15 for $1 \mathrm{~h}$, were similar to the control group. In $\mathrm{L}_{\text {III }}$ macrophages this profile was maintained up to $24 \mathrm{~h}$ of incubation, however after 48 and $72 \mathrm{~h}$ the percentage of infection was reduced in treated groups, decreasing $15 \%$ as compared with the control group (Fig. 6A). Swiss mice M $\phi$ treated with 200,500 or 

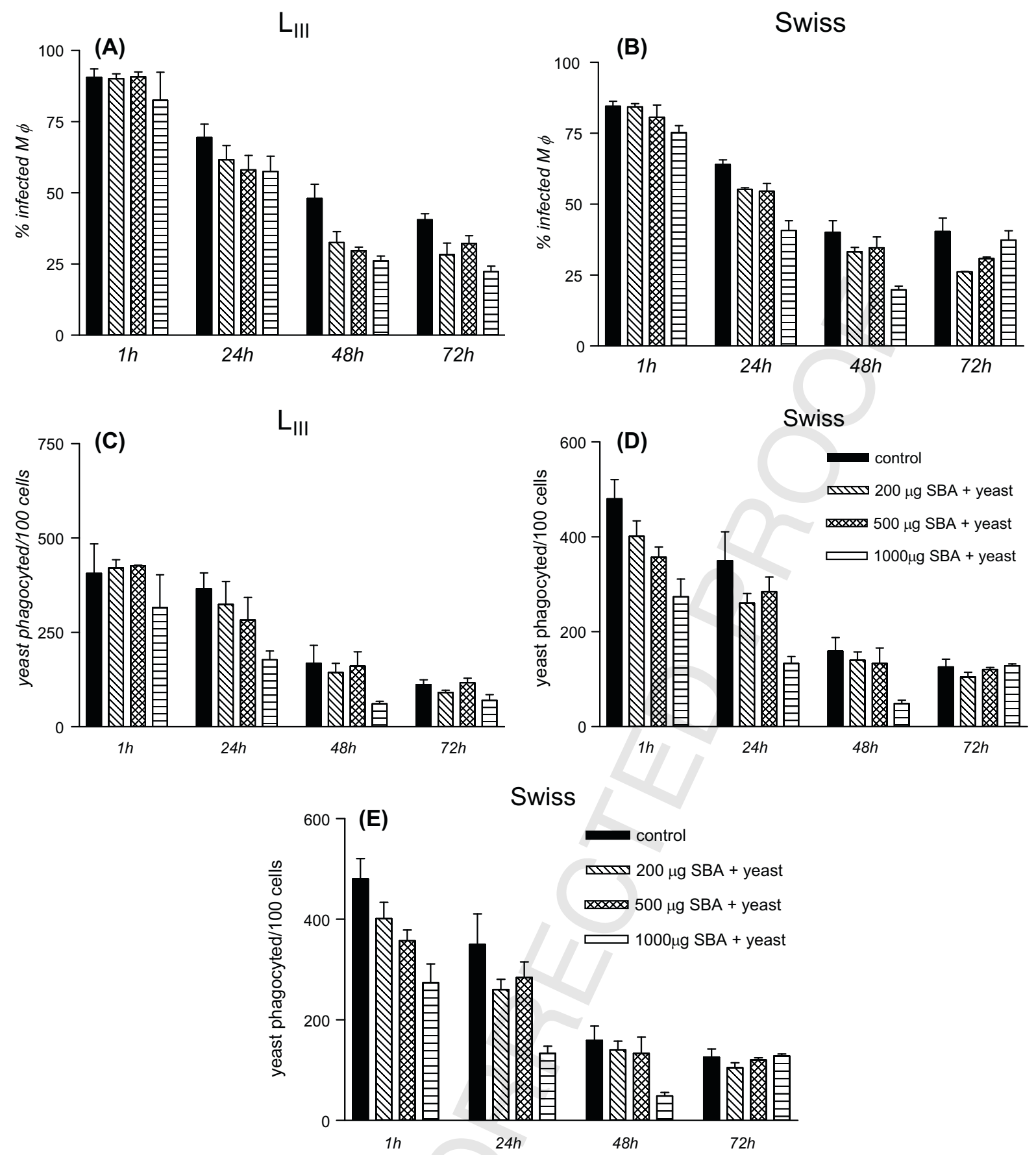

Fig. 6. Effect of SBA-15 on the phagocytic and catabolism activity of $\mathrm{L}_{\mathrm{III}}$ and Swiss BMM $\phi$. Percentage of macrophages infected after $1-72 \mathrm{~h}$ of incubation with different concentrations of SBA-15 [200-1000 $\mu \mathrm{g} / \mathrm{mL}]+$ yeasts or only yeast [control group] in $\mathrm{L}_{\mathrm{II}}$ mice [A] or Swiss mice [B]. Number of yeasts phagocyted after 1-72 $\mathrm{h}$ of incubation with diverse concentrations of SBA- 15 [200-1000 $\mu \mathrm{g} / \mathrm{mL}$ ] yeasts or only yeast [control group] in $\mathrm{L}_{\text {III }}$ mice [C] or Swiss mice [D]. The $\mathrm{L}_{\text {III }}$ and Swiss macrophages results are representative of phagocytic activity of $\mathrm{L}_{\mathrm{IVA}}$ mice and of two independent experiments in triplicate.

$1000 \mu \mathrm{g} / \mathrm{mL}$ of SBA-15 for $24 \mathrm{~h}$, the percentage of infected cells decrease $9-23 \%$, contrasting with the control group. After $48 \mathrm{~h}$, the difference was of $\sim 20 \%$ only for the group treated with $1000 \mu \mathrm{g} / \mathrm{mL}$; at $72 \mathrm{~h}$, no distinction was observed (Fig. 6B).

Catabolism was also verified by monitoring the number of yeasts/BMM $\phi$ up to $72 \mathrm{~h}$ of infection. The number of yeasts per cell in $\mathrm{L}_{\mathrm{III}}$ and Swiss cultures treated with diverse silica concentrations decreased as much as in the control group and no inter-group differences were observed (Fig. 6C and D).

\section{Discussion}

The success of a vaccination is measured by the specificity, magnitude and duration of the protective immunity. Vaccines that contain attenuated pathogens normally do not require adjuvants because they mimic natural infection that, in fact, is the better vaccination process. However, recombinant vaccines often need the addition of exogenous adjuvants to induce potent and persistent immune responses. The role played by particulate antigens 
delivery depends on the mediation of the effective uptake by APC that have critical importance on the transport of antigens from the periphery to the main organized lymphoid organs [24-26]. Thus, co-delivery of associated or entrapped adjuvant and antigen is a possible path for the enhanced potential of particle-based liberation systems, with the main emphasis on improving liposomal and biodegradable polymer-based vehicles.

Adsorption and encapsulation of antigens by polymers helps to avoid the exposure of immunogens to organic solvents, high shear stresses and to low $\mathrm{pH}$ [27]. Briefly, after immunization, the degree of antigen adsorption and/or encapsulation can be modified due to interaction with components of the interstitial fluids. Moreover, previously reported articles highlighted the direct relationship between the percentage of encapsulated antigens and it continuous and/or directed the release by stimulation of the immune system [28]. Our results demonstrated that SBA-15 was able to adsorb and/or encapsulate diverse natural antigens and, probably, enhance the immunity, here represented by the anti-BSA responsiveness (Figs. 1-3). Optimal proportions of adsorption/encapsulation of antigen in silica seem to be related to the physic-chemistry attributes of the immunogens. A series of studies on these physicochemical characteristics is the purpose of another paper (Mariano et al., in preparation).

The results obtained through phagocytosis assays showed that the SBA-15 was engulfed by macrophages (Figs. 5 and 6) and these data are supported by the literature data [29]. Moreover, those reports demonstrated that the phagocytosis of silica particles, by macrophages, induces the generation of reactive oxygen species in these cells and induces the production of IL-1 $\beta$ in a caspase- 1 dependent way via the activation of NALP3 inflamasome [30,31]. Besides, for preliminary data concerning the interaction of SBA-15 and macrophages, further analysis about cytokine production and by antigen presenting cells will clarify mechanisms involving the immunogenicity improvement of the SBA-15 particles.

In 1987, it was clearly demonstrated that the in vivo administration of colloidal silica strongly increases antibody responsiveness in the genetically selected LIVA mice, whereas this does not occur in the $\mathrm{L}_{\text {III }}$ ones [18]. In the former, the higher catabolic M $\phi$ activity restrain the lymphocytes stimulation being responsible for the weak and transient antibody response of $\mathrm{L}_{\mathrm{IVA}}$ animals, whereas the persistent immunogenic stimulation is responsible for the strong and long-lasting response of the $H_{\text {IVA }}$ mice line $[14,15]$. Thus, the minimum amount of antigens expressed in the surface of macrophages in low mice generates a non-effective activation of $\mathrm{T}$ lymphocytes resulting in a poor antibody production. In fact, this trait must be quite naturally frequent in human and other species. Data in Figs. 2 and 3 support that immunization by the intramuscular route with BSA encapsulated/adsorbed in SBA-15 or emulsified on the IFA were able to eliminate the $\mathrm{H}$-L interlines phenotypic differences in both Selections III and IVA. Concerning to the adequacy of the adjuvant, it is important to remind that oily substances, like IFA, provokes lumps under the skin, while the soluble silica solution is easily absorbed by the muscles. It is noteworthy that the volume used in immunization by intramuscular injection does not avoid muscle damage and any immune bias due to cell necrosis for instance.

By the oral via, the results ascertained that $\mathrm{Al}(\mathrm{OH})_{3}$, the most used adjuvant in human vaccination, is not efficient in providing an efficacious mucosal immune response. Furthermore, it was unable to positively modulate the antibody responsiveness of the low antibody responder individuals (Figs. 2 and 3). Conversely, the positive modulation of the humoral response observed in L mouse lines suggests that antigen encapsulation/absorption in SBA-15 could guarantee a better epitopic recognition by the APC, promoting a successful activation of the immune system. Although no other mucosal adjuvant was compared with the nanostructured silica, differences between $\mathrm{Al}(\mathrm{OH})_{3}$ and SBA-15 indicate that the ordered mesoporous particles is an efficient adjuvant in inducing competent immunity. The SBA-15 physicochemical characteristics possibly will prevent the antigen degradation by the stomach acid when administered by the oral route. In addition, supported by the high titers of protective serum and secretory antibodies, the augmented numbers of $\mathrm{T}$ and specially B lymphocytes observed at Peyer's patches and mesenteric lymphonodes from BALB/c mice immunized with Hepatitis A vaccine or human gamma-globulin on SBA-15 indicated that there were proliferation and recruitment of immunocompetent cells, as well as the enhancement of the immune response, after the employment of these nanoparticles as an oral adjuvant (Scaramuzzi et al., in preparation).

Upon interaction with cognate antigen presented by antigenpresenting cells, $\mathrm{CD}^{+} \mathrm{T}$ cells can differentiate into a variety of effector subsets, including classical $\mathrm{T}_{\mathrm{H}} 1$ and $\mathrm{T}_{\mathrm{H}} 2$ cells and the more recently defined $T_{H} 17$ cells. The $T_{H} 1$ immune response is attended by IL- 2 and IFN- $\gamma$ secretion, leading to cell-mediated immune response and expressed by complement-fixing murine IgG2a, IgG2b and IgG3 isotypes. Conversely, the $\mathrm{T}_{\mathrm{H}} 2$ cell mediated response is associated with expression of IL-4, IL-5 and IL-13, and the IgG1, IgA and IgE antibodies in mice. $\mathrm{T}_{\mathrm{H}} 17$ cells produce IL-17, IL-17F and IL-22 and play important roles in clearance of extracellular bacteria and fungi, especially at mucosal surfaces, and in autoimmune processes [32-34]. The complex immune network involving distinct immunocompetent cells, including the $\mathrm{T}_{\mathrm{H}} 1$ and $\mathrm{T}_{\mathrm{H}} 2$ lymphocytes, is essentially pleiotropic and the interactions between the innate and the acquired functions ensure the multidirectional protection of a natural population to infectious agents and chronic-degenerative diseases. Thus, the controls of the variety of responses are multi-factorial and include the genetic constitution of the population and the distinct environmental aspects including the antigen nature and dose.

Among the environmental factors it must be included the adjuvants, a relevant statement usually neglected. These compounds exert a strong influence on the type of immune response and many adjuvants, including complete Freund's adjuvant, saponincontaining adjuvants and immune-stimulating complexes induce either a mixed or a $\mathrm{T}_{\mathrm{H}} 1$-partial response, whereas, aluminum salts selectively stimulate a $\mathrm{T}_{\mathrm{H}} 2$ immune response [32,35]. Here, the results proved that the ordered nanostructured SBA-15 induced co-production of IgG2a and IgG1 isotypes in mice (Fig. 4A and B).

Finally, contrasting with other studies, the adjuvant effectiveness of the non-toxic SBA-15 nanoparticles was ascertained in distinct mouse lines, not only the common worldwide employed isogenic lines, each one representing a single individual. In this study, the use of the outbred genetically selected $\mathrm{H}$ and L mice, mainly the low responder individuals, establish a new perspective since it proved possibly the improvement of immuneresponsiveness to vaccines in a natural population.

\section{Acknowledgments}

This work was supported by funds from the INCTTOX Program of Conselho Nacional de Pesquisa, Brazil [CNPq] and Fundação de Amparo a Pesquisa do Estado de Sao Paulo, Brazil [FAPESP] and Cristália Pharmaceutics. D. V. Tambourgi, M.C.A. Fantini and O.A. Sant'Anna are Researchers of CNPq-Brazil.

\section{References}

[1] Degen WG, Jansen T, Schijns VE. Vaccine adjuvant technology: from mechanistic concepts to practical applications. Expert Rev Vaccines 2003;2(2):327-35.

[2] Edelman R. The development and use of vaccine adjuvants. Mol Biotechnol 2002;21(2):129-48.

[3] McCluskie MJ, Weeratna RD. Novel adjuvant systems. Curr Drug Targets Infect Disord 2001;1(3):263-71. 
4] Bueno Da Costa MH, Quintilio W, Tanizaki MM, Sant'Anna OA, Schwendener RA, de Araujo PS. Heat shock protein micro-encapsulation as a double tool for the improvement of new generation vaccines. J Liposome Res 2002;12(1-2):29-35.

[5] Waite DC, Jacobson EW, Ennis FA, Edelman R, White B, Kammer R, et al. Three double-blind, randomized trials evaluating the safety and tolerance of different formulations of the saponin adjuvant QS-21. Vaccine 2001;19(28-29):3957-67.

[6] Marchand M, Punt CJ, Aamdal S, Escudier B, Kruit WH, Keilholz U, et al. Immunisation of metastatic cancer patients with MAGE-3 protein combined with adjuvant SBAS-2: a clinical report. Eur J Cancer 2003;39(1):70-7.

[7] Ulmer JB, Valley U, Rappuoli R. Vaccine manufacturing: challenges and solutions. Nat Biotechnol 2006;24(11):1377-83.

[8] Glenny AT, Buttle GAH, Steven MF. Rate of disappearance of diphtheria toxoid injected into rabbits and guinea-pigs: toxoid precipitated with alum. J Pathol 1931;34(1):267-75.

[9] Zhao D, Feng J, Huo Q, Melosh N, Fredrickson GH, Chmelka BF, et al. Triblock copolymer syntheses of mesoporous silica with periodic 50 to 300 angstrom pores. Science 1998;279(5350):548-52.

[10] Zhao D, Hou Q, Feng J, Chmelka BF, Stucky GD. Nanionic triblock and star diblock copolymer and surfactant syntheses of highly ordered, hydrothermally stable, mesoporous silica structures. J Am Chem S6C 1998;120(24):6024-36.

[11] Matos JR, Mercuri LP, Kruk M, Jaroniec M. Toward the synthesis of extra-largepore MCM-41 analogues. Chem Mater 2001;13(5):1726-31.

[12] Mercuri LP, Carvalho LV, Lima FA, Quayle C, Fantini MC, Tanaka GS, et al. Ordered mesoporous silica SBA-15: a new effective adjuvant to induce antibody response. Small 2006;2(2):254-6.

[13] Cabrera WH, Ibanez OM, Oliveira SL, Sant'Anna OA, Siqueira M, Mouton D, et al. Evidence for distinct polygenic regulation of antibody responses to some unrelated antigens in lines of mice selected for high or low antibody responses to somatic antigen of Salmonella. Immunogenetics 1982;16(6):583-92.

[14] Ferreira V, Gennari M, Reis MH, Siqueira M, Stiffel C, Mouton D, et al. Potentialities of immunocompetent cells in high and low antibody-producing lines of mice obtained by selective breedings for responsiveness to flagellar or somatic antigens of Salmonellae. J Immunogenet 1985;12(6):309-19.

[15] Sant'Anna OA, Ferreira VC, Reis MH, Gennari M, Ibanez OM, Esteves MB, et al. Genetic parameters of the polygenic regulation of antibody responsiveness to flagellar and somatic antigens of salmonellae. J Immunogenet 1982;9(3):191-205.

[16] Biozzi G, Mouton D, Stiffel C, Bouthillier Y. A major role of the macrophage in quantitative genetic regulation of immunoresponsiveness and antiinfectious immunity. Adv Immunol 1984;36(1):189-234.

[17] Biozzi G, Mouton D, Sant'Anna OA, Passos HC, Gennari M, Reis MH, et al. Genetics of immunoresponsiveness to natural antigens in the mouse. Curr Top Microbiol Immunol 1979;85(1):67-98.

[18] Gennari M, Bouthillier Y, Ibanez OM, Ferreira VC, Mevel JC, Reis MH, et al. Effect of silica on the genetic regulation of antibody responsiveness. Ann Inst Pasteur Immunol 1987;138(3):359-70.
[19] Zimmerman BT, Canono BP, Campbell PA. Silica decreases phagocytosis and bactericidal activity of both macrophages and neutrophils in vitro. Immunology 1986;59(4):521-5.

[20] Fantini MCA, Matos JR, Silva LCC, Mercuri LP, Chieri GO, Celer EB, et al. Ordered mesoporous silica: microwave synthesis. Mater Sci Eng B 2004;112(2-3):106-10.

[21] Giles AR. Guidelines for the use of animals in biomedical research. Thromb Haemost 1987;58(4):1078-84

[22] Engvall E, Perlmann P. Enzyme-linked immunosorbent assay (ELISA). Quantitative assay of immunoglobulin G. Immunochemistry 1971;8(9):871-4.

[23] Song SW, Hidajat K, Kawi S. Functionalized SBA-15 materials as carriers for controlled drug delivery: influence of surface properties on matrix-drug interactions. Langmuir 2005;21(21):9568-75.

[24] Eyles JE, Carpenter ZC, Alpar HO, Williamson ED. Immunologica aspects of polymer microsphere vaccine delivery systems. J Drug Target 2003;11(8-10):509-14.

[25] Ludewig B, Barchiesi F, Pericin M, Zinkernagel RM, Hengartner H, Schwendene RA. In vivo antigen loading and activation of dendritic cells via a liposomal peptide vaccine mediates protective antiviral and anti-tumour immunity. Vaccine 2000;19(1):23-32.

[26] Zinkernagel RM, Ehl $S$, Aichele $P$, Oehen $S$, Kundig $T$, Hengartner $H$. Antigen localisation regulates immune responses in a dose- and timedependent fashion: a geographical view of immune reactivity. Immunol Rev 1997;156(1):199-209.

[27] Coombes AG, Major D, Wood JM, Hockley DJ, Minor PD, Davis SS. Resorbable lamellar particles of polylactide as adjuvants for influenza virus vaccines. Biomaterials 1998;19(11-12):1073-81.

[28] Chang M, Shi Y, Nail SL, HogenEsch H, Adams SB, White JL, et al. Degree of antigen adsorption in the vaccine or interstitial fluid and its effect on the antibody response in rabbits. Vaccine 2001;19(20-22):2884-9.

[29] Huaux F. New developments in the understanding of immunology in silicosis. Curr Opin Allergy Clin Immunol 2007:7(2):168-73.

[30] Muruve DA, Petrilli V, Zaiss AK, White LR, Clark SA, Ross PJ, et al. The inflammasome recognizes cytosolic microbial and host DNA and triggers an innate immune response. Nature 2008;452(7183):103-7.

[31] Hornung V, Bauernfeind F, Halle A, Samstad EO, Kono H, Rock KL, et al. Silica crystals and aluminum salts activate the NALP3 inflammasome through phagosomal destabilization. Nat Immunol 2008;9(8):847-56.

[32] Bomford R, Stapleton M, Winsor S, McKnight A, Andronova T. The control of the antibody isotype response to recombinant human immunodeficiency virus gp120 antigen by adjuvants. AIDS Res Hum Retroviruses 1992;8(10):1765-71.

[33] Mosmann TR, Sad S. The expanding universe of T-cell subsets: Th1, Th2 and more. Immunol Today 1996;17(3):138-46.

[34] O'Garra A. Cytokines induce the development of functionally heterogeneous T helper cell subsets. Immunity 1998;8(3):275-83.

[35] Comoy EE, Capron A, Thyphronitis G. In vivo induction of type 1 and 2 immune responses against protein antigens. Int Immunol 1997;9(4):523-31. 